\title{
FORUM
}

\section{Discussion Forum: \\ The Vanishing Nineteenth Century in European History?}

\author{
Organizers:
}

Karen Hagemann (University of North Carolina at Chapel Hill), Simone Lässig (German Historical Institute Washington, D.C)

\section{Introduction: \\ The Shifting Space of the Nineteenth Century in European History}

$\mathrm{T}$ HIS forum explores from multiple perspectives the often stated impression that the nineteenth century is "vanishing" from German and European history. It asks how one can explain this trend, what consequences it has for the development of historiography and public historical knowledge, if and why the nineteenth century matters for the present, and what the future of nineteenth-century history might be. Fourteen experts on different regions and historiographical approaches to European history from the United States and Germany discuss these questions. We sought contributors from these two countries in order to illuminate differences in the historical profession on either side of the Atlantic, and are sure that a broader regional comparison would point to more varieties in the state of historical research on the nineteenth century.

The first six contributions focus on regional historiographies. David Blackbourn and James M. Brophy discuss the situation in German Central European history. Pieter M. Judson explores the state of the history of Habsburg Central Europe. Alexander Martin looks at Russian history, Lloyd S. Kramer at French history, and Alex Chase-Levenson at British history. With this selection, we wanted to focus on the historiography of five large European nations and empires of the nineteenth century. The next five contributions focus on particular historiographic approaches or subfields of history. We decided here to combine traditional fields, such as military history and Jewish studies, with more recent approaches, such as cultural history, women's and gender history, and colonial history. Here, too, our selection does not claim to be in any way comprehensive. We could have included other important fields, e.g., political history, social history, or the history of emotions. Roger Chickering discusses the situation in military history, Simone Lässig in Jewish history, Suzanne Marchand in intellectual and cultural history, and Karen Hagemann in women's and gender history. The final three contributors offer reflections on the forum as a whole from the perspectives of their respective fields of expertise: Birgit Aschmann from European history, Jürgen Osterhammel from global history, and Andrew Zimmerman from transatlantic history.

We would like to thank David Lazar and Insa Kummer of the German Historical Institute Washington, D.C., for their help in preparing this forum for publication. 
"Honey, I Shrunk German History" was the title David Blackbourn gave to his luncheon address at the 2013 annual conference of the German Studies Association (GSA). ${ }^{1}$ In his presentation, Blackbourn eloquently described the diminished place in American scholarship of German Central Europe to which the nineteenth century had been relegated, and that it still seems to occupy. In addition to the dramatic decrease in the number of completed doctoral dissertations and advertised positions in nineteenth-century history, indicators of this trend include the century's shrinking place on the program of the GSA's annual meetingsfrom 32 percent of the papers presented in 1991, to 20 percent in 2010 and 5 percent in 2017-and in the book review section of Central European History (CEH): in 1998, 38 percent of the monographs reviewed in $C E H$ dealt with the nineteenth century. This declined to 20 percent in $2010 .^{2}$

Specialists in other branches of European history on both sides of the Atlantic have observed similar developments in their fields. They emphasize that the interplay of the distinct development of regional historiographies, field-specific factors, and external influences has determined the shifting position of the nineteenth century in European history. ${ }^{3}$ In general, as Blackbourn and James M. Brophy argue in their contributions to this forum, we as historians have to accept the obvious: "time has moved on." What we are witnessing is a pattern with a long history in our discipline. With access to new archival sources, new periods and topics become more interesting, not least to scholars at the outset of their careers. Especially important in this regard is the end of the Cold War and, with it, the increasing interest in post-1945 history. This development received an important boost from the opening of East German and Eastern European archives in the early 1990s. In several cases, archives broke with—or were forced to break with—-the usual thirty-year waiting period before making records accessible, thereby inviting historians to approach contemporary history as the direct prehistory of the present day. Furthermore, generational change in the history profession has played an important role in all fields. New cohorts of historians always want to work on new subjects. In addition, paradigm shifts and academic fashions, along with changing political landscapes and the neoliberal demand for the immediate usefulness and relevance of historical research and teaching, have had an enormous influence in all fields of European history. The move away from the nineteenth century has also been compelled by the market-driven demands of publishers and by the politics- and fashion-driven funding policies of foundations and other institutions that support research.

The decline in attention to the nineteenth century in European history has not, however, followed the same course on both sides of the Atlantic. In the field of Central European history, for example, it has been less marked in Germany than in the United States. Like its American counterpart, the German historical profession has seen a clear shift of research toward the open territory of the recent past and newly accessible archival sources. Major

\footnotetext{
${ }^{1}$ David Blackbourn, "Honey, I Shrunk German History," German Studies Association Newsletter 38, no. 2 (2013-2014): 44-53.

${ }^{2}$ Ibid., 45-48. We have no numbers for later developments.

${ }^{3}$ Suzanne Marchand, "Embarrassed by the Nineteenth Century," in Consortium on Revolutionary Europe, 1750-1850: Selected Papers 2002, ed. Bernard Cook et al. (Tallahassee, FL: Consortium on Revolutionary Europe, 2004), 1-16; Jürgen Osterhammel, "In Search of a Nineteenth Century," Sixteenth Annual Lecture of the German Historical Institute (Nov. 14, 2002), Bulletin of the German Historical Institute 32 (Spring 2003): 9-28; Till van Rahden, "Lumpen sammeln: Siegried Kracauer und die Geschichte des 19. Jahrhunderts," Historische Zeitschrift 307, no. 2 (2017): 319-40.
} 
research institutes like the Center for Contemporary History in Potsdam, founded in 1992, complement the numerous university chairs in contemporary history established in Germany since the 1990s. ${ }^{4}$ As in the case of the GSA's annual meetings, the overwhelming majority of proposals for panels at the biennial meetings (Historikertage) of Germany's historical association, the Verband der Historiker und Historikerinnen Deutschlands (VHD), deal with topics in contemporary history, but earlier periods, including the nineteenth century, are still well represented. ${ }^{5}$ The "decline" and the "crisis" of that century do not seem to have progressed as far in Germany as in the United States. Nineteenth-century history is more regularly taught at German universities, and more studies on the nineteenth century are still published, also by younger historians. Specialists in nineteenth-century history also seem to be holding their own in the competition for professional recognition. One indicator of this are the VHD's prizes for published doctoral dissertations and Habilitationsschriften. ${ }^{6}$ To be sure, works on contemporary history won the lion's share (six of eleven) of the Hedwig Hintze Prizes for published dissertations in the period 2002-2016. ${ }^{7}$ But more Carl Erdmann Prizes for Habilitationsschriften were awarded to studies on the nineteenth century (five of twelve) than to works on any other time period. ${ }^{8}$

The difference here between the United States and Germany can be attributed, in large part, to several structural factors. One important element is the more limited influence of the market on German academia. Universities are solely state-funded in Germany, and history is still an important discipline in the university training of schoolteachers. As a result, the needs of state-defined school curricula contribute decisively in shaping the content of history teaching at German universities. State funding of higher education plays a less important role in the United States than in Germany, even for public institutions. Thus, the demands of tuitionpaying students and powerful donors, together with ever louder calls for higher education to become more "useful" for professional training, are also important elements in the United States. The interplay of these factors has led to a broad decline of the study of history and other humanities in the United States. In the American history profession, the public call for research to be "relevant" for the present has further encouraged the move to contemporary history because it is perceived as "pertinent." Market considerations similarly affect academic publishing more deeply in the United States than in Germany. German historians, including the authors of dissertations and Habilitationsschriften, can easily find a publisher-provided that they can pay the subvention that is usually requested. In the United States, historiographic fashion and assumed public interest tend to limit scholars' publication opportunities.

\footnotetext{
${ }^{4}$ See the website of the ZZF: https://www.potsdam.de/node/281638.

${ }^{5}$ See the program of the 2018 Historikertag: https://www.historikertag.de/Muenster2018/sektionen/ ?term $=28$.

${ }^{6}$ The two most important prizes awarded by the VHD are the Hedwig Hintze Prize for an "outstanding dissertation" and the Carl Erdmann Prize for "outstanding Habilitationen in the whole field of history." See https://www.historikerverband.de/en/verband.html.

${ }^{7}$ The other five Hedwig Hintze Prizes were awarded to one dissertation in ancient history, two in early modern history, and two in nineteenth-century history. See https://www.historikerverband.de/nachwuchs-und-preise/preistraegerinnen/preistraegerinnen-hedwig-hintze-preis.html.

${ }^{8}$ The seven Carl Erdmann Prizes for the best Habilitation in history that were not awarded to studies on the nineteenth century were distributed nearly equally to the other epochs. See https://www.historikerverband.de/nachwuchs-und-preise/preistraegerinnen/preistraegerinnen-carl-erdmann-preis.html.

${ }^{9}$ See Benjamin Schmidt, "The Humanities Are in Crisis," The Atlantic, Aug. 23, 2018.
} 
Field-specific factors have also contributed to the changing position of the nineteenth century in historical research. In German Central European history, for example, the overshadowing dominance of the Third Reich and the Holocaust, and the shift of the "vanishing point" in research on the era from 1933 to 1941, have played an important role, as both Blackbourn and Brophy argue. ${ }^{10}$ The nineteenth century became seemingly less relevant when the Holocaust and post-1945 memory of it replaced the search for the roots of National Socialism in the century before 1933 as the focal point of research. This trend was reinforced by the general rejection of the Sonderweg thesis by the generation of historians who entered the profession beginning in the late 1980s. ${ }^{11}$ As a result, it apparently become less necessary to study the nineteenth century if one wanted to understand the "Age of Extremes."12

The nineteenth century has nevertheless been and remains of critical importance in particular thematic and historiographic subfields of Central European history, as several of the forum contributors note. This is the case, for example, in military history, Jewish history, intellectual and cultural history, as well as women's and gender history, which Roger Chickering, Simone Lässig, Suzanne Marchand, and Karen Hagemann discuss here, respectively. All four scholars call attention to exciting and innovative work on the nineteenth century, published since the 1990s, that not only questions old master narratives but also challenges the common characterization of the century as "dull." With such research in mind, Marchand argues that it is imperative for historians of the nineteenth century "to combat with all of [their] strength and imagination the lines of thought which label the nineteenth century as boring [and] irrelevant," and that measure it by today's political standards. ${ }^{13}$

Scholars of other regional fields of European history have observed a similar decline in interest in the nineteenth century. Lloyd Kramer, writing on French history in this forum, notes that "the world in which historians work has moved away from many of the concerns that shaped an earlier generation of historical scholarship and led people to the nineteenth century ... Since historians are always drawn to subjects that seem important and relevant to their own concerns, a resurgence of interest in nineteenth-century France seems unlikely, at least in North America and probably in Europe and elsewhere too." ${ }^{14}$ Historians who seek to address the most pressing issues of the present-from economic globalization and growing social inequality, to humanitarian crises and the resurgence of populism and authoritarianism in many regions of the world-increasingly focus on the twentieth century, in particular the

\footnotetext{
${ }^{10}$ Helmut Walser Smith, “The Vanishing Point of German History: An Essay on Perspective," History E Memory 17, no. 1/2 (2005): 269-95.

${ }^{11}$ See Blackbourn, "Honey"; Marchand, "Embarrassed." On the development of German history in the United States, see also Catherine Epstein, "German Historians at the Back of the Pack: Hiring Patterns in Modern European History, 1945-2010," Central European History 46, no. 3 (2013): 599-639; Andrew I. Port, "Central European History since 1989: Historiographical Trends and Post-Wende 'Turns,", Central European History 48, no. 2 (2015), 238-48, esp. 238-39; Philipp Stelzel, History after Hitler: A Transatlantic Enterprise (Philadelphia: University of Pennsylvania Press, 2018); Karen Hagemann and Donna Harsch, "Gendering Central European History: Changing Representations of Women and Gender in Comparison, 1968-2017," Central European History 51, no. 1 (2018): 114-27.

${ }^{12}$ Erich Hobsbawm, The Ages of Extremes: A History of the World, 1914-1991 (New York: Vintage Books, 1996).

${ }^{13}$ Suzanne Marchand, “Celebrating 'Boring' Ideas in the Age of Impatience: The Nineteenth Century in Intellectual and Cultural History," in this forum.

${ }^{14}$ Lloyd Kramer, "The Dying Study of 19th-century France," unpubl. mss. presented at the 48th Consortium on the Revolutionary Era, 1750-1850, Philadelphia, PA, Feb. 22-24, 2018. See also his contribution, "The Declining Study of Nineteenth-Century France," in this forum.
} 
period after 1945. They seem not to see the complicated and often ambiguous entanglement of long-term continuities and short-term changes, and thus tend to ignore the importance of eighteenth- and nineteenth-century developments for the present.

The trend toward presentism in research varies considerably, however, among the regional fields of European history. For example, in the historiography of Habsburg Central Europe, a field with flexible geographical, political, chronological, and topical boundaries that started to flourish in the last decade, the nineteenth century holds an increasingly important position, as Pieter M. Judson argues in his contribution. Interest in the century, he explains, was fostered "by the simultaneous opening of archives in the former East bloc states" and "the rise of histories that took up transnational topics and modes of analysis." 15 In Russian history, too, there is still considerable interest in the nineteenth century, as Alexander M. Martin observes in his contribution: "The Western historiography of Russia in the nineteenth century presents a mixed but mostly encouraging picture. The end of the Cold War led to quantitative shrinking, but also to an exciting reorientation that produced high-quality scholarship capable of reframing our understanding of Russian, European, and even global history." 16

Britain's nineteenth century, Alex Chase-Levenson notes in his contribution to this forum, "has not seen anything like so dramatic a level of defection in terms of hiring, research, or interest." One reason for this difference, he argues, is the rise of global and colonial history. Britain, the largest empire during the long nineteenth century, was the earliest and is still the most important subject of research in colonial history. ${ }^{17}$ Sebastian Conrad likewise emphasizes, in his contribution on colonial history, the revitalizing effect of postcolonial studies for nineteenth-century history. But, as much as this new field has helped to keep the nineteenth century on the research agenda of European history, Conrad argues that it also has contributed to a reperiodization that works to the detriment of the nineteenth century: historians of the twentieth century increasingly tend to incorporate "the 1880s and 1890s into their interpretation of the twentieth century. Formerly the very model of a short century, extending from 1914 through 1989, the twentieth century has itself expanded, at both ends." 18

Marchand offers a more critical reading of the impact of the colonial turn on the study of the nineteenth century. She argues in her contribution that the "failure to emphasize and appreciate the relevance of the nineteenth century is strongly related to our recent infatuation with postcolonial and poststructuralist thinking." 19 Both schools of thought emphasize what she calls "'the glass-half-empty' view of modernization, in which the Enlightenment simply created hypocritical institutions and disciplines that enslaved us in discourses, 'projects,' and identities; both taught us to keep our critical distance from triumphalist narratives produced by post-1945 politicians, scientists, and social activists." 20 She agrees with Chase-Levenson and Conrad that the colonial turn was and is important but, at the same time, she observes that, in academia today, "we have become so accustomed to being negative or even dismissive

\footnotetext{
${ }^{15}$ Pieter M. Judson, "The Study of the Nineteenth Century in Habsburg Central Europe," in this forum.

${ }^{16}$ Alexander M. Martin, "Russia's Nineteenth Century: Thoughts on the State of the Field," in this forum.

${ }^{17}$ Alex Chase-Levenson, "The Nineteenth Century in British History," in this forum.

${ }^{18}$ Sebastian Conrad, "Colonizing the Nineteenth Century: Implications of a Paradigm Shift," in this forum.

${ }^{19}$ Marchand, "Celebrating 'Boring' Ideas."

${ }^{20}$ Ibid.
} 
of 'the modernization project' that we tend to forget the extent to which modernization has also liberated us from evils such as legal inequality (including slavery and serfdom), religious discrimination, and subsistence agriculture." ${ }^{21}$ Such a one-sided negative perception, which does not acknowledge the parallel positive developments, is indeed problematic because it weakens our ability to defend important civil, social, and political rights that were won through arduous struggle during the long nineteenth century and that are today under attack by right-wing populist movements and governments. To be sure, the ways those rights were defined were often flawed, and rarely were they extended to all individuals equally. But too many people fought too long and too hard for those rights for historians of the twenty-first century to allow their achievement to be forgotten, or for these rights to be lost without any intellectual defense or political fight. As Andrew Zimmerman argues in his comment, there is still much to learn from nineteenth-century social movements like the anti-slavery, labor, and women's movements. He notes that those struggles seem indeed to be of growing interest to our students in light of today's fights for racial, social, and gender equality.

We thus argue with this forum that it is time to reinvigorate the study of the nineteenth century and make clear its continued relevance by taking up new questions, perspectives, and approaches. One important reason for this argument is that the major present-day challenges usually considered to be phenomena of the twentieth and twenty-first centuries actually have their roots in the nineteenth century: the challenges arising, for example, from industrialization, urbanization, large-scale internal and cross-border migration, or from new conceptions of state, nation, citizenship, and rights. Other issues that link the present to the nineteenth century are the rise of nationalism, militarism, colonialism, empire-building, and, last but not least, the dichotomic notion of a gender order, which is based on heterosexuality and the male-breadwinner family that defines the economy, politics, the military, and war as male "spheres," and home and family as female "spheres." Despite the long struggle for gender equality and all the legal, social, and cultural changes, this notion is still influential. ${ }^{22}$

If we historians want to understand the nineteenth-century roots of these developments, and if we want our students and the public to understand them as well, we need to bring, as several discussants in this forum argue, new questions and concepts to the study of this century. The decline in the interpretive power of conventional periodization, historiographical master narratives, and binary concepts, demands more complex and entangled histories of nineteenth-century Europe. This starts with the periodization of the nineteenth century. Several of the contributions highlight the trend toward shifting boundaries of the nineteenth century. Depending on the region, field, or conceptual approach, this period is differently defined. It can reach back into the eighteenth century and/or forward into the twentieth, or it might also be significantly shortened.

The innovative research discussed in several of the contributions similarly challenges traditional master narratives by approaching the century from comparative, transnational, transregional, and global perspectives, and by utilizing multidisciplinary approaches that combine the perspectives of political, social, military, cultural, and gender history. Building on that work, we need more studies that adopt a long-term perspective and that explore continuities

\footnotetext{
${ }^{21}$ Ibid.

${ }^{22}$ See Jürgen Osterhammel, The Transformation of the World: A Global History of the Nineteenth Century, trans. Patrick Camiller (Princeton, NJ: Princeton University Press, 2014).
} 
and changes from the eighteenth century far into the twentieth. Such longue durée studies will demonstrate the importance of precisely that period of the long nineteenth century that has "vanished" most from recent research, namely, the "transitional time" between 1750 and 1850 that German historian Reinhart Koselleck labeled the Sattelzeit and conceptualized as an "epochal threshold" (Epochenschwelle) between early modern and modern history. ${ }^{23}$ The Sattelzeit concept, even though it has been criticized, might nevertheless be helpful in revitalizing the study of the period between 1750 and $1850 .{ }^{24}$ Recent work on the European history of the late eighteenth and early nineteenth centuries points to the central importance of this time for several fundamental economic, political, and social developments in the long nineteenth century. It also makes clear that many people who lived then, much like many people today, saw their times as a period of dramatic change that gave rise to widespread anxiety and "feelings of dispossession." 25 A better understanding of the emotional, social, and political responses to the sense of "crisis" during this era might help surmount some of the challenges we face today.

\footnotetext{
${ }^{23}$ See Reinhart Koselleck, "Über die Theoriebedürftigkeit der Geschichtswissenschaft," in Theorie der Geschichtswissenschaft und Praxis des Geschichtsunterrichts, ed. Werner Conze (Stuttgart: Ernst Klett, 1972), 10-28, 14-15; idem, "Einleitung," Geschichtliche Grundbegriffe. Historisches Lexikon zur politisch-sozialen Sprache in Deutschland, vol. 1: A-D, ed. Otto Brunner, Werner Conze, and Reinhart Koselleck (Stuttgart: Ernst Klett, 1972), xxiv.

${ }^{24}$ See, e.g., Elisabeth Décultot and Daniel Fulda, eds., Sattelzeit: Historiographiegeschichtliche Revisionen (Berlin: Oldenbourg Verlag, 2016); Gabriel Motzkin, "On the Notion of Historical (Dis)Continuity: Reinhart Koselleck's Construction of the Sattelzeit," Contributions to the History of Concepts 13, no. 2 (2018): 145-58. Koselleck himself made clear that the term Schwellenzeit ("threshold period") would have been more precise; see Reinhart Koselleck and Christof Dipper, "Begriffsgeschichte, Sozialgeschichte, begriffene Geschichte," Neue Politische Literatur 43 (1998), 195; Jan Werner Müller, "On Conceptual History," in Rethinking Modern European Intellectual History, ed. Darrin M. McMahon and Samuel Moyn (New York: Oxford University Press, 2014).

${ }^{25}$ Peter Fritzsche, "Specters of History: On Nostalgia, Exile, and Modernity," American Historical Review 106, no. 5 (2001): 1589; see also Richard Terdiman, Present Past: Modernity and the Memory Crisis (Ithaca, NY: Cornell University Press, 1993), 66-71.
} 


\title{
Nineteenth-Century German History: Dangling in Space?
}

\author{
David Blackbourn (Vanderbilt University)
}

$\mathrm{H}$ AS there been a decline in interest in nineteenth-century Germany? Undoubtedly. In preparing a talk at the 2013 German Studies Association meeting in Denver, I did some research on this. I looked at history papers given at the German Studies Association itself, book reviews in the journal Central European History, lists of new dissertations, and the podcasts on "new books in German history" from the National History Center. What I found in each case was a fairly consistent 25-25-50 breakdown: 50 percent dealing with the period since 1945, 25 percent with the years 1914-1945, and 25 percent with the rest-everything from the Alemanni in the third century to the July Crisis of 1914. The fall-off in papers, articles, and books on the nineteenth century was especially steep. Being a historian of the nineteenth century today resembles relegation to niche status, like the foreign foods section of a big grocery store.

That is what has been happening. But why? One reason is simply that time moves on. When I was an undergraduate, Imperial Germany (on which I later wrote my dissertation) had ended fifty years earlier. Count back fifty years from today and you get to anti-Vietnam protests and the shooting of Rudi Dutschke. The thirty-year rule that governs access to government archives creates a constantly moving line. Every year, another slice of postwar history is opened up. More than that, though, the epochal events of 1989-1990 made it easier to draw a line under the "short twentieth century" and make it "available for history"- or geschichtsfähig. ${ }^{1}$ When, soon afterward, the calendar flipped over and we entered the twenty-first century, the nineteenth century was suddenly no longer the "last century," and that was psychologically important. At the same time, as I argued in my talk, the system of incentives for scholars entering the profession (funding opportunities, the way positions are defined, perceptions of what's in and what's out) favors the twentieth century.

Yet, more is going on here than altered incentives and the simple passage of time- which is another way of saying that the passage of time is never simple. There are many reasons for the move out of the nineteenth century, some particular to German history. The collapse of the German Democratic Republic (GDR) not only raised large interpretive questions, but also permitted immediate access to archival materials usually subject to the thirty-year rule. This generated a flurry of work. A second specifically German shift of interest was more fundamental: the change in how scholars approached the Third Reich, that great testing ground for historical interpretation. Once the big question was: "How did we get to 1933?" Now the question is: "How was the Holocaust possible?" In other words, 1941, not 1933, has become the "vanishing point," to use Helmut Walser Smith's term. ${ }^{2}$ The focus has shifted to the Holocaust and what came after-Auschwitz trials and Wehrmacht exhibitions, memory and commemoration. We have moved away from

\footnotetext{
${ }^{1}$ Paul Nolte, "Abschied vom 19. Jahrhundert oder Auf der Suche nach einer anderen Moderne," Geschichte and Gesellschaft, Sonderheft 22 (2006): 103-32.

${ }^{2}$ Helmut Walser Smith, The Continuities of German History: Nation, Religion, and Race across the Long Nineteenth Century (New York: Cambridge University Press, 2008), 13-38.
} 
arguing about the path to 1933, once a staple of historical debates. The continuities across the former Stunde Null (zero hour) have been emphasized, and rightly so. The continuities back to the decades before 1914 have been played down, and there is good reason for that as well. The emphasis on the conjunctural and contingent has been salutary. Big events do not always have deep, structural causes - or not only deep structural causes. No one has ever questioned the watershed quality of World War I, but increasingly it seems to be regarded as the starting point of modern times, i.e., of our times. Where Thomas Nipperdey once famously said of modern German history, "Am Anfang war Napoleon" (In the beginning was Napoleon), and Hans-Ulrich Wehler riposted "Am Anfang steht keine Revolution" (In the beginning there was no revolution), the unspoken assumption today is more often "Am Anfang war der Erste Weltkrieg" (In the beginning was World War I). ${ }^{3}$ That seems to me a half-truth.

The attenuated sense of continuity between the nineteenth and twentieth centuries is part of an intellectual development that goes beyond German history. My generation inherited a paradigm in which the nineteenth and twentieth centuries formed part of a unitary modern world shaped by the transformational impact of two great events: the Industrial and French Revolutions. But here, too, time has moved on. The classic industrial society that took shape in the nineteenth century has been disappearing for the last fifty years. And the French Revolution is finally over, as Francois Furet provocatively insisted in the late 1970s. ${ }^{4}$ We have drawn a line under the foundational events of what was once "the modern era." Or, put another way, we have abandoned a teleological master narrative in which political struggles were fought over "progress," and social struggles were engaged over industrialization, urbanization, secularization, and modernization. It was the "failure" of Germany to follow the script that produced the Sonderweg (special path) argument. We are well rid of it and of many assumptions underlying modernization theory. But we are left with a nineteenth century dangling in space.

So how might nineteenth-century history be brought back in? Let me suggest several possible thematic clusters, drawing on my long-term interest in German transnational and global history. One is the history of migration. A particular form of this was political emigration. We are accustomed to hearing that flight from the Third Reich means that German history in the mid-twentieth century needs to be written also from Prague and Istanbul, from London and Pacific Palisades. True enough. And German history after the Karlsbad decrees of 1819, and again after the revolutions of 1830 and 1848, and for Social Democrats after 1878, has to be written from Berne, Zurich, London, Paris, Hoboken, and Adelaide. German émigrés sometimes had a major political role in their host countries, while émigré experience colored German liberal, nationalist, and radical politics during much of the nineteenth century. It even created some of the same tensions we recognize from the years 1933-1945 between those who left and those who stayed (in the 1850s, for example) in a form of "inner emigration."

There is also a much longer prehistory to the turbulent mass movements of Germans and non-Germans out of and into German territory in the last hundred years. At least 4.5 million Germans left in the nineteenth century for other parts of Europe and overseas: the United

\footnotetext{
${ }^{3}$ Thomas Nipperdey, Deutsche Geschichte 1800-1866 (Munich: C. H. Beck, 1983), 11; Hans-Ulrich Wehler, Deutsche Gesellschaftsgeschichte, vol. 1, 1700-1815 (Munich: C. H. Beck, 1987), 35.

${ }^{4}$ Francois Furet, Interpreting the French Revolution, trans. Elborg Forster (New York: Cambridge University Press, 1981); originally published in France in 1978 as Penser la Révolution française.
} 
States, Latin America, Canada, Australia, and New Zealand. This turned Paris (in the 1840s) and Chicago (in the 1880s) into major "German" cities of their time. Emigration had an important place in nationalist discourse throughout the nineteenth century, while the construct of the Auslandsdeutsche played a malign role in German politics that persisted long into the twentieth century. It was also one of the drivers of German colonialism. As early as the 1830s and 1840s, there were calls for colonies - in North America, South America, perhaps Africa - that would prevent Germans being "lost" to the nation. The reversal of the outward migratory flow in the late nineteenth century and the movement into the Kaiserreich of Italian, Dutch, and especially Polish workers then created tensions and was exploited politically in ways not dissimilar to what we see today - not coincidentally, given that these movements of people around 1900 also formed a part of globalized capital and labor markets.

The same global traffic, in the era of the steamship and telegraph, saw Germans spread around the world as merchants, missionaries, scientists, foresters, mining engineers, and, of course, military advisers. Increasing numbers of Germans lived transnational lives. All of this had effects at home, even on those who never left, whether via the "Uncle in America" or the imprint on German daily life made by "colonial goods" and "people shows." Another promising way to approach nineteenth-century German history from a transnational perspective is by looking at cultural transfer. I am thinking, on the one hand, of the spread or adoption abroad of German cultural institutions and practices (e.g., the research university, academic disciplines, music), which often fed a German sense of hubris in the last years of the nineteenth century, and, on the other, of the German appropriation of a variety of foreign cultural forms - for example, in art, architecture, and sports. Tracing the history of transfers, linkages, and adaptations gets us beyond generalizations about German "cultural influence" or "antimodernism." It makes it easier to recognize cultural hybridity. In the same way, fine-filigree studies of merchant networks in the Atlantic world or the history of a particular firm, like Angelika Epple's exemplary study of the Stollwerck chocolate company (she calls it a "microhistory of globalization"), take us beyond the abstractions of import and export statistics. ${ }^{5}$ There are many ways in which commodity history and global history can be effectively pursued together to cast German nineteenth-century history in a new light. From the eighteenth century into the nineteenth, the German interior was linked to the slave trade, importing sugar and producing metal goods for exchange in Africa and exporting textiles to clothe plantation slaves. Fast forward to the period after the 1870s and a wide range of globally produced foodstuffs provided the calorific energy that made possible a growing urban-industrial workforce. Hostility to imports of American wheat and Argentinian beef, in turn, fueled peasant demands for tariff protection. Tariffs and protectionism have a whiff of 1970s social history to them (indeed, I recall writing about them in the 1970s). But if second acts are possible in American lives, then why not in German history?

Veterinary arguments were one weapon that agrarian conservatives used to keep foreign produce out of Germany in the Wilhelmine era. That was cynical and self-serving. But it reminds us of another form of global traffic in the nineteenth century: the movement of nonhuman species, whether deliberately introduced into zoos and botanical gardens, or accidentally as stowaway invasive species. Diseases like cholera that threatened humans, species like

\footnotetext{
${ }^{5}$ Angelika Epple, Das Unternehmen Stollwerck. Eine Mikrogeschichte der Globalisierung (Frankfurt/Main: Campus, 2010).
} 
the Colorado Beetle and phylloxera that attacked domestic crops, the flora that were emptied out of the ballast tanks of steamships and floated up German waterways - all were signs of the interlinking of Germany with the wider world in ways that deserve more attention from historians, not least because of the light they shed on the environmental challenges we face today.

I have sketched out a number of themes that allow us to see nineteenth-century German history in new ways that derive from a transnational or global approach-decentering or "provincializing" German history. All speak, directly or indirectly, to our present condition. I have drawn my examples from across the century. But, stepping back, it seems to me that the intellectual energy fueling such an approach comes from its two poles: the eras around 1800 and 1900 . One section of my forthcoming book on "Germany in the World" is devoted to the Sattelzeit. ${ }^{6}$ The term is Reinhart Koselleck's, of course, but non-German historians have done most to explore its potential. In recent years, they have powerfully restated the idea of an Atlantic revolution - indeed, of a "global crisis" between about 1770 and 1820 in Europe, the Americas, China, Japan, and South Asia. ${ }^{7}$ How this affected the German lands, what role Germans played as agents, cry out for renewed attention. These were also years of commercial transformation, demographic transition, and the emergence of an increasingly instrumental view of nature. This has also been called the "second age of discovery," when new regimes of knowledge were formed, as networks of communication became more tightly meshed through travel and exchange. Germans placed their imprint on this world. One thinks of the Forsters, father and son, circumnavigating the globe with Captain Cook, or of Carsten Niebuhr in Arabia, or of Alexander von Humboldt in the Americas. Or of the great Pietist networks of missionaries and couriers, trading pharmaceuticals and bibles in the New World, carrying books and botanical specimens across the Atlantic. Or, not least, of what it means that it was Germans who both laid the groundwork of modern racial thinking and came up with the concept of "world literature" within the same few decades. The Sattelzeit deserves to be emphasized and worked through by German historians as a key period in both German and global history. ${ }^{8}$

Then consider the nineteenth century from the other end. I suggested earlier that we not sever the origins and practices of National Socialism entirely from their nineteenth-century antecedents. There are important continuities across the divide of World War I. Not all point to the Third Reich, of course, but those that do add up to a formidable roster: the cult of the strong leader and the politics of mass mobilization, the growing salience of race and hygiene, the tensions of corporate capitalism, the explosive German combination of provincialism and

\footnotetext{
${ }^{6}$ Reinhart Koselleck, "Über die Theoriebedürftigkeit der Geschichtswissenschaft," in Theorie der Geschichtswissenschaft und Praxis des Geschichtsunterrichts, ed. Werner Conze (Stuttgart: Ernst Klett, 1972), 14-15; idem, The Practice of Conceptual History: Timing History, Spacing Concepts, trans. Todd Samuel Presner et al. (Stanford, CA: Stanford University Press, 2002), 154-69. See also the discussion in David Blackbourn, “"The Horologe of Time': Periodization in History,” PMLA 127, no. 2 (2012): 301-7.

${ }^{7}$ See, e.g., Christopher A. Bayly, The Birth of the Modern World, 1780-1914 (Malden: Wiley-Blackwell, 2004), 86-120; David Armitage and Sanjay Subramanyam, eds., The Age of Revolutions in Global Context, c. 1760-1840 (Basingstoke: Palgrave Macmillan, 2010).

${ }^{8}$ It is also true that some of the most conceptually interesting work on these years neglects the German dimension. It is remarkable, for example, that Germans barely exist in the twelve chapters of Simon Shaffer, Lissa Roberts, Kapil Raj, and James Delbourgo, eds., The Brokered World: Go-Betweens and Global Intelligence, 1770-1820 (Sagamore Beach, MA: Watson Publishing International, 2009).
} 
technocratic modernism, as well as the equally unstable compound of German sentimentality and hubris. All date from the period between the 1880s and 1933, which Detlev Peukert labeled "classical modernity." "They belong, that is, to the modern times already taking shape before 1914, a globalized world that already had bicycles, motor vehicles, urban mass transit systems, telephones, typewriters and automated offices, wireless telegraphy, department stores, modern advertising, cinema, organized professional sports, the tango, recorded music, $\mathrm{x}$-rays, chemotherapy, and aspirin. Some of these were made in Germany; others had become naturalized.

The problem is that the Sattelzeit draws our attention back to the late eighteenth century, whereas the advent of modern times draws our attention forward to the twentieth. What about the period in between? We seem to be left with a "short nineteenth century" that runs from ca. 1830 to 1880 , a century shorn of its beginning and end. Let us, then, make a thought experiment and ask what was distinctive about those middle years of the century, including the ways in which they speak (or appear not to speak) to us. We understand the revolutions, or think we do, because there have been revolutions in our own time, and 1848 in particular bore striking structural similarities to the events of 1989 and the Arab Spring. The geopolitical shift of the 1860s, the global nation-building (or rebuilding) of which Germany was just one instance, are also something we can grasp conceptually. But the language of gender differences and the legal disabilities of women, the fantastic number of servants, the bourgeois reverence for high culture, the anguish over loss of religious faith, the hostility to "mixed" marriages (i.e., Protestant-Catholic or ChristianJewish), the sentimentality (not squeamish denial) that attended death, the wordiness of political speeches and the frequent Latin tags, the low status of popular entertainers and the very high status of professors, especially history professors-all of these things take us aback, or ought to. And that, surely, is not the least of the reasons why we should make the case for nineteenth-century history-because it is unfamiliar, its relevance undoubted (all history is "relevant") but not immediately apparent, like the meaning of serious poetry. There is something that defies easy understanding, something uncanny even, about Suzanne Marchand's Tante Neunzehnjahrhundert, the seemingly dull and fusty Auntie Nineteenth Century, and that is a reason to study it. ${ }^{10}$ In doing so, we open ourselves to the unexpected, the seemingly inexplicable, the things (sexual mores, legal codes, jokes) that seem strange to us, the evidence of life-worlds not easily assimilable to our own experience or redescribed in our terms. They are reminders that the past truly is a foreign country, although-like all foreign countries - it teaches us about our own.

\footnotetext{
${ }^{9}$ Detlev J. K. Peukert, The Weimar Republic: The Crisis of Classical Modernity, trans. Richard Deveson (New York: Hill \& Wang, 1992).

${ }^{10}$ Suzanne Marchand, "Embarrassed by the Nineteenth Century," in Consortium on Revolutionary Europe, 1750-1850: Selected Papers, 2002, ed. Bernard Cook et al. (Tallahassee, FL: Consortium on Revolutionary Europe, 2004), 1-16.
} 


\title{
A Vanishing Nineteenth Century in Central European History?
}

\author{
James M. Brophy (University of Delaware)
}

$\mathrm{T}$ HE decline in monographs, conference papers, and college courses on nineteenthcentury Central European history is indisputable, and it joins a much broader trend in the humanities. We need not detail the curricular drift from the humanities to the sciences, engineering, and business studies: this tectonic shift is well documented. ${ }^{1}$ The migration toward vocation-oriented majors antedated the financial crisis of 2008 , but the economic panic strengthened the trend, resulting in fewer faculty hires for scholars in the humanities. And when deans and provosts now authorize hiring lines for history departments, they are less inclined to choose European history, a traditionally overrepresented section in American history departments. More frequently, open positions become opportunities to fulfill commitments toward global, cross-cultural initiatives. Historians of modern Europe are, of course, vital to these pedagogical visions, but the laudable aim for cultural diversity and geographical balance amounts to a zero-sum game that often means fewer hires in European history. ${ }^{1}$

Alongside economic downswings, new academic goals in North American universities, and public skepticism toward the value of the humanities, four intellectual impulses also undercut the primacy of Central Europe's long nineteenth century. Postmodernism's "embarrassment" of the century's celebration of industry, nationalism, empire, and progress marked a significant sea change; the cultural and linguistic turns clearly pivoted away from economic and parliamentary history to explore other, more subtle pathologies of the modern condition. ${ }^{2}$ The second critical moment was the cumulative effect of deindustrialization in the West and the dissolution of the Soviet Union. It upended the study of Western European labor movements, union politics, radical democracy, political economy, and the struggle for social-democratic justice during the nineteenth century. Why the collapse of twentieth-century Soviet Communism occludes the study of earlier democratic socialisms remains a peculiar and disturbing development of the post-Cold War era.

The Sonderweg debate and its historiographical fallout in the 1990s comprises the third major shift in intellectual focus. Dismantling the master narrative of Germany's exceptional and flawed path to modernity provided new sight lines for reimagining civil society and political culture, but such interpretive flexibility came at a price. For many lay readers and students, the drama of the nineteenth century-the deficiencies of 1848, Otto von Bismarck's pseudoconstitutionalism, the Kaiserreich's militarism-was precisely its role as the opening act to twentieth-century tragedy. Finally, the urgency to exploit newly opened archives to research the rise and fall of the German Democratic Republic (GDR) stands out as a pivotal reorientation. The predominance of GDR topics among recent

\footnotetext{
${ }^{1}$ For a recent iteration of the crisis in humanities, see Eric Hayot, "The Sky is Falling," in the Modern Language Association's Humanities Commons (https://profession.mla.hcommons.org/2018/05/21/thesky-is-falling/).

${ }^{2}$ Suzanne Marchand, "Embarrassed by the Nineteenth Century," in Consortium on Revolutionary Europe: Selected Papers, 2002, ed. Bernard Cook et al. (Tallahassee, FL: Consortium on Revolutionary Europe, 2004), 1-16.
} 
doctoral cohorts reduced the institutional presence of nineteenth-century history. All told, the impression of a shrinking field is warranted. The proportional decline of book reviews for nineteenth-century history in Historische Zeitschrift, Sehepunkt, and H-Soz-Kult suggests a similar trend in Germany. ${ }^{3}$

But the "vanishing nineteenth century" is more about quantity than quality of research. The field remains a vital laboratory of innovation and reorientation. A cursory survey of Christopher Bayly's and Jürgen Osterhammel's expansive canvases, David Blackbourn's forthcoming panoramic study of Germans in the world, Suzanne Marchand's probing intellectual history of German orientalism, Sebastian Conrad's programmatic work on colonialism and globalization, Pieter Judson's startling reinterpretation of the Habsburg Empire, Norbert Bachleitner's penetrating quantitative analysis of Habsburg censorship, James Retallack's revelatory study of antidemocratic politics in Saxony, Karen Hagemann's trenchant reassessment of national remembrance, and Christopher Clark's magisterial reevaluation of Europe's diplomatic structures on the eve of World War I, reveals no shortage of creative, groundbreaking work in our field. ${ }^{4}$ All these studies point to topics that connect the nineteenth century to the questions and research programs of current scholarship.

For the fraying modernity of a destabilized twenty-first century, the nineteenth century offers greater interpretative saliency than the bipolar global order of the second half of the twentieth. When addressing hot-button issues such as mobility and migration, globalized capitalism, franchise manipulation, and the rise of right-wing populism, the nineteenth century offers striking parallels. The economic nationalisms of the late nineteenth century, with its tariff politics, chauvinist protectionism, and global dimensions, cry out for comparison with the Trump era. ${ }^{5}$ The present volatility in global governance calls for renewed reflection on previous state systems and their mechanisms for balancing power. Whether looking at the late Holy Roman Empire, the German Confederation, or the nation-state system after 1870, the pattern of achieving continental peace through martial violence at the imperial level should frame analyses of twenty-first century instability. ${ }^{6}$ If the centennial meditations on the Great War underscored the trauma of total war for modern times, the

\footnotetext{
${ }^{3}$ In 2002, the year of its first full run as an electronic journal, Sehepunkte published 28 reviews in nineteenth-century history, as compared to 73 on twentieth-century topics. In 2017, the journal published 37 reviews on the nineteenth century, whereas the number for the twentieth century rose to 160; see http:// www.sehepunkte.de/archiv/ausgaben/. For a broader comparison of relative decline, see David G. Blackbourn, "Honey, I Shrunk German History," German Studies Association Newsletter 38, no. 2 (2013-2014): 44-53.

${ }^{4}$ Christopher Bayly, The Birth of the Modern World, 1780-1914: Global Connections and Comparisons (Oxford: Blackwell, 2004); Jürgen Osterhammel, Die Verwandlung der Welt. Eine Geschichte des 19. Jahrhunderts (Munich: C. H. Beck, 2008); David Blackbourn, Germany in the World, 1500-2000 (New York: W. W. Norton, forthcoming); Suzanne Marchand, German Orientalism in the Age of Empire: Religion, Race, and Empire (Cambridge: Cambridge University Press, 2010); Pieter Judson, The Habsburg Empire: A New History (Cambridge, MA: Belknap, 2016); Norbert Bachleitner, Die literarische Zensur in Österreich von 1751 bis 1850 (Vienna: Böhlau, 2017); James Retallack, Red Saxony: Election Battles and the Spectre of Democracy in Germany, 1860-1918 (Oxford: Oxford University Press, 2017); Karen Hagemann, Revisiting Prussia's Wars against Napoleon: History, Culture, Memory (Cambridge: Cambridge University Press, 2015); Christopher Clark, The Sleepwalkers: How Europe Went to War in 1914 (London: Allen Lane, 2013).

${ }^{5}$ Cf. Cornelius Torp, Herausforderung der Globalisierung. Wirtschaft und Politik in Deutschland 1860-1914 (Göttingen: Vandenhoeck \& Ruprecht, 2005).

${ }^{6}$ See Peter Wilson, The Holy Roman Empire: A Thousand Years of Europe's History (London: Allan Lane, 2016), which makes a persuasive case for its current relevancy. For an insightful forum on this
} 
quarter century of military conflict between 1792 and 1815, the first wave of mass war, is still not fully appreciated. ${ }^{7}$ No less important is the task of periodizing and defining the Anthropocene, which renders nineteenth-century attitudes and perceptions toward the environment, industrialization, and technology as essential starting points.

When plotting technological epochs - from the onset of the division of labor, through the ages of mechanization and digitization, to today's artificial intelligence- the long nineteenth century remains an interpretive touchstone for assessing the impact of technology on cultural attitudes and practice. ${ }^{8}$ Within this discussion, the socially constructed categories of modern time regimes need reevaluation. Oliver Zimmer's critique of homogeneous time in the railway age and Jean-Michel Johnston's nuanced analysis of telegraphy's reception offer research designs with broader application. ${ }^{9}$ Finally, the civil codes and cultural norms of the nineteenth century that erected the modern gender binary should frame and instruct twentyfirst century discussions of gender expression. ${ }^{10}$ Time has indeed moved on, but many subjects draw the nineteenth century closer.

Innovative methods in our field also invite wider application. To take the resurgence of ethnic nationalism as a focused example: three methods used for the long nineteenth century are instrumental for assessing other exclusionary claims to citizenship. (Brevity precludes discussion of others.) The first is cultural transfer, or histoire croisée, an older form of transnational analysis that scholars have primarily deployed to trace the intercultural entanglement of ideas, languages, and knowledges. Exposing such cultural impulses as composite creations undercuts claims of essentialism and illuminates the coexistence of multiple identities. ${ }^{11}$ But the

groundbreaking work, see "An Empire For Our Times? A Discussion of Peter Wilson's The Holy Roman Empire: A Thousand Years of Europe's History," Central European History 50, no. 4 (2017): 547-72.

${ }^{7}$ Cf. David Bell, The First Total War: Napoleon's War and the Birth of Warfare as We Know It (Boston: Houghton Mifflin, 2007); Roger Chickering and Stig Förster, eds., War in an Age of Revolution, 1775-1815 (Cambridge: Cambridge University Press, 2010); Alan Forrest, Karen Hagemann, and Michael Rowe, eds., War, Demobilization and Memory: The Legacy of War in the Era of Atlantic Revolutions (Basingstoke: Palgrave Macmillan, 2016); Mark Hewitson, The People's Wars: Histories of Violence in the German Lands, 1820-1888 (Oxford: Oxford University Press, 2017). Katherine Aaslestad is currently finishing After the Wars: German Central Europe after Napoleonic Conquest, 1814-1848, a much-needed study that assesses the Napoleonic Wars' impact on German civil society.

${ }^{8}$ Eberhard Illner, "Fragen der Technik bei großen Ökonomen” (unpublished ms., May 2018).

${ }^{9}$ Oliver Zimmer, "Adjusting Inner Clocks: Time and Social Rhythms in the Railway Age," Journal of Modern History (forthcoming); idem, "Die Ungeduld mit der Zeit. Britische und deutsche Bahnpassagiere im Eisenbahnzeitalter," Historische Zeitschrift 308, no. 1 (2019); Jean-Michel Johnston, "The Moods of Modernity: Telegraphy in Germany, 1830-1880" (PhD thesis, Oxford University, 2017).

${ }^{10}$ For more on this, see the contribution by Karen Hagemann in this forum.

${ }^{11}$ Matthias Middell, "Kulturtransfer und historische Komparatistik-Thesen zu ihrem Verhältnis," Comparativ 10, no. 1 (2000): 7-41; Michel Espagne and Michael Werner, "Deutsch-französische Kulturtransfer im 18. und 19. Jahrhundert," Francia 13 (1985-1986): 502-10; idem, Transferts. Relations interculturelles dans l'espace franco-allemand (XVIIIe-XIXe siècles) (Paris: Éditions Recherche sur les Civilisations, 1988); Michel Espagne and Mathias Middell, eds., Von der Elbe bis an die Seine: Kulturtransfer zwischen Sachsen und Frankreich im 18. und 19. Jahrhundert (Leipzig: Leipziger Universitätsverlag, 1993); Lothar Jordan and Bernd Kortländer, eds., Nationale Grenzen und internationaler Austausch. Studien zum Kulturund Wissenstransfer in Europa (Tübingen: Niemeyer, 1995); Hans-Jürgen Lüsebrink and Rolf Reichardt, eds., Kulturtransfer im Epochenumbruch. Frankreich-Deutschland 1770-1815 (Leipzig: Leipziger Universitätsverlag, 1997); Michael Werner and Bénédicte Zimmerman, "Beyond Comparison: Histoire croisée and the Challenge of Reflexivity," History and Theory 45, no. 1 (2006): 30-50; Wolfgang Schmale, ed., Kulturtranfer. Kulturelle Praxis im 16. Jahrhundert (Vienna: Studienverlag, 2006); Phillipe Meyer, France et Prusse. Une histoire croisée (Colmar: Bentzinger, 2009); Ellen Widder, Kanzler und Kanzeleien im 
method could be more rigorously applied to locate the "heterogeneity within the homogeneity" of not only national identities and citizenshop ideals but also the ethnic customs and practices that buttress exclusionary nationhood and its ostensible claims of indigenous authenticity. A second approach is the field of memory studies, whose categories of remembrance call attention to the erasures of collective memory. Karen Hagemann's work on the Napoleonic Wars is exemplary in showing how the memory makers of the Kaiserreich wrote women and liberal democrats out of a national narrative framed by a patriarchal gender order. ${ }^{12}$ Hagemann's study is a powerful call to recover the lost voices and political visions that do not accord with collective national memory. Helmut Walser Smith's forthcoming study on nationalism in German history will refine this discussion of remembrance, thanks to the way its pioneering use of digital humanities emplots the spatial density and conceptual metamorphosis of the nation over five centuries. ${ }^{13}$

Finally, research on national indifference challenges us to think about social experience outside the nation. First used to understand the social, political, and economic behavior in the Habsburg Empire's multiethnic regions, the concept of national indifference highlights experiences and social groups unaffected by the logic and gaze of the nation and its agitators. Pieter Judson and others thus enjoin scholars to view nationalism (and indifference to it) as "situational elements of cognition, not as fundamental identity." 14 By recovering the sociopolitical outlooks of peoples who used or ignored nationalism to suit their particular ends, the approach demands a meticulous analysis of context. Detachment from any fixed nationalist loyalty might reflect disinterest, apathy, or, conversely, a calculated response to nationalist agitation, but, regardless of motives, it challenges the hegemony of nationhood in modern times. It compliments Rogers Brubaker's proposal that we avoid looking for a "distinct identity" and a "neat boundary between inside and outside," and instead study the logic of

Spätmittelalter. Eine Historire croisée fürstlicher Administration im Südwesten des Reiches (Stuttgart: Kohlhammer, 2016). For a programmatic and terminological overview, see Wolfgang Schmale, "Kulturtransfer," Europäische Geschichte Online (Dec. 2012) (http://ieg-ego.eu/de/threads/theorien-und-methoden/kulturtransfer/wolfgang-schmale-kulturtransfer/?searchterm=Kulturtransfer\&set_language=de\#Literatur); HansJürgen Lüsebrink, Interkulturelle Kommunikation. Interaktion, Fremdwahrnehmung, Kulturtransfer, 4th ed. (Stuttgart: Metzler, 2016). For a second iteration of this intercultural analysis for macrohistorical study, see Michael Werner, Deutsch-französische Geschichte 1815-1871 (Darmstadt: Wissenschaftliche Buchgesellschaft, 2019); Mareike König, Deutsch-französische Geschichte: Rivalität, Revanche und die Zerstörung des Alten Europas 1870-1914 (Darmstadt: Wissenschaftliche Buchgesellschaft, 2018).

${ }^{12}$ Hagemann, Revisiting Prussia's Wars against Napoleon. For a longer review of this book, see Central European History 51, no. 2 (2018): 310-13.

${ }^{13}$ Helmut Walser Smith, Germany: The Nation and Its Nationalism, 1500-2000 (New York: W. W. Norton, forthcoming).

${ }^{14}$ Pieter Judson, "Nationalism and Indifference," in Habsburg Neu Denken. Vielfalt und Ambivalenz in Zentraleuropa. 30 kulturwissenschaftliche Stichworte, ed. Johannes Feichtinger and Heidemarie Uhl (Vienna: Böhlau, 2016), 153. For an extensive discussion of the term, see Tara Zahra, "Imagined NonCommunities: National Indifference as a Category of Analysis," Slavic Review 69, no. 1 (2010): 93-119. For exemplary studies of national indifference, see Jeremy King, Budweisers into Czechs and Germans: A Local History of Bohemian Politics, $1848-1948$ (Princeton, NJ: Princeton University Press, 2002); Tara Zahra, Kidnapped Souls: National Indifference and the Battle for Children in the Bohemian Lands, 1900-1948 (Ithaca, NY: Cornell University Press, 2008); Pieter Judson, Guardians of the Nation: Activists on the Language Frontiers of Imperial Austria (Cambridge, MA: Harvard University Press, 2006). For a wider application of the term, especially for its use outside the Habsburg Empire, see the forthcoming volume of essays: Maarten van Ginderachter and Jon Fox, eds., National Indifference and the History of Nationalism in Modern Europe (London: Routledge, 2018). 
cultural, political, and socioeconomic networks within transnational spaces. ${ }^{15}$ Because public discourse and much of the historical profession remain trapped within national worldviews, research on cultural transfer, national remembrance, and national indifference during the nineteenth century corrects misperceptions of nationalism's origins and influence in the modern era.

The greatest danger in giving short shrift to the nineteenth century is the loss of historical depth in key questions of modernity. In so many ways, the period 1770-1830 — what Reinhart Koselleck dubbed the Sattelzeit - forms the conceptual crucible of political modernity. ${ }^{16}$ The late Enlightenment, the Age of Revolution, and the era's philosophical and ideological doctrines set in motion the problems and possibilities of participatory politics in the modern era. The long nineteenth century as a critical mediator (and transformer) of the longue durée needs renewed recognition. For instance, historiography on the Holocaust has focused on the elements of modernity that shaped the Shoah's development and execution, from antisemitism's redefinition as a "scientific" racial science, to National Socialism's mass political mobilization, to Auschwitz as a dystopic trope of Western science, management, and genocide. Traditional antisemitisms assume an ancillary role in these narratives. But the "longest hatred" remains critical for understanding why numerous social groups acquiesced in the racial extremes of the Nazi Party. The complicitous bystanders and collaborators in the killing fields of Central and Eastern Europe in 1941-1944 were not social groups animated by racial hygiene but rather by deep-seated cultural and religious animosities. Helmut Walser Smith reasserted this point in an important collection of essays, and his study of the Prussian town Konitz and its blood libel scandal in 1900 offers a disturbing reminder that popular distrust of Jews manifested itself in ancient forms of prejudice. Why denizens of this town were cognitively predisposed to embrace the scabrous lies of an antisemitic yellow press offers broader insights for past and present. ${ }^{17}$ Death camps will always embody modernity's darkest moment, but we still have much to learn about anti-Judaic and antisemitic practices over the long nineteenth century, which allowed political antisemitism to insinuate itself as a normative component of Europe's party political landscape by the 1880s. The consequences of conservatism's tactical relationship with antisemitism speak very much to current times. ${ }^{18}$ James Retallack's exposition of how conservative politics in Saxony grew to accept and work with antisemitic parties is enormously instructive, for it displays the process by which the politics of short-term alliances, fraught with ethical compromises, became an ingrained habit over time that changed the old right. ${ }^{19}$ Comparing the West's evolving uses of nativism, chauvinism, xenophobia, and antisemitism will require a number of lenses to focus on trends and patterns of antidemocratic agitation.

\footnotetext{
${ }^{15}$ Rogers Brubaker, Ethnicity without Borders (Cambridge, MA: Harvard University Press, 2004), 50.

${ }^{16}$ Reinhart Koselleck, "Einleitung," in Geschichtliche Grundbegriffe. Historisches Lexikon zur politisch-sozialen Sprache in Deutschland, vol. 1: A-D, ed. Otto Brunner, Werner Conze, and Reinhart Koselleck (Stuttgart: Ernst Klett, 1972), xv-xix.

${ }^{17}$ Helmut Walser Smith, The Continuities of German History: Nation, Religion, and Race across the Long Nineteenth Century (Cambridge: Cambridge University Press, 2008); idem, The Butcher's Tale: Murder and Anti-Semitism in a German Town (New York: W. W. Norton, 2003).

${ }^{18}$ Liberal intolerance toward religious difference is also on display. Cf. David Blackbourn, Marpingen: Apparitions of the Virgin Mary in Nineteenth-Century Germany (New York: Knopf, 1994).

${ }^{19}$ Retallack, Red Saxony, 186-229.
} 
Understanding how these forms of social tribalism shaped nineteenth-century party politics in both the United States and Europe looms as a critical agenda.

In sum, to paraphrase Claude Lévi-Strauss, the nineteenth century is "good to think." 20 The century's thematics build a solid case that broader audiences need to listen to-and think through-our stories. To command attention, we must illuminate continuity and change with force and point, recount the century's outsized and forgotten lives in vibrant prose, and reimagine the fears and aspirations of Central Europeans with equal doses of empathy and critique. By defamiliarizing the century's well-worn narratives, historians can recapture the kaleidoscopic dynamic that highlights not only the century's hypocrises and illusions but also its achievements and advances. Recognizing its fragilities sharpens the focus of ours. Situating Central Europe in the broader global frameworks of imperial economies and cultural transfers is a welcome shift well underway, and its transnational impulses should recast the interior frameworks of Central European history. Three desiderata come to mind: an opus or a series of works that wed Habsburg and German histories into an interlocking Central European story; an interpretive approach that obviates the Sonderweg binary with a comparative perspective that explains how a wide range of democratic and antidemocratic forces coexisted within a flourishing civil society; and, finally, a body of historical knowledge to provide the current republics of Germany and Austria with a deeper understanding of their success in launching and nourishing democratic political cultures. Their constitutional doctrines and political landscapes are also legacies of the long nineteenth century. Setting these continuities in bold relief is vital for sustaining a twenty-first century belief in democracy and human rights, in Central Europe and elsewhere.

\footnotetext{
${ }^{20}$ Claude Lévi Strauss, Totemism, trans. Rodney Needham (Boston: Beacon, 1963), 89.
} 


\title{
The Study of the Nineteenth Century in Habsburg Central Europe
}

\author{
Pieter M. Judson (European University Institute, Florence)
}

$\mathrm{I}$ hope that I can add some useful comments to this forum from the perspective of a field that is often - if somewhat misleadingly — called "Habsburg history" in the United States these days. Let me start by saying that I am not fully comfortable referring to my field as a "real" field in the tradition of nationally defined fields, in part because, as a community, we practitioners remain relatively undefined geographically, politically, chronologically, and topically. Several scholars regularly orbit into and out of our bailiwick, and, in my experience, we work well as a field when we simply accept these open, if ever changing, parameters. We also constitute a relatively new field. When I wrote my dissertation at Columbia University in the 1980s, one either learned German national history, or the history of what was then called Eastern or East-Central Europe, an obvious product of Cold War political divisions. Very few scholars studied the Habsburg Monarchy, and the few universities that employed these scholars generally hired them to teach in related fields. This was my own experience as well starting in the late 1980s. In the 1990s, all of this changed radically with the simultaneous opening of the archives in the former East bloc states and with the rise of histories that took up transnational topics and modes of analysis. The study of the Habsburg Monarchy in the nineteenth century benefitted enormously, as American graduate students began to view it as a ready-made site for testing transnational analyses. Somewhat ironically, this development took place just as the US government (and subsequently many universities) stopped its Cold War support for teaching the necessary research languages for the region.

If German history in the United States blossomed in the 1970s and 1980s, Habsburg history first flowered in the late 1990s and early 2000s thanks largely to the further development of that "transnational turn." As American and British graduate students sought out potential subjects for transnational analysis, they increasingly turned to the Habsburg Monarchy, exploring transregional histories within empire or across post-1918 state borders over time ("borderland studies"), transnational and transregional claims about identification and nationhood, or imperial networks in the production of the natural sciences, the arts, or industries that transcended differences of language use, national community, or region. Not all of these studies dealt solely with the nineteenth century, but all of them were clearly rooted in new interpretations of Central European society in that century. ${ }^{1}$

\footnotetext{
${ }^{1}$ On borderland studies, see Caitlin Murdock, Changing Places: Society, Culture, and Territory in the SaxonBohemian Borderlands, 1870-1946 (Ann Arbor: University of Michigan Press, 2010); Robert Nemes, Another Hungary: The Nineteenth-Century Provinces in Eight Lives (Stanford, CA: Stanford University Press, 2016); Pieter M. Judson, Guardians of the Nation: Activists on the Language Frontiers of Imperial Austria (Cambridge, MA: Harvard University Press, 2006); Omer Bartov and Eric Weitz, eds., Shatterzone of Empires: Coexistence and Violence in the German, Russian, and Ottoman Borderlands (Bloomington: Indiana University Press, 2013). On transregional and transnational claims about nationhood and identification, see Tara Zahra, Kidnapped Souls: National Indifference and the Battle for Children in the Bohemian Lands, 1900-1948 (Ithaca, NY: Cornell University Press, 2008); Dominique Kirchner Reill, Nationalists Who Feared the Nation: Adriatic Multinationalism in Habsburg Dalmatia, Trieste, and Venice (Stanford, CA: Stanford University Press, 2012); Edin Haijdarpasic, Whose Bosnia? Nationalism and Political Imagination in the Balkans 1840-1914 (Ithaca, NY: Cornell University Press, 2015); Jakub Benes, Workers and Nationalism:
} 
In recent years, the familiar nineteenth century has indeed faded as a period of studypartly, of course, because it less and less constitutes the necessary background that other disciplines require for understanding the contemporary moment. It appears to lack the immediate usefulness and relevance it once held. At the same time, however, the more intellectual and topical reasons for a declining interest in the nineteenth century are less obvious in the case of Habsburg history than they are for German history, to make the comparison with a dominant neighboring field. The increased focus in German history in the 1990s on Holocaust and memory issues, as opposed to National Socialism and the Sonderweg-what Helmut Walser Smith has referred to as a "changing vanishing point" - tended to move the research focus away from nineteenth-century origins, but this has not meant less work on the nineteenth century, for Habsburg studies at least. ${ }^{2}$ Our field has, of course, struggled with its own persistent Sonderweg, or "exceptional path," traditions. There has been considerable overlap between the two fields in terms of presumptions about the nature and character of Habsburg economy and society (and their historical development), but we historians of Habsburg Central Europe continue to face a kind of Sonderweg-thinking based specifically on the premise that the historic existence of a complex ethnic mosaic somehow defined this region (Eastern Europe as well as the Balkans) as separate in its development from that of the rest of Europe. This circumstance determined that the region's history would be dominated by the theme of ethnic conflict among rival peoples, each of which sought to gain political expression in a nation-state of its own. Much of the Habsburg scholarship on nineteenthcentury issues over the last three decades has focused in one way or another on debunking these powerful ideas, largely by developing new ways to interpret the extreme political nationalism and murderous ethnic violence that characterized the twentieth century in these regions. ${ }^{3}$

If Habsburg historians, like their German history colleagues, have generally succeeded in debunking their own Sonderweg, the fact remains that, unlike the German case, the Sonderweg arguments they face maintain a semisacred status as the primary ideological legitimation for the existence of several contemporary, self-styled nation-states. For this reason, the traditional narrative cannot easily be abandoned or even called into question by governments, their propagandists, or the general public. This problem is particularly clear from the most superficial examination of today's official commemorations and celebrations of the hundredth

Czech and German Social Democracy in Habsburg Austria (Oxford: Oxford University Press, 2017). On imperial networks that transcended language and region, see Deborah Coen, Climate in Motion: Science, Empire, and the Problem of Scale (Chicago, IL: University of Chicago Press, 2018); Alison Frank, Oil Empire: Visions of Prosperity in Austrian Galicia (Cambridge, MA: Harvard University Press, 2005); idem, "The Children of the Desert and the Laws of the Sea: Austria, Great Britain, the Ottoman Empire, and the Mediterranean Slave Trade in the Nineteenth Century," American Historical Review 117, no. 3 (2012): 410-44; Matthew Rampley, The Vienna School of Art History: Empire and the Politics of Scholarship, 1847-1918 (University Park: Pennsylvania State University Press, 2015); Jan Surman, Universities in Imperial Austria 1848-1918. A Social History of a Multilingual Space (West Lafayette, IN: Purdue University Press, 2018).

${ }^{2}$ Helmut Walser Smith, "The Vanishing Point of German History: An Essay on Perspective," History and Memory 17, no. 1/2 (2005): 269-95.

${ }^{3}$ Rogers Brubaker, Ethnicity Without Groups (Cambridge, MA: Harvard University Press, 2004). Two important works on the twentieth century that build on earlier work about the nineteenth century are Max Bergholz, Violence as a Generative Force: Identity, Nationalism, and Memory in a Balkan Community (Ithaca, NY: Cornell University Press, 2016); Emily Greble, Sarajevo 1941-1945: Muslims, Christians, and Jews in Hitler's Europe (Ithaca, NY: Cornell University Press, 2011). 
anniversary of 1918 in most of Habsburg Central Europe. To varying extents, these commemorations reiterate and reinforce highly teleological, traditional state narratives that culminate in the triumphant production of a greater Italy, Romania, or Serbia, or in the creation of the brand new states of Poland and Czechoslovakia (today the Czech and Slovak Republics). The fact that we are currently experiencing a period of revived populist nationalism, in which several political parties in each of these states compete to outdo each other in their ethnic nationalist commitments, only exaggerates the ongoing and underlying importance of those traditional nationalist narratives. In the related field of museum work, for example, we see increased controversy surrounding public representations of national histories that question the legitimacy of the work of professional historians. ${ }^{4}$ Instead of being close to abandoning these older narratives, as one might have expected after thirty years of fresh scholarship and reflection, the recycling and reproduction of old nationalist myths that date back to World War I and before only serve to confirm their fundamental lasting appeal to the lay public. Often the guiltiest parties in this endeavor are professional historians.

I make this point to underline the daily political challenges that historians of and in this region consistently face in their everyday work lives. But I also want to emphasize the extraordinary accomplishments of American and Canadian "outsiders," who have often led the way in questioning or rethinking traditional narratives, or who have offered fresh perspectives on and new ways to approach the history of Habsburg Central Europe. ${ }^{5}$ These outsiders often built impressively on earlier critical efforts by "lone" Europeans and their students-efforts that otherwise might not have had as strong an impact on the field. ${ }^{6}$ In all these cases, the nineteenth century, especially the late nineteenth century, has to, and continues to, play a crucial role. It is, of course, the century where contemporary nationalist ideologues locate their foremothers and forefathers, so to speak. For this very reason, it remains the century to which historians have repeatedly returned to understand better the dynamics of emerging nationalism, politics in civil society, and indifference to nation. ${ }^{7}$ It is also the century where historians of such diverse fields as economics, science, ethnography, statebuilding, gender and sexuality, business and industry, migration, and the arts locate key developments that undermine traditional narratives of alleged backwardness or ethnic conflict. This point suggests a rosier outlook for future interest in the nineteenth century, too, especially as the novelty of those archives that have recently revealed to us more of the Communist past begins to wear off. Graduate students and young scholars may well explore histories of capitalism, empire, the environment, and, of course, migration - all

\footnotetext{
${ }^{4}$ See, e.g., recent controversies over the Gdansk Museum of the History of the Second World War (https:// www.nytimes.com/2016/11/10/arts/design/museum-of-the-second-world-war-in-poland-debate.html).

${ }^{5}$ John Boyer, Political Radicalism in Late Imperial Vienna: The Origins of the Christian Social Movement (Chicago, IL: University of Chicago Press, 1980); Gary B. Cohen, The Politics of Ethnic Survival: Germans in Prague, 1861-1914 (Princeton, NJ: Princeton University Press, 1980); John-Paul Himka, Galician Villagers and the Ukrainian National Movement in the Nineteenth Century (New York: St. Martin's Press, 1988); Jeremy King, Budweisers into Czechs and Germans: A Local History of Bohemian Politics, 1848-1948 (Princeton, NJ: Princeton University Press, 2002); Maureen Healy, Vienna and the Fall of the Habsburg Empire: Total War and Everyday Life in World War I (Cambridge: Cambridge University Press, 2004); Zahra, Kidnapped Souls.

${ }^{6}$ See, e.g., Gerald Stourzh, Die Gleichberechtigung der Nationalitäten in der Verfassung und Verwaltung Österreichs 1848-1918 (Vienna: Verlag der Österreichischen Akademie der Wissenschaften, 1985).

${ }^{7}$ Tara Zahra, "Imagined Noncommunities: National Indifference as a Category of Analysis," Slavic Review 69, no. 1 (2010): 93-119; King, Budweisers; Judson, Guardians of the Nation.
} 
topics of highly contemporary interest - by reengaging with the nineteenth century. In that sense, history may not simply be moving forward but rather backward as well.

If there is a crisis or abandonment of the nineteenth century in our field, it has more to do with a lack of interest in, and just plain ignorance of, the period before 1848 . The first half of the nineteenth century is ripe for archival investigation. It is a period about which we know shockingly little, despite the innovative studies of the few scholars who have recently examined or are currently exploring this period. ${ }^{8}$ Most of us recognize that the traditional concepts of Biedermeier or Vormärz (and everything they traditionally connote) are outworn, but we have not yet replaced them with concepts, analyses, and narratives that would better reflect the extraordinary economic, cultural, civic, and even political dynamism that exploded during the decades between the Napoleonic Wars and the revolutions of $1848 / 1849$.

In Habsburg history, the nineteenth century may remain a topic of exploration for today's researchers, but our field suffers as much from geographic challenges as it does from chronological ones. Most of us would acknowledge that we have excellent detailed work on Vienna, Lower Austria, the Bohemian lands, Galicia, and Trieste. But we have far too little work in more broadly accessible languages (e.g., English or German) on the critical regions of Croatia, Hungary, and Transylvania. We know very little about local social life there, and we know very little about how local administrative institutions worked in those regions. This is hardly a question of merely filling some research gaps. Our very understandings of empire, of imperial society, of state-building, but also of civic and cultural life, might change considerably if we had more research situated in examples from these regions. In terms of larger studies of empire, imperial institutions, and popular relations to empire, our work is far too skewed toward Cisleithania. This is largely because of language issues. But it is also because we have tended too often to exaggerate the fascinating distinctiveness of Cisleithania's multilingual institutions, while relegating Hungary to simple "nation-state" status — a status that we are now beginning to see is neither helpful nor particularly accurate. I have recently suggested at a number of conferences that we also treat Hungary as an empire, though as a different kind of empire from its Cisleithanian counterpart, and that we recognize more fully that loud assertions about Hungary's nation-state status, or about its notorious late nineteenthcentury Hungarianization policies, are claims that do not fully reflect reality on the ground. ${ }^{9}$ Historians outside of Croatia, Hungary, Romania, and Serbia have a lot to learn about how the Hungarian state functioned at the regional and local levels, just as we have a lot to learn about how local people engaged with this and understood this state.

For the field of Habsburg Central Europe, several worrying questions regarding the funding of projects and especially the filling of university positions in Austria and the other successor states should concern North American scholars. As elsewhere in the world, the funding situation for historical projects in Central Europe is clearly worsening. Furthermore, some Austrian universities, in a misguided attempt to expand their

\footnotetext{
${ }^{8}$ Brian E. Vick, The Congress of Vienna: Power and Politics after Napoleon (Cambridge, MA: Harvard University Press, 2014); Larry Wolff, The Idea of Galicia: History and Fantasy in Habsburg Political Culture (Stanford, CA: Stanford University Press, 2010); Reill, Nationalists.

${ }^{9}$ Pieter M. Judson, "Region-State-Empire. Hungary in Comparative Context," presented at "An Empire within the Empire? Habsburg Hungary in the 19th Century and after the Dissolution," Comenius University, Bratislava, March 26, 2018.
} 
transnational and global offerings, now regularly seek to replace historians of the region with historians doing work in other fields and geographic regions. ${ }^{10}$ This effort to deprovincialize Austria is in itself highly laudable, but it creates a serious problem when it comes at the expense of positions that were devoted to the study of the multiregional Habsburg pastand that, sadly, has been the case in recent years. If professors at Austrian universities do not promote the serious study of an interregional Habsburg history, then who will do so? History departments in the other successor states suffer from a different problem, which they share with other self-styled nation states: a concentration on the retrospective legitimation of the nation. Their departments tend to focus on national stories and to avoid the study of imperial networks, connections, and common institutions that characterized the broader history of the region in the nineteenth century. Certainly, some of these departments in the Czech and Slovak Republics, in Croatia, in Hungary, and in Slovenia have produced outstanding historians of the larger region or empire- but too often as the product of a coincidence of interests rather than of intention. The solution is to promote a greater understanding of the ways that regional (or even national) histories are embedded within larger imperial, European, or global histories. Regional history does not have to be overly provincial in character if it is practiced with an eye to different levels and scales of analysis. But I have too often heard the assertion in Austria that hiring historians of Austria (not to mention its imperial past) will only narrow the perspectives of scholars.

In considering possible ways to revive or sustain interest in the nineteenth century, I wonder whether the problem of diminished interest might not afford us opportunities to abandon or to rethink traditional and possibly outmoded ways of thinking about periodization and chronology. Might it not be a positive development that, instead of seeing the nineteenth century simply as the century of change that produced the modern twentiethcentury world, we see it as much in terms of its links to early modern worlds, and that we therefore configure the chronology differently? Scholars of the eighteenth century already assert a "long eighteenth century," and it might be beneficial to start thinking in terms of a short nineteenth century. Indeed, we might want to think of a nineteenth century that profits from the ways early modernists have formulated categories such as globalization and state-building. In sum, diminished levels of interest in Europe's nineteenth century may offer us significant opportunities to change how we define our subject and to rethink the very significance of our fields and of how they relate to others.

Finally, as mentioned earlier, today's graduate students are already reexamining in new and critical ways many of the classic themes we associate with the nineteenth century. Topics long associated with political, social, economic, and cultural history such as welfare, labor, state-building, gender, family life, education, civic life, and many others remain at the center of our endeavors, but they are framed much differently, of course. My department of twelve professors at the European University Institute in Florence only trains doctoral students in early modern and modern European history. At the same time, we are committed to a global understanding of Europe from the fifteenth century to the present, which means that our students often explore European topics in places as diverse

\footnotetext{
${ }^{10}$ See, e.g., "Deutsche schreiben unsere Geschichte," Salzburger Nachrichten Feb. 23, 2017, and the comment by Heidemarie Uhl, "Was in der Debatte über einen Grazer Lehrstuhl schiefläuft," Die Presse, Feb. 16, 2017 (http://diepresse.com/home/meinung/gastkommentar/5170915/Was-in-der-Debatteueber-einen-Grazer-Lehrstuhl-schieflaeuft).
} 
as far-flung as Latin America, East Asia, and East Africa. Several of us advise dissertations focused on the nineteenth century or the period around 1900. Our students who write on the nineteenth century seek to reframe our understanding of issues ranging from citizenship and personal identification under the Napoleonic occupations outside of France, to transnational studies of revolutionary 1848. Still others are researching European borderlands, female entrepreneurship in the Habsburg Vormärz, or the secret police under the Ottomans. Together, they appear to be uncovering a remarkable range of unknown histories that should change our understandings of the nineteenth century throughout Europe. ${ }^{11}$

${ }^{11}$ One recent example is Waltraud Schütz, "Educational Entrepreneurs and the Politics of Schooling in Nineteenth-Century Habsburg Society” (PhD diss., European University Institute, Florence, Italy, 2018). 


\title{
Russia's Nineteenth Century: Thoughts on the State of the Field
}

\author{
Alexander M. Martin (University of Notre Dame)
}

$\mathrm{T}$ HE Western historiography of Russia in the nineteenth century presents a mixed but mostly encouraging picture. The end of the Cold War led to quantitative shrinking but also to an exciting reorientation that produced high-quality scholarship capable of reframing our understanding of Russian, European, and even global history. After a brief discussion of periodization, I will offer a quantitative survey of the challenges that the American and West European scholarship has faced, and then summarize some major historiographic trends that show its continued vitality.

The nineteenth century in Russia is not a unified era. It has no clear starting point: historians often use the imperial successions of 1796, 1801, or 1825 to mark its beginning, but none of these really marks a historic break. The entire period from 1762 (the accession of Catherine II) to the mid-nineteenth century is sometimes treated as one era, shaped by enlightened absolutism and an ancien régime similar to eighteenth-century France or Prussia. A watershed was reached in 1861, when the Great Reforms were launched with the abolition of serfdom. Much like the Prussian reforms of the Napoleonic era, the Great Reforms aimed to modernize the socioeconomic system while preserving the old political order. This ushered in the turbulent late imperial period, which came to a close with either the outbreak of World War I, or the fall of the monarchy, or the October Revolution. Russia's "long" nineteenth century thus comprises two periods, the historiographies of which have followed different trajectories. The pre-Reform era has long played second fiddle, and its recent quantitative shrinking has been gradual. By contrast, the late imperial field has experienced acute boom-and-bust phases.

Let me begin with a look at the field's evolution on a purely quantitative level. One way to do this is to count dissertations and books. For dissertations, I went to the ProQuest online database and did a search for doctoral dissertations that were defended since 1975, and that were on the subject of Russian history or had the words Russia, Russian, or Soviet in the title. ${ }^{1}$ I searched for dissertations in English, French, German, and Italian, the major languages of scholarship outside the Soviet Bloc; the overwhelming majority were in English, reflecting the dominance of American and British scholarship in this field. I then reviewed each item to decide which ones to include. I had to make many judgment calls, and no doubt I missed some titles. My numbers are only approximations; what matters are the trend lines. ${ }^{2}$

Our field's central question, until recently, was how imperial Russia became the Soviet Union. Historians until the early 1980s mostly approached this problem from the prerevolutionary side. The decade 1975-1984 produced 47 dissertations on the pre-Reform era

I thank Michael David-Fox and Peter Holquist for their helpful comments on an earlier draft of this article.

${ }^{1}$ https://www.proquest.com/products-services/pqdtglobal.html.

${ }^{2}$ No comprehensive diachronic listing of dissertations in this field seems to exist; see Patricia K. Thurston, "Doctoral Dissertations on Russia, the Soviet Union, Central Asia, and Eastern Europe Accepted by Universities in the United States and Canada, 2016," Slavic Review 76, no. 4 (2017): 1150. 
(the century before 1861), 106 on the late imperial period, and 55 on the early Soviet period (defined here as 1917-1941). ${ }^{3}$ Studies of the decades after 1941 by historians - as opposed to social scientists - were rare. Why this emphasis on the imperial era? The published sources were good and readily accessible, and the Soviet archives were relatively open for research on these topics. The context of Cold War international politics created an interest in what caused revolutions to happen. Finally, leading mentors of graduate students (such as Michael Karpovich, Marc Raeff, Nicholas Riasanovsky, and Leopold Haimson) came from émigré families, were steeped in prerevolutionary culture, and wanted to understand the failure either of the imperial regime or of alternative varieties of socialism-problems that drew their attention to the period before 1917.

From the late 1980s, the field shifted in a modern direction. Improved archival access in the Gorbachev era was a major factor. So, too, was the excitement of Mikhail Gorbachev's reforms, the new possibilities for dialogue and collaboration with scholars in the USSR, and the desire to open up new research fields. Perestroika and the disintegration of the Soviet Union placed the spotlight on 1917-1941 as the juncture when Soviet socialism had settled into its fateful path. Had there been a proto-Gorbachevian alternative to Stalin? What was the cause of the Great Terror? Thanks to perestroika and to what some have called the "archival gold rush" that it made possible, questions like these moved to the forefront of the debate. ${ }^{4}$ The 1990 s were boom years. We had our cake and could eat it, too: Russia retained its Cold War stature as a country of exceptional importance, but working conditions there-access to archives, contact with scholars-became "normal." For 1991-2000, I count 294 dissertations: 42 in pre-Reform, 118 in late imperial, and 134 in early Soviet history. This was 86 more than in 1975-1984, with nearly the entire increase in the early Soviet period.

The next decade, 2001-2010, saw a drastic shift. The number of dissertations on the preReform era actually grew, to 53, but late imperial (74) and early Soviet (86) went into steep decline. The field was moving into the late Soviet period, roughly 1941-1991. Once more, archival access and the desire to explore new research fields played a role, but there was also a larger change afoot: as in European history as a whole, the Cold War era became "history." For my cohort of Russianists-I studied in Leningrad as an undergraduate in 1984, and did my dissertation research there in 1990-1991 — the Soviet Union was still a place; for all who came after, it was a time. The question that interested more and more scholars was: why had that time ended? Social scientists had long worked on the late Soviet era; now the historians joined in. Just for the years 2006-2010, I count 52 dissertations on the late Soviet period. In the first half of the present decade, these trends have held steady: for 2011-2015, I found 17 on pre-Reform, 25 on late imperial, 40 on early Soviet, and 66 on late Soviet history.

Books in Western languages have followed the same trajectory, if the reviews published in Slavic Review are any guide. Pre-Reform and late imperial together accounted for two-thirds of the books reviewed in 1977, more than 40 percent in 1987 and 1997, and around onethird in 2007 and 2017. As between the two nineteenth-century categories, the preReform era's share was much larger in 1977; the two were equal in 1987; late imperial was much larger in 1997; and they have been at parity again in 2007 and 2017.

\footnotetext{
${ }^{3}$ Dissertations that straddle two periods are assigned in equal parts to both periods.

${ }^{4}$ Mark von Hagen, "The Archival Gold Rush and Historical Agendas in the Post-Soviet Era," Slavic Review 52, no. 1 (1993): 96-100.
} 
What, aside from changing scholarly fashions and the sheer passage of time, accounts for these developments? First, Russian studies, in general, has been in retreat since the heady days of Gorbachev and Boris Yeltsin. A recent survey asked Russianists in different disciplines whether graduate student interest in Russia had declined since the 1990s. Among historians, 62 percent agreed, as did 60 percent of scholars working in Slavic literature; in the social sciences, which have deemphasized area studies in favor of more theoretical and comparative approaches, the figure was 81 percent. The result has been a weakening of the multidisciplinary academic ecosystem that fostered an interest in Russia on the part of earlier generations of students. ${ }^{5}$

A second factor is the break-up of the Soviet Union. Previously, scholars of the minority nationalities had worked within a shared Russian or Soviet historiographical framework. The independence of the former Soviet republics has now made it possible, for example, to situate Ukraine in an Eastern European and Uzbekistan in a Central Asian context. A third factor is that we no longer have a strong master narrative to organize our field. It used to be that we all worked, directly or indirectly, on one big question: what were the causes and consequences of the fall of the Romanovs and the Bolshevik Revolution? This question kept bringing us back to the nineteenth century. Moreover, the nineteenth century was everywhere in the Soviet Union. Every leader repudiated his predecessors, but all laid claim to the legacy of the Russian revolutionaries. The regime's foreign or émigré critics, be they liberals, monarchists, or moderate socialists, were haunted by the phantom of 1917. Inside the Soviet Union, independent thinkers turned to the humanistic cultural heritage of tsarist Russia for respite from the grayness of the present, and the regime compensated for the inadequacies of its culture by celebrating the traditions of nineteenth-century literature, music, and ballet. ${ }^{6}$ To a Westerner, the Soviet Union itself could seem stuck in a time warp: on the crumbling streets of old Leningrad, where one rarely saw a car or neon sign, the nineteenth century sometimes felt closer than the twentieth.

The nineteenth century loses this centrality if one shifts one's vantage point from 1917 to 1991. Viewed from this angle, the great questions are the legacy of Stalinism, the impact of World War II, the competition between Soviet and Western modernity, and the tensions between the Russian-dominated Soviet project and the claims of the national minorities. Pre-Reform historians were less affected by this shift in perspectives because their main interest is how the nineteenth century grew out of the eighteenth, but scholars who study the late nineteenth century as the origin of the present found the intellectual ground shifting beneath their feet.

Does all this mean that the nineteenth-century field is in decline? Clearly not, if one considers who wins book prizes. Since 1990, three winners of the American Historical Association's Herbert Baxter Adams and George L. Mosse prizes for European history were books on Russia in the long nineteenth century, as opposed to just one-or two,

\footnotetext{
${ }^{5}$ Theodore P. Gerber, "The State of Russian Studies in the United States: An Assessment by the Association for Slavic, East European, and Eurasian Studies (ASEEES), July 2015" (http://www.aseees. org/sites/default/files/downloads/FINAL-ASEEES-assessment-report.pdf, p. 39).

${ }^{6}$ See, e.g., Maxim Waldstein, "Russifying Estonia? Iurii Lotman and the Politics of Language and Culture in Soviet Estonia," Kritika: Explorations in Russian and Eurasian History 8, no. 3 (2007): 561-96.
} 
depending on how one counts — on the late Soviet period. ${ }^{7}$ Since 2000, studies on the long nineteenth century have beaten those on the late Soviet period by twelve prizes to nine for the three history awards of the Association for Slavic, East European, and Eurasian Studies. ${ }^{8}$ The only works on Russia ever to win book prizes from the Urban History Association and the World History Association (both of them in the last five years) were likewise on the prerevolutionary era. ${ }^{9}$ This is clearly not a stagnating field.

The field has arguably not contracted at all, but rather expanded, thanks to the vigorous exchange that has become routine between scholars in the West and in the former USSR. The change this represents is hard to overstate. The bad press Russia receives these days in the West might lead one to imagine that a chasm divides them, but to someone who remembers the old days, the extent of Russia's convergence with the West remains a source of amazement. The effect of this convergence has been transformative. Before 1991, Western scholars could freely develop ideas, but they had trouble obtaining sources. Soviet scholars had the opposite problem, and a combination of political and logistical obstacles hampered collaboration across the Iron Curtain. All of this is largely gone. Eased visa restrictions and the mass digitization of printed materials and archival guides have vastly improved Westerners' access to sources, while our Russian colleagues are free to experiment with new ideas and methodologies. Scholarly contact, too, has expanded greatly. It used to be that a letter to the Soviet Union took weeks to arrive; today, we shoot emails back and forth. Westerners participate in Russian conferences and see their books appear in translation, while scholars from the former Soviet Union are ubiquitous at our conferences, in our journals, and at our universities.

This integration has generated exciting intellectual impulses, of which there have been at least three. One is a thematic broadening of our study of Russia itself. The revival of nationalism and religion there has led to a new interest in the history of national identities and religion, and the traditional Moscow- or St. Petersburg-centric perspective of many historians has been enriched by new work on individual regions and provinces. Second, Russia's place in the history of Europe has changed. Present-day Russia's convergence with the West has encouraged a revisionist history that stresses similarities, not differences, with Europe. In the 1980s, David Blackbourn and Geoff Eley challenged the thesis of the German Sonderweg. ${ }^{10}$ We see something similar in Russian history, and treating Russia as fully a part of Europe has implications for the whole discipline. For example, as Marc Raeff already noted in 1975, does not the liberal nation-state start to look like a Northwest European exception, not a general norm? ${ }^{11}$ The third big change is the so-

\footnotetext{
${ }^{7}$ See the lists of past winners: https://www.historians.org/awards-and-grants/past-recipients/herbertbaxter-adams-prize-recipients; https://www.historians.org/awards-and-grants/past-recipients/george-1-m osse-prize-recipients.

${ }^{8}$ See the lists of past winners: http://aseees.org/programs/aseees-prizes/wayne-s-vucinich-book-prize/ past-winners; http://aseees.org/programs/aseees-prizes/reginald-zelnik-book-prize-history/past-winnersreginald-zelnik-book-prize; http://aseees.org/programs/aseees-prizes/w-bruce-lincoln-book-prize/pastwinners-w-bruce-lincoln-book-prize.

${ }^{9}$ http://www.urbanhistory.org/Past-Awards; https://www.thewha.org/awards/bentley-book-prize.

${ }^{10}$ David Blackbourn and Geoff Eley, The Peculiarities of German History: Bourgeois Society and Politics in Nineteenth-Century Germany (Oxford: Oxford University Press, 1984).

${ }^{11}$ Marc Raeff, "The Well-Ordered Police State and the Development of Modernity in Seventeenth- and Eighteenth-Century Europe: An Attempt at a Comparative Approach," American Historical Review 80, no. 5 (1975): 1242 .
} 
called imperial turn. Historians increasingly study tsarist Russia as a transcontinental, multinational empire. It is indicative of the quality and ambition of this scholarship that two recent book prizes have gone to monographs connecting Russia with the Qing, Safavid, Ottoman, and Habsburg empires. ${ }^{12}$ Moving past the old dichotomy of Russia versus the West, Russia is increasingly integrated into a global history of empires. Historians in all fields are looking for ways to transcend the nation-state and globalize their subject matter; nineteenth-century Russian history is at the forefront of this movement. ${ }^{13}$

Nineteenth-century Russia's vitality as an academic field is an excellent reason to study and teach it, but there is another reason as well-one that applies more generally to the history of Europe as a whole. The old justifications for studying the nineteenth century may seem a bit shopworn, but our present historical moment is creating new ones. As we try to make sense of today's crisis of liberal modernity, the century that suffered its birth pangs provides food for thought. What to make of the fraying of the post-1945 international order? Maybe the breakdown of the Three Emperors' League can help us understand. Why all the unease today about globalization? Read the Slavophiles. Why the terrorists, school shooters, and opiate epidemics, and why the rage of so many who feel left behind by a changing world? Dust off your Dostoevsky and your Gorky. The nineteenth century may be passé as the origin story of a triumphant modernity, but in our age of anxiety, it feels more present than ever.

\footnotetext{
${ }^{12}$ The World History Association's Bentley Prize was awarded to Alfred J. Rieber, The Struggle for the Eurasian Borderlands: From the Rise of Early Modern Empires to the End of the First World War (Cambridge: Cambridge University Press, 2014). A co-winner of the AHA's George Louis Beer Prize was Michael Reynolds, Shattering Empires: The Clash and Collapse of the Ottoman and Russian Empires (Cambridge: Cambridge University Press, 2011).

${ }^{13}$ For an extensive discussion of the literature on the imperial turn, see Theodore R. Weeks, "Nationality, Empire, and Politics in the Russian Empire and USSR: An Overview of Recent Publications" (https:// www.hsozkult.de/literaturereview/id/forschungsberichte-1134).
} 


\title{
The Declining Study of Nineteenth-Century France
}

\author{
Lloyd S. Kramer (University of North Carolina at Chapel Hill)
}

$\mathrm{T}$ HE growing concern that nineteenth-century European history has lost its earlier academic prominence may reflect the parochial anxieties of scholars who worry about the influence of their own professional field. Although there is clear evidence of a relative decline in nineteenth-century studies, most historians in all subdisciplines would probably agree that it is impossible to understand contemporary global systems or conflicts without some knowledge of nineteenth-century Europe and its far-flung imperial expansion. A declining interest in nineteenth-century Europe may therefore suggest a broader decline in the scholarship on the pre- 1900 origins of modern global history. More generally, the receding currents of nineteenth-century studies could be part of a broader academic flow away from the humanities - for which the nineteenth century has long provided a wide range of cultural and social materials.

The declining interest in nineteenth-century history seems, however, to be more than a specific aspect of the wider skepticism about traditional humanistic work. Why, then, would historians now have less interest in such an important transitional era? If the study of nineteenth-century history has fallen into permanent decline, how can historians argue for the continuing significance of a historical period that will become more remote to every future generation? My exploration of these questions focuses on the study of nineteenthcentury France, but I view many themes of French history as relevant for the historical analysis of almost all modern societies.

When I entered graduate school in the 1970s, the conflicts and ideologies of nineteenthcentury Europe seemed much closer to the political and intellectual debates of our own historical moment. Most historians had actually known people who were alive before 1900 . These kinds of personal connections have now disappeared, and the growing chronological separation from nineteenth-century people is one reason for the falling interest in their history.

Historians develop research interests that evolve out of their personal experiences, but the evolving trends of historical scholarship also reflect wider social and cultural changes. Important books and articles on nineteenth-century French history continue to appear every year, yet the detailed bibliographical lists of recent publications in the journal French Historical Studies (FHS) show that historians are publishing more works on the post-1900 era. These publications also focus increasingly on "colonialism and overseas departments," which is the fastest growing category of recent scholarship in French history (Tables 1 and 2). ${ }^{1}$ By compiling a simple count of books and articles from FHS bibliographies of new publications in 1999-2000, 2006-2007, and 2016-2017, I found (unsurprisingly) that the

\footnotetext{
${ }^{1}$ Table 1 summarizes the number of publications in each chronological field of modern French history at three recent intervals: 1999-2000, 2006-2007, and 2016-2017. These numbers were drawn from bibliographies that are regularly published in French Historical Studies (FHS), and they provide somewhat random bibliographical "snapshots" from six twenty-first century issues of the journal: Fall 2000/Winter 2001 (vols. 23, no. 4, and 24, no. 1); Fall 2007/Winter 2008 (vols. 30, no. 4, and 31, no. 1); and Oct. 2017/ Feb. 2018 (vols. 40, no. 4, and 41, no. 1).
} 
Tables 1 and 2: Publications on French Historical Subjects as listed in the journal French Historical Studies (FHS) (Fall 2000-Winter 2001; Fall 2007-Winter 2008; Oct. 2017-Feb. 2018)

Books published on French History at three intervals since 2000

Period

All Languages English

Era of the French Revolution and Napoleon (1789-1815)

1999-2000

2006-2007

2016-2017

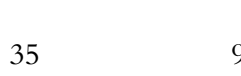

Era of 1815-1870

1999-2000

2006-2007

2016-2017

$37 \quad 15$

Era of the Third Republic (1871-1940)

1999-2000

2006-2007

2016-2017

$92 \quad 9$

1940 to the Present

1999-2000

2006-2007

2016-2017

$13 \quad 1$

$18 \quad 3$

243

Colonialism and Overseas Departments (mostly on 1900 to the present)

1999-2000

2006-2007

2016-2017

$\begin{array}{ll}33 & 17 \\ 16 & 4 \\ 111 & 14\end{array}$

$49 \quad 18$

$46 \quad 10$

$107 \quad 15$

Scholarly articles published on French History at three intervals since 2000*

Period

All Languages

English

Era of the French Revolution and Napoleon (1789-1815)

1999-2000

2006-2007

2016-2017

0

$12-4$

$76 \quad 11$

Era of 1815-1870

1999-2000

2006-2007

2016-2017

Era of the Third Republic (1871-1940)

1999-2000

2006-2007

2016-2017

1940 to the Present

1999-2000

2006-2007

36

7

47

\section{6}

18

54

78

82

94

71

80

81
15

,

3

17

\footnotetext{
*No separate category on colonialism has been created for FHS bibliographies of articles.
}

twentieth-century has become the most commonly studied era in modern French history. This emphasis is all the more striking when studies of colonial and postcolonial history are counted, though some of this work extends into the present century or examines earlier periods of colonial expansion. FHS did not even list colonialism and overseas departments as a component of its bibliographies in 2000, but 76 books (published in 2016-2017) appeared in this new category when the journal listed its regular bibliography in October 2017. 
To be sure, the FHS bibliographies are simply "snapshots" of recent trends, but such lists offer a good overview of general patterns. In the summaries for October 2017, for example, there were 24 new books on the era between 1815 and 1870, compared to 107 books on the era "1940 to the Present" - plus the additional 76 on colonialism (mainly on the period since 1900). It would be interesting to track long-term patterns in French historical scholarship by developing much more carefully researched lists of publications over the last fifty years. It seems likely, though, that such lists would show that more historians between, say, 1960 and 1995 were examining nineteenth-century France "within the hexagon," and far fewer were working on colonialism, overseas territories, or postcolonialism.

There are interesting perspectives on the earlier importance of nineteenth-century French history in the autobiographical reflections of several historians who began their careers in the later twentieth century. Laura Lee Downs and Stéphane Gerson published in 2007 an excellent collection of essays titled Why France? American Historians Reflect on an Enduring Fascination, to which members of that generation contributed. ${ }^{2}$ Most of the contributors note their fascination with France's history of radical protests, revolutionary upheavals, worker organizations, and cultural creativity. Many discuss how they learned about France during or after the French student protests of May 1968. They also describe the pleasures of French wines and food, as well as the nuances of the French language. For most historians of this post-1968 generation, however, France's political, social, and cultural complexities became a decisive influence on their decisions to pursue advanced historical research.

Each historian tells a different story, but many of his or her interests converged on the nineteenth century. Herman Lebovics, for example, sought to understand how late nineteenth-century French economic elites looked for "solutions to the problem of containing revolution." Thomas Kselman, who wanted to understand the connections between religious beliefs and modern culture, found that "Catholic devotions in nineteenth-century France" offered an especially helpful "historical case for thinking about religion and religious change in the modern world." As she staked out her distinctive historical approach to modern psychology, Jan Goldstein "became intent on unearthing the bureaucratic connections of the nascent psychiatric profession," both before and after "passage of the asylum law of 1838." This research helped her understand the systems of a modern "centralized bureaucracy." Meanwhile, Edward Berenson was becoming "interested in the role of popular religion in politicizing workers before and during the revolution of $1848 . " 3$

Like others in the decades after 1965, these historians seemed to turn toward nineteenthcentury France because of the conflicts and social-cultural changes that reshaped the nation during that transitional era: 1) political revolutions, 2) the social-economic changes of the industrial revolution, 3) the cultural imagination of writers and artists, and 4) the critical theories of social reformers. The long nineteenth century provided rich sources for research on all these themes, but new challenges began to emerge as it became apparent that each theme

\footnotetext{
${ }^{2}$ Laura Lee Downs and Stéphane Gerson, eds., Why France? American Historians Reflect on an Enduring Fascination (Ithaca, NY: Cornell University Press, 2007). In addition to the editors' introduction and an afterword by Roger Chartier, there are essays by sixteen American historians of France who mostly completed their graduate studies between the 1960s and 1990s.

${ }^{3}$ These statements are from Herman Lebovics, "Tough Love for France"; Thomas Kselman, "Catholic Connections, Jewish Relations, French Religion"; Jan Goldstein, "Europe without Personal Angst"; Edward Berenson, "France, A Political Romance," in Downs and Gerson, Why France?, 52, 116, $131,145$.
} 
could also be studied in other places and cultures that were more directly relevant to presentday concerns and identities.

France's revolutionary upheavals have long fascinated historians. How and why did the French overthrow their monarchical government in the 1790s? How did this revolution influence later revolutionary movements in Europe and in other parts of the world? These questions have traditionally led historians deep into nineteenth-century political debates because the French were obsessed with these issues after 1815. Conservatives, liberals, socialists, and nationalists all wanted to explain the causes of modern revolutions and the consequences of revolutionary changes. The Revolution of 1848 and the Commune of 1871 also became major subjects for research and theoretical analysis. But the study of revolutions and their legacies now attracts less interest and pedagogical attention, perhaps because almost nobody believes that such revolutions are possible in modern societies. They are viewed as interesting examples of past political changes, rather than as precedents for political action in modern states that possess overwhelming police and military forces.

Nineteenth-century France also attracted historical interest because it was a place in which economic changes transformed the whole society. New railroads and factories brought large-scale migrations into French cities. Historians in both Europe and America thus examined changes in the urban landscape and the impact of industrialization on working-class communities, as well as the early organization of unions, political parties, and socialist newspapers. The interest in early French labor history and industrialization nevertheless declined as economic concerns shifted to globalization and the problems of deindustrialization. The study of labor movements gradually gave way to new interests in transnational labor migrations and international trade, so that worker organizations in nineteenth-century France became less significant for social and economic historians.

The history of elite French culture, like the history of revolutions and early labor movements, also became more problematic. Historians had frequently been drawn into French cultural history through the novels of Stendhal, Honore de Balzac, Gustave Flaubert, and Victor Hugo. Cultural interests were shifting by the early twenty-first century, however, and cultural historians were challenged to explain how readers in modern, multicultural societies could learn useful insights from the "great books" of long-dead European male authors who often held demeaning views of women and non-European peoples. Similarly, the great French artists, from Jacques-Louis David to Eugène Delacroix, Gustave Courbet, Édouard Manet, and Paul Gaugin, began to seem less interesting when they were reexamined with careful attention to their views on women or Asian cultures or colonized people. The famous white men in nineteenth-century Paris had helped historians accumulate impressive forms of cultural capital, but this cultural wealth began to lose some of its intellectual value as cultural perspectives evolved.

Finally, historians had often studied nineteenth-century France because it offered provocative encounters with influential social theories. In the decades between 1820 and 1900, the French made major contributions to the emergence of modern nationalism and national identities. French society at the time was also the complex social context in which controversial thinkers such as Charles Fourier, Pierre-Joseph Proudhon, and Louis Blanc developed new critical theories about capitalism and its influence on modern politics. Equally important, French women challenged male political privileges and developed feminist cultural critiques, beginning with the political activism of Olympe de Gouges and expanding through the influential literary works of Germaine de Staël and George Sand. Despite this rich 
tradition of analyzing gender relations, women writers in nineteenth-century France became less helpful for modern theorists as feminism moved toward new psychological themes, drew upon (or challenged) twentieth-century poststructuralism, and developed new critiques of patriarchal social systems.

It would be easy enough to add other examples of the political, economic, cultural and theoretical issues that helped to sustain earlier interests in nineteenth-century French history, but the essential theme would remain the same: the cultural world in which historians are now working has moved away from many of the historical problems that used to carry scholars and students into the study of nineteenth-century France. Since historians are always drawn to subjects that seem important or relevant to their own concerns, a resurgent interest in the nineteenth century seems unlikely (especially in North America). I would nevertheless emphasize that many important questions in our present historical context can still be linked to the ongoing study of nineteenth-century France.

Authoritarian leaders who gain support by mobilizing populist and anti-foreign political movements pose a political challenge that connects contemporary democracies to postrevolutionary France. How did Bonapartist systems emerge in France after the great upheavals of 1789 and 1848? Why did former revolutionaries turn to authoritarian figures, and how did the two Napoleons convince so many people that a modern emperor could serve their interests more effectively than democratic legislatures and independent judicial systems? The nineteenth-century revolutions may now attract less research, but we still have good reasons to analyze the reactionary turn toward authoritarian regimes among people who responded with anger or fear to the disorienting social, political, and economic changes of earlier transitional times.

The migration of workers and displaced persons, which became very common in the nineteenth century, also raises historical issues that resonate in our present context. How did people respond to this migration and to the new interactions with immigrants? How did nineteenth-century cities develop multicultural neighborhoods, and how did new social tensions emerge as newcomers brought different languages, religions, and cultural traditions into older urban quartiers? How, too, did nineteenth-century workers respond to the growing concentration of wealth in nineteenth-century cities? There are numerous nineteenth-century French precedents for the growing economic disparities in twentyfirst century societies, and the political effects of such disparities can be better understood through more historical analysis of earlier capitalist wealth and economic hierarchies.

If we can turn back to the nineteenth century for new perspectives on French responses to revolutionary changes, migration, and the concentration of wealth, we can also recognize the critical insights of writers and artists who constantly questioned their own social world, even when they might be described as "privileged white men." Balzac's account of status-obsessed Parisians may well be as relevant today as it was in the 1830s; and Vautrin's ruminations in the 1834 novel Père Goriot still offer a starting point for critical thinking. "Honesty will get you nowhere," Vautrin explains. "Corruption is thick on the ground, talent rare ... So if you want to get rich quickly you either have to be rich to start with or appear to be so."4 French authors wrote about every human experience, ambition, and pain in the nineteenth century, and (going beyond the most famous writers) historians have found forgotten

\footnotetext{
${ }^{4}$ Honoré de Balzac, Old Man Goriot, trans. and notes by Olivia McCannon, introduction by Graham Robb (London: Penguin Books, 2011), 98-99.
} 
narratives by women, workers, and enslaved people who lived through violent revolutions and economic upheavals. Reading about their experiences gives new perspectives to people who feel overwhelmed by the political and economic problems of our own century.

Finally, the nineteenth-century tradition of critical theorizing about social and cultural conflicts offers good analytical methods for people to "think with," even when they think mostly about contemporary public and personal issues. We cannot understand modern nationalism, for example, without studying its nineteenth-century theorists; and we cannot imagine new social institutions without examining the perspectives of earlier reformers who wanted to change the undemocratic structures of nineteenth-century social life. I am therefore reaffirming the need for historical studies of nineteenth-century societies-including France-because the people of that era created social systems and ideologies that continue to influence all modern cultures. The global pathway to modern history passes straight through the nineteenth century. Although this period will never regain its former prominence in historical studies, it will remain an essential century for anyone who wants to think critically and creatively about modern global systems and the enduring, modern aspirations for human rights and democratic institutions. 


\title{
The Nineteenth Century in British History
}

\author{
Alex Chase-Levenson (University of Pennsylvania)
}

I $\mathrm{N}$ considering the broad health of a field of history, its fluxes and its flows, its overall balance and its future prospects, it is helpful to recall the French surgeon René Leriche's famous definition of what it means to be healthy: "life lived in the silence of the organs." ${ }^{1}$ In 2018, nineteenth-century British history's various organs might be emitting muted grumbles of distress - but no death rattles. The grumbles reflect certain asymmetries and very limited neglect. But this is a patient whose state is far from critical and whose prognosis is hopeful.

Is the magnet pulling all historians ever closer to the present stronger than the one pulling historians of a particular national history to the era in which that nation was most influential around the world? If not, then Britain's nineteenth century would be, historiographically speaking, in rude health. That is too cheerful a reading of the situation, yet the second magnet exerts at least a moderate pull. Compared to the national histories presented by others in this forum, Britain's nineteenth century has not seen anything like so dramatic a level of defection in terms of hiring, research, or interest.

One way to examine that question is to investigate recent hiring in the field. In examining the North American job market over the past seven years, I counted twenty-seven institutions that advertised a job in modern British history. The results of these searches suggest that the nineteenth century is holding its own: thirteen led to the appointment of a candidate whose research, broadly speaking, covers the nineteenth century. ${ }^{2}$ Three searches selected eighteenth-century experts, and ten ended with the hiring of twentieth-century specialists. Given that search committees typically comprise scholars from outside the field, these job statistics can be taken as a (very rough) indication that historians representing a range of specialties endorse nineteenth-century Britain as an important element of departmental coverage.

This general impression of sustained relevance for the nineteenth century is confirmed elsewhere. A similar picture emerges when one considers not simply those universities that have recently hired British historians but also the disposition of modern Britain specialists (junior and senior scholars alike) at a wider selection of universities. For the sake of creating a manageable sample, I surveyed the top fifty history graduate programs in the most recent ranking by US News and World Report (because of ties in those rankings, there are fiftytwo schools in the top fifty). ${ }^{3}$ Among them, four schools retain at least two modern Britainists on the faculty; nine do not have any specialists in the field. Focusing not just on a scholar's first book but also on her or his current research emphasis, I count five scholars whose research primarily concerns the eighteenth century, twenty twentieth-century experts, and twenty-three nineteenth-century specialists.

\footnotetext{
${ }^{1}$ Quoted in Georges Canguilhem, On the Normal and the Pathological, trans. Carolyn Fawcett (Dordrecht: D. Reidel, 1978), 46.

${ }^{2}$ I have included only searches whose results I have been able to ascertain.

${ }^{3}$ They are available at https://www.usnews.com/best-graduate-schools/top-humanities-schools/ history-rankings.
} 
Based on such a landscape, one cannot claim neglect of the nineteenth-century. Yet, it is important to note other signs that the once dominant position of the period within British studies is beginning to ebb. This is clearer on the level of anecdote, in the sense of a growing proportion of undergraduate students whose chosen paper and thesis topics skew to post1914 subject matters. The shift in emphasis can also be seen in the broad distribution of articles in the Journal of British Studies (JBS), which (excluding special issues focused entirely on one period) shows how other periods of the British past have been affected by the rapid growth of attention to recent history. Articles primarily focused on the twentieth century constituted 23 percent of those published between 1998 and 2003, and 33 percent between 2013 and 2018. The consequent declines in other periods have been moderate and evenly distributed, however-to the JBS's credit: articles focused on the nineteenth, eighteenth, and seventeenth centuries declined in terms of their relative share by about 2 percent over the course of the last two decades.

Why should we care about the fate of this one period of historical study? For one, Britain's nineteenth century unfolded across the globe. One ramification of British imperialism (formal and informal) is that, in intellectual terms, British studies complements many other fields. In 1999, a report on the state of the field by the North American Conference on British Studies (NACBS) warned that, as senior modern Britanists retired, scholars in other fields were often reluctant to replace them, put off by a sense that the field conjured images of "old men in tweed coats who still hanker after the stuffy and sexist atmosphere of the senior common room." " Both as a matter of demographic fact and as a matter of reputation (reflecting the growing centrality of non-Western locales within British studies), the edge of this critique has been blunted. Indeed, if the 1999 NACBS report saw the rise of nonWestern fields of history as a factor in the decline of British studies, modern British historians (and particularly scholars whose work focuses on Britain's imperial apogee in the nineteenth century) can today emphasize not simply their own merits but also their status as essential partners in inquiry with historians of Africa, South Asia, the Middle East, Latin America, and other regions of the world.

This collaborative potential applies not simply in regional terms but also thematical ones. Many of the phenomena of nineteenth-century British society are of special importance in a variety of transregional fields: the industrial revolution is central to histories of capitalism, and Britain's imperial brutality to historians of empire and race, whereas the efflorescence of Victorian print culture is crucial for literary scholars. As a study of political stability, Britain deserves attention as the only European country to avoid a revolution in the period between 1789 and 1914, as it moved toward mass democracy. From the original railway boom to the first world's fair, from imperial atrocities (with lingering aftershocks) to some of the first articulations of humanitarianism, a history of the world in the nineteenth century features a recurrence of British locales, themes, and concepts. The field can serve, as Guy Ortolano has observed, not as a "paradigmatic case" within global history "but nevertheless ... a significant one." 5

\footnotetext{
${ }^{4}$ Peter Stansky et al., "NACBS Report on the State and Future of British Studies in North America (1999)" (http://www.nacbs.org/archive/nacbs-report-on-the-state-and-future-of-british-studies).

${ }^{5}$ Guy Ortolano, "The Typicalities of the English? Walt Rostow, The Stages of Economic Growth, and Modern British History,” Modern Intellectual History 12, no. 3 (2015): 661.
} 
Compared to the slight decline in emphasis, mentioned earlier, on nineteenth-century studies in favor of the twentieth century, the global turn has brought about a greater degree of transformation in the field. On the one hand, the growth of imperial and transnational history has clearly been a progressive change, helping to transform nineteenth-century British history in terms of the sources, voices, and geographic regions given consideration. On the other hand, particularly in North America, the growing tendency to understand British history not just partially but predominantly through a global, imperial, and transnational lens means that historians have (very generally) begun to avoid narratives and topics that are delimited by national borders. The histories of enclosure, the Reform Crisis (1831-1832), the new Poor Law (1834), and the Chartist Movement, for example, are all directly relevant to modern crises of democratic politics and economic inequality. A few historians continue to work on these topics, but the most influential monographs written about them are still those that were published during the 1970s, 1980s, and early 1990s. A review by Maya Jasanoff of David Cannadine's recent Victorious Century (the nineteenth-century volume in Penguin's new History of Britain series) alluded to this historiographical state of affairs, noting that Cannadine's coverage of political history was "so old it's new again."

Nineteenth-century histories of wars, social movements, and domestic spaces retain a certain "relevance" in the present because of the influence of popular culture, especially the films and television series set in this period. Yet, however alluring Masterpiece Theatre might be, relying on the entertainment industry to generate academic interest ties scholarship not only to the whims of television but also to the public's greater enthusiasm for depictions of twentieth-century events. Indeed, such a bias does shape academic history in broad ways. Scholars may now recognize the revolutionary and Napoleonic conflict as the "first total war," but the number of conferences and symposia commemorating the bicentenary of their conclusion in 2015 were dwarfed by the roughly contemporaneous events dedicated to the centenary of World War I. ${ }^{7}$ The ubiquitous attention to World War II, both in popular culture and in popular history writing, is further evidence of this trend favoring the twentieth century. Winston Churchill is a conflicted and intriguing historical figure, to be sure, but when we expand our gaze, it is unclear why he should draw so much more popular (and historical) interest than the equally conflicted, idiosyncratic, and alcohol-loving William Pitt the Younger, who also led Britain through an existential crisis.

The implicit assumption of the grander stakes of twentieth-century histories is not exclusively a facet of political and social history, fields that have received waning attention in all national histories since the 1970s and 1980s. Major topics within the cultural history of nineteenth-century Britain-from the history of crime to the history of theatrical spectacle- have too often been primarily conceded to literary scholars. Whereas universities often have several professors of Victorian literature, few departments have multiple scholars of nineteenth-century British history — an imbalance that shapes in deleterious ways our understanding of numerous nineteenth-century cultural phenomena.

I make these points not to mourn the comparative hegemony of the nineteenth century within history departments that existed from the 1950s through the 1980s, a period marred by a lack of attention to imperial subjects and other marginalized voices. In fact, there is ample reason to expect that the current emphasis on "Britain and the World" will present numerous

\footnotetext{
${ }^{6}$ Maya Jasanoff's review appeared in The Guardian, Nov. 10, 2017.

${ }^{7}$ David Bell, The First Total War (New York: Houghton Mifflin, 2007).
} 
opportunities, not just for expanding our attention to regions of the world that have been previously neglected but also for bringing renewed attention to a diverse set of locales within Britain itself. In the tradition of Catherine Hall's Civilizing Subjects: Metropole and Colony in the English Imagination 1830-1867, with its layered history of Jamaica and the British Midlands, other locales and phenomena will continue to present similarly connected stories that integrate older scholarship and familiar characters and events within a wider circuit of intersections. ${ }^{8}$ The domestic history of Britain and the history of Britain within the wider world have been told together already, but this is a fruitful intersection that will generate much more scholarship.

Yet, even as we return to topics within the domestic history of Britain - now trained to recognize the implications of transnational networks - we should be equally engaged when the story remains local or national. Those Britons relatively untouched by global connections are nevertheless worthy objects of study. And even if we make the case that no human being is an island, certain historical actors were more rooted than others. What a waste it would be for E. P. Thompson to have rescued the "Luddite cropper" and the "'obsolete' handloom weaver ... from the enormous condescension of posterity," only for us to toss them back into obscurity captivated by the ostensibly greater "relevance" of the very recent past or the glamor of the boundary-crossing historical subject! ${ }^{9}$ To note that the histories of, for example, British drug consumption, evangelical revivalism, and regulation of prostitution can be told in both local and transnational registers does not mean we should always elevate the global frame of analysis.

As a historian of Britain in the world, I, too, have often privileged the voices of those who moved above those who stayed at home. Perhaps it is the conjuncture between extraordinarily dynamic national and transnational histories that can add urgency to the study of nineteenth-century British history. The period witnessed, after all, a domestic British history replete with political upheaval, economic drama, and cultural ferment, as well as a history of Britain in the world, in which imperialism led to global economic transformation, humanitarian catastrophes, and enduring inequalities. Indeed, this is a period and a place singularly positioned to attract undergraduate students and members of the wider public to the history of Britain, to the history of Europe, and to history itself. If part of the draw of the past is its combination of explanatory power and intriguing difference, of commonality and mystery, nineteenth-century Britain offers a particular appeal. In studying it, students in English-speaking areas around the world encounter a society that intrigues with its foreignness, and whose luminous authors (high and low) wrote in a language they find easily discernible and often delightful. At the same time, students come to understand that analyzing the relationship among the rise of industrial capitalism and imperial expansion, as well as of restrictive nineteenth-century conceptions of race, class, and gender, is an essential part of coming to terms with our own political moment.

From the hungry forties to the sensational sixties, from literature to political ideology, from architecture to painting, no cultural preoccupation had a stronger hold on the nineteenth-century British world than eclecticism. And, if the intangible good that can

\footnotetext{
${ }^{8}$ Catherine Hall, Civilizing Subjects: Metropole and Colony in the English Imagination 1830-1867 (Cambridge: Polity Press, 2002).

${ }^{9}$ E. P. Thompson, The Making of the English Working Class (New York: Vintage, 1966), 12.
} 
accrue from exposure to a little bit of everything struck the Victorians as self-evident, we, too, can use the heterogeneity of the period to broaden its appeal to a wide audience. The joy, dexterity, and social conscience of Dickensian prose is something we can highlight to showcase nineteenth-century dynamism. At the same time, Charles Dickens's misogynistic treatment of his wife and his morally repugnant blindspots to imperial abuses are equally essential for understanding the complexity of the period's cultural universe.

The humor of nineteenth-century melodramas, the evocative strangeness of preRaphaelite paintings, and the cluttered coziness of Victorian drawing rooms can and should impel interest in Britain's nineteenth century. So should the unflinching critical illumination of its vast inequities, cold complacencies, and stark brutalities. As our work dissects the linkages between the cozy and the calamitous, we can demonstrate the moral urgency of the latter and the appeal of the former while emphasizing the era's broad import to students, colleagues, and the general public. Like nineteenth-century history itself, our advocacy of this period should be eclectic and evolutionary, rooted and mobile. 


\title{
The History of War and Military Affairs
}

\author{
Roger Chickering (Georgetown University)
}

HERE has been no decline of research into the history of European warfare and mil-
itary affairs during the nineteenth century. This observation reflects a paradox, given
the sparsity of European wars during the era bounded by the Congress of Vienna and the outbreak of war in 1914. Like German history, however, the history of European military affairs in the nineteenth century has been governed by historical narratives of the twentieth century. If Adolf Hitler, the Third Reich, and the Holocaust stand at the culmination of the one narrative, the two great European wars of the twentieth century represent the telos of the other. But the similarities end there. Hitler has survived to energize a late twentieth-century narrative of German recovery and reunification, in which the civic management of memory and the legacy of National Socialism is a principal motif. By contrast, the historical narrative of European warfare has come effectively to an end in 1945. There has been no third world war in Europe, and even its prospect, which once threatened to bring the grand narrative of military history (and human history) to an apocalyptic climax, has receded. The success of the great European project has - so far-limited the history of armed conflict to peripheral regions like the Balkans and Northern Ireland, as the history of European warfare has modulated into a matter of technology and management. The results of this contrast have been to lure historians of Germany out of the nineteenth century, off the Sonderweg (special path), away from the antecedents of the Third Reich, and toward the history of its memory after 1945. Meanwhile, the quiet European battlefields of the postwar era have encouraged scholars of European military history back into the nineteenth century to explore the antecedents of the military catastrophes of the following century.

"Total war" represents the telos of the master narrative that continues to inform modern European military history. Devising anything better than a rough definition of total war has frustrated generations of scholars. It suffices here to describe it as an ideal type, a model of warfare in which practical distinctions vanish between soldiers and civilians, the military and civilian spheres of society. In their roles as providers of material and moral support, civilians became as essential to the outcome of war as soldiers; and they became no less legitimate or vulnerable as targets of military violence, be it in the form of bombardment, starvation by blockade, or ideologically mandated extermination at the hands of occupying forces. ${ }^{1}$

This understanding of total war, which, in most accounts, has found its closest historical approximation in World War II, has, in turn, put two related orders of questions at the center of the historiographical agenda since 1945 . The first order, which might be called diachronic, pertains to questions of when European warfare began historically to display features that developed into the "totality" of the twentieth century. The wars of the French Revolution and Napoleon generally figure large in this connection. The moral foundations of total war were thus laid in the levée en masse, conscription, and the introduction of a regime of gender roles that invoked images of the family and that featured men as soldiers in defense

\footnotetext{
${ }^{1}$ Roger Chickering, "Total War: The Use and Abuse of a Concept," in Anticipating Total War: The German and American Experiences, 1871-1914, ed. Manfred Boemeke, Roger Chickering, and Stig Förster (Cambridge: Cambridge University Press, 1999), 13-28.
} 
of the fatherland and women in subordinate, though essential supporting roles. ${ }^{2}$ The complement of these institutions appeared several decades later in European industrialization, which made it materially feasible for societies to feed, clothe, transport, arm, and organize themselves for this new kind of mass warfare.

A second order of questions raised by the narrative of total war might be called synchronic, for these address the social, political, and cultural mechanisms, the institutions and practices, that enabled societies to mobilize comprehensively and to turn civilians, male and female, into willing participants in warfare. These questions have perforce emphasized the reciprocal relations of war and society, and they have demanded that historians, too, cultivate an understanding of warfare that is confined neither to the battlefield nor to events between the commencement and cessation of military operations.

German scholars have been prominent in pursuing such a broad approach to the history of warfare. The reasons have had to do with the centrality of nineteenth-century developments in Central Europe to the military history of the twentieth century. They also reflect the institutional support that this inclusive vision of military history has enjoyed in Germany, particularly in the Military History Research Office in Freiburg (now the Center for Military History and Social Sciences of the Bundeswehr in Potsdam), the Institute for the Military History of the German Democratic Republic (GDR) in Potsdam, and the German Working Group for Military History. When this last group convened a conference in 1998 to consider the question "What is Military History," the participants compiled a comprehensive answer, whose elements included operational history, political history, social history, economic history, the history of technology, cultural history, and gender history. ${ }^{3}$ The presence of non-Germans at this and many other conferences on German soil reflected the international appeal of this "new" military history of war and society, particularly in the United Kingdom and North America, where scholarly journals are devoted to it as well.

Although this scholarship has hardly been confined to the nineteenth century (or to warfare in Europe), the European nineteenth century has been the setting for a great deal of it. In the reigning narrative, the forces that culminated in total war during the twentieth century gestated in the nineteenth. The military implications of political upheaval, technological advance, and social transformation became evident in Europe during brief wars in the middle of the century, which were fought by armies that had been conscripted in the name of the nation, armed with mass-produced repeating weapons, and transported to the battlefield by rail. ${ }^{4}$ To discerning observers, however, the simultaneous Civil War in North America provided the most accurate portents not only of where the resulting battlefield dynamics might lead, but also of the likely impact of a long industrial war on civilian society. ${ }^{5}$

\footnotetext{
${ }^{2}$ Karen Hagemann, "Männlicher Muth und Teutsche Ehre": Nation, Militär und Geschlecht zur Zeit der Antinapoleonischen Kriege Preußens (Paderborn: Schöningh, 2002); Karen Hagemann, Alan Forrest, and Michael Rowe, eds., War, Demobilization and Memory: The Legacy of War in the Era of Atlantic Revolutions (Basingstoke: Palgrave Macmillan, 2016).

${ }^{3}$ Thomas Kühne and Benjamin Ziemann, eds., Was ist Militärgeschichte? (Paderborn: Schöningh, 2000).

${ }^{4}$ These wars are the subject of excellent newer historical studies: Dennis Showalter, The Wars of German Unification (London: Bloomsbury, 2004); Geoffrey Wawro, The Austro-Prussian War: Austria's War with Prussia and Italy in 1866 (Cambridge: Cambridge University Press, 1997); idem, The Franco-Prussian War: The German Conquest of France in 1870-1871 (Cambridge: Cambridge University Press, 2005).

${ }^{5}$ Stig Förster and Jörg Nagler, eds., On the Road to Total War: The American Civil War and the German Wars of Unification (New York: Cambridge University Press, 1997).
} 
The most innovative scholarship on the military history of nineteenth-century Europe has focused on the era that followed the mid-century wars of national unification. At issue has been the cultivation of martial attitudes, particularly the deference to military values in civilian society at large during the decades before World War I. Although its origins lie in the middle of the nineteenth century, the term militarism has commonly attached to this problem. The historical focus of scholarship broadened after 1945, from an analysis of the influence of soldiers in political councils to a broader study of social trends. The most comprehensive synthesis of this work at the end of the last century can be found in the work of West German historians who, in the 1970s and 1980s, were loosely associated with the effort to define history as a Sozialwissenschaft (social science). Hans-Ulrich Wehler, their most outspoken advocate, argued that German militarism represented both the symbol and fundamental cause of Germany's failed development along a Sonderweg into the modern era. The basic pathology of German history lay in the political survival of the "premodern" aristocratic Prussian military caste into the modern era of industrialization and popular government. This development not only ensured the persistence of authoritarian political institutions, but also led to the systematic inculcation of military attitudes and authoritarian values throughout civilian society via schools and universities, conscription, military reserves, veterans' groups, and many other voluntary associations. "In no other Western society," wrote Wehler in 1995, "did the military occupy such a high position in the hierarchy of prestige as in Germany; nowhere else did social militarism exercise such a profound and durable influence."6

This comparative claim remained unsubstantiated in Wehler's account, although the evidence suggests that his generalization was largely apt. ${ }^{7}$ The more basic limitations of his understanding of militarism inhered in the broad social approach to German history that he called Gesellschaftsgeschichte (history of society). In its emphasis on social structures, institutions, and political manipulation by social elites, this approach offered little insight into the cultural dimensions of German militarism - the collective attitudes and ideas, values and practices, that this term connoted, or the reasons for their popularity. As the attack on Wehler's approach developed generally in the wake of the "cultural turn" at the end of the last century, the scholarship on militarism turned from an emphasis on military institutions as the wellspring of militarism to an analysis of the broader reception, meanings, and diverse functions of military ways of thinking and behaving. Stig Förster's dissertation, for example, introduced the concept of a "double militarism," one of whose components undermined the other. Förster wrote of an aggressive, uncompromising variety of militarism, which middle-class civilian leaders of radical nationalist organizations embraced as they challenged the social and political power of "preindustrial elites" whose power militarism had been thought to buttress, in the traditional analysis. ${ }^{8}$ Other scholars focused on the currency

\footnotetext{
${ }^{6}$ Hans-Ulrich Wehler, Deutsche Gesellschaftsgeschichte: Von der „Deutschen Doppelrevolution” bis zum Beginn des Ersten Weltkrieges 1849-1914 (Munich: C. H. Beck, 1995), 1126. See also Detlef Vogel, "Militarismusunzeitgemäßer Begriff oder modernes historisches Hilfsmittel? Zur Militarismuskritik im 19. und 20. Jahrhundert in Deutschland," Militärgeschichtliche Mitteilungen 39, no. 1 (1986): 9-35.

${ }^{7}$ Roger Chickering, "War, Society, and Culture, 1850-1914: The Rise of Militarism," in The Cambridge History of War, vol. 4, ed. Roger Chickering, Dennis Showalter, and Hans van de Wen (Cambridge: Cambridge University Press, 2012), 119-41.

${ }^{8}$ Stig Förster, Der Doppelte Militarismus: Die deutsche Heeresrüstungspolitik zwischen Status-quo-Sicherung und Aggression 1890-1914 (Stuttgart: Franz Steiner, 1985).
} 
of military attitudes in broad sectors of civilian society, concluding that these attitudes had found reception among groups whose civic culture was, for a variety of independent reasons, congruent with military values. ${ }^{9}$ That such patterns prevailed in other countries as well was evident in Jakob Vogel's comparative inquiry into the civic rituals of military festivals in Germany and France, which he investigated in light of "folklore militarism," and in Jan Rüger's complementary study of "folklore navalism" in Germany and Britain. ${ }^{10}$

This work anticipated a more fundamental reorientation toward the historical problem of martial attitudes in the nineteenth century. At issue now are the basic dichotomies on which traditional understandings of militarism have rested: the analytical distinction between the military and civilian spheres of society, as well as the proposition that military culture bred in military institutions, then seeped into civil society. This dichotomy between military and civilian realms clashed with the concept of total war, and it provoked new lines of inquiry into the civilian sources of military attitudes. Scholars have begun to employ, in this connection, the term bellicism, which came into general usage in the 1990s to suggest broader ways in which war figured in civic cultures during the nineteenth century. Jörn Leonhard's comparative survey of France, Germany, Great Britain, and the United States has been seminal. Here he analyzed "the connections between perceptions of warfare, the interpretive appropriation of these perceptions, and representations of the nation," to show how, in all four countries, military "violence proved to be constitutive of the political, particularly for the political space of the nation." 11 The practical analytical consequence of this approach has been to emphasize the centrality of warfare and martial attitudes to the definition and cultural experience of the nation, from the moment of its birth. ${ }^{12}$

A wealth of new scholarship has explored this proposition, particularly in the case of Germany in the nineteenth century, as discourses of war and nationality developed together. "War" meant above all the Anti-Napoleonic Wars, the memory of which figured decisively in the political discourse after 1815 and then in shaping the civic culture that emerged after $1871 .{ }^{13}$ The central topos in this discourse was the Volk in Waffen (nation-in-arms), which, particularly in the eyes of liberal and democratic German nationalists of the early nineteenth century, had participatory, if not democratic overtones, and which mandated a national militia as the military complement of constitutional government and parliamentary institutions. During the turbulent decades of the mid-century, the most aggressive advocates of war in the name of national unity were these nationalists and the voluntary associations - the Gesangvereine, Schützenvereine, Turnvereine (singing, shooting, and gymnastics clubs), and many other varieties - in which this belligerent sentiment was cultivated. ${ }^{14}$ These were

\footnotetext{
${ }^{9}$ Benjamin Ziemann, "Sozialmilitarismus und militärische Sozialisation im deutschen Kaiserreich 1870-1914," Geschichte in Wissenschaft und Unterricht 53, no. 3 (2002): 148-64.

${ }^{10}$ Jakob Vogel, Nationen im Gleichschritt: Der Kult der "Nation in Waffen" in Deutschland und Frankreich (Göttingen: Vandenhoeck \& Ruprecht, 1997); Jan Rüger, The Great Naval Game: Britain and Germany in the Age of Empire (Cambridge: Cambridge University Press, 2007).

${ }^{11}$ Jörn Leonhard, Bellizismus und Nation: Kriegsdeutung und Nationsbestimmung in Europa und den Vereinigten Staaten 1750-1914 (Munich: De Gruyter Oldenbourg, 2008), 9, 820.

${ }^{12}$ Nikolaus Buschmann and Dieter Langewiesche, eds., Der Krieg in den Gründungsmythen europäischer Nationen und der USA (Frankfurt/Main: Campus, 2003).

${ }^{13}$ Karen Hagemann, Revisiting Prussia's Wars against Napoleon: History, Culture and Memory, trans. Pamela Selwyn (Cambridge: Cambridge University Press, 2015).

${ }^{14}$ Nikolaus Buschmann, Einkreisung und Waffenbruderschaft: Die öffentliche Deutung von Krieg und Nation in Deutschland 1850-1871 (Göttingen: Vandehoeck \& Ruprecht, 2003); Dietmar Klenke,
} 
not military associations and, it appears, their leaders had not been exposed to military values by dint of service in the regular armies of the German states. ${ }^{15}$ In fact, war in the name of the nation-in-arms was, precisely because of its revolutionary and democratic civic implications, anathema to the monarchs and aristocratic leaders of professional armies in Germany. To this extent, the real fount of martial thinking lay in civilian, not military institutions.

Recent scholarship has argued persuasively that the resolution of this paradox came with the Wars of German Unification (1864-1871). The key here was that reform of the Prussian army during the early 1860s had melded the contending elements in the civic discourse, as it produced an army of short-term conscripts led by a largely aristocratic corps of professional officers. The fact that military institutions and attitudes subsequently enjoyed such enormous prestige in the German empire was due to the spectacular success of such armies during the mid-century wars. It rested as well, however, on what Frank Becker has, invoking Hegel, called a "synthetic militarism," which was based on a modern combination of civic participation and professional leadership. ${ }^{16}$ The synthesis comported both with traditional understandings of monarchical authority and the civic values associated with the nation-in-arms, progress, and achievement. Jörn Leonhard has written in this connection of varieties of "national bellicism or bellicistic nationalism," and he has found ample evidence of them after 1871 in all four of the countries he surveyed. ${ }^{17}$

Declining interest in European history in the nineteenth century is doubtless a matter of legitimate concern. It is worth noting, however, that the number of articles and book reviews in Central European History, or the number of papers presented at the annual meetings of the German Studies Association, may not be the most reliable indices of trends in all fields of nineteenth-century history. ${ }^{18}$ In the case of military history, a perusal of other scholarly journals and the programs of other professional organizations suggests that, far from declining, interest in the nineteenth century remains as vibrant as the scholarship it has generated.

\footnotetext{
"Nationalkriegerisches Gemeinschaftsideal als politische Religion: Zum Vereinsnationalismus der Sänger, Schützen und Turner am Vorabend der Einigungskriege," Historische Zeitschrift 260, no. 1 (1995): 395-448. ${ }^{15}$ Mark Hewitson, The People's Wars: Histories of Violence in the German Lands, 1820-1888 (Oxford: Oxford University Press, 2017), 59.

${ }^{16}$ Frank Becker, Bilder von Krieg und Nation: Die Einigungskriege in der bürgerlichen Öffentlichkeit Deutschlands 1864-1913 (Munich: De Gruyter Oldenbourg, 2001).

${ }^{17}$ Leonhard, Bellizismus, 741-818.

${ }^{18}$ David G. Blackbourn, "Honey, I Shrunk German History," German Studies Association Newsletter 38, no. 2 (2013-2014): 44-53.
} 


\title{
A "Jewish Sattelzeit"? Recasting an Era of Upheaval and Transformation
}

\author{
Simone Lässig (German Historical Institute, Washington, D.C.)
}

$\mathrm{T}$ HE eighteenth and nineteenth centuries occupy a central position in the development of modern Judaism. The century from roughly 1770 to 1870 saw the emergence of the pluralistic faith we know today, as well as the end of civil and political restriction on Jews in most of Europe. The "Jewish Enlightenment" of the eighteenth century - the Haskalah - opened an era of critical self-examination that, against the backdrop of political, social, and economic revolutions across Europe and the Atlantic world, culminated in the articulation of the Reform and Orthodox movements. This internal debate within European Jewry coincided with a debate among Jews and gentiles alike on the civic status of the Jews. Scholars in Jewish history and Jewish studies have not given priority to this period in recent years, but a steady stream of publications attests to the fact that this transitional era remains a fruitful area of research. ${ }^{1}$

At the same time, many of those publications confirm what can also be observed at conferences and congresses: Jewish history is mainly written by specialists for specialists. Scholars studying the Haskalah have engaged with research on other facets of the European Enlightenment in an inspiring way, yet research on the nineteenth century has become increasingly inward-looking. ${ }^{2}$ Focusing on the internal dynamics of change, recent research tends to center on Jewish agency and to concentrate on specifically Jewish spheres of experience. This trend is, in large part, a response to the regrettable lack of interest in Jewish history on the part of other Europeanists. Not surprisingly, then, specialists in Jewish history who work on the nineteenth century have shown little interest in general historical developments and phenomena, and they have rarely ventured into comparative research or entangled histories. In short, the questions driving research on nineteenth-century European Jewry largely stand apart from those that engage historians of nineteenth-century Europe. For their part, specialists in nineteenth-century history seldom consider Jews except in terms of their minority status. With a few notable exceptions, historians of the nineteenth century have not asked whether the experiences of European Jewry might illuminate developments that affected the rest of European society.

The problem is not that a particular century is disappearing, but rather that the boundary between a subfield of European history and the field of European history in general is not

A special thanks to David Lazar of the German Historical Institute Washington, D.C., who not only carefully edited this essay, but also translated parts of it.

${ }^{1}$ Shmuel Feiner, The Origins of Jewish Secularization in Eighteenth-Century Europe (Philadelphia: University of Pennsylvania Press, 2010); John M. Efron, German Jewry and the Allure of the Sephardic (Princeton, NJ: Princeton University Press, 2015). Efron's study is a rare example of a Jewish history that is embedded in more general developments of the time.

${ }^{2}$ One of a small handful of exceptions is Till van Rahden, Jews and Other Germans: Civil Society, Religious Diversity, and Urban Politics in Breslau, 1860-1925 (Madison: University of Wisconsin Press, 2008). On Haskalah and the Enlightenment, see David Sorkin, The Religious Enlightenment: Protestants, Jews, and Catholics from London to Vienna (Princeton, NJ: Princeton University Press, 2008); Shmuel Feiner, The Jewish Enlightenment (Philadelphia: University of Pennsylvania Press, 2004). 
disappearing in either our research or the textbooks and instructional materials we use in teaching. The lack of exchange across this boundary is especially striking in the case of German-speaking Central Europe. The Haskalah began within the Jewish communities of Central Europe, and it was above all the Jews of Central Europe who set the terms of religious and theological debate within European Jewry during the nineteenth century. Central European Jews were also arguably much more successful than their coreligionists elsewhere in Europe in securing a place for themselves in the new sociopolitical order that took shape in the decades after 1800. The social ascent of the Jews during the nineteenth century, though not the internal debates that accompanied it, remains a topic of concern to historians of Germany, even if they are less interested than before in viewing the status of the Jewish minority as evidence for or against a German Sonderweg (special path). In short, specialists in Jewish history and Central European history could have much to discuss, if only they recognized more fully the overlap in their interests. Thus, the question I want to pose here is not how we might be able to give new impetus to the study of the nineteenth century within the field of Jewish history, but rather how we can bring Jewish history and Central European history into productive dialogue. To suggest some of the potential gains closer integration of the two fields might bring, I will outline a broad research problem that strikes me as particularly promising - not least because it touches on the contemporary and scholarly relevance of the period we are considering in this forum.

The ever-growing complexity and rapid change that has been a hallmark of contemporary life suggests a striking parallel to the Europe of the early nineteenth century. Long trusted and trust-inspiring structures, institutions, and authorities - in politics and economic life, as much as in culture and the media- have lost legitimacy. Many people are searching for orientation and responses to new, hard-to-grasp challenges. The resurgence of populism, for instance, is grounded, to a large extent, in the search for guidance in an increasingly unpredictable world. As uncertainty grows, so, too, does the demand for coping strategies.

As singular as the challenges of the present might be, the challenges nineteenth-century Europeans had to master, in particular during the Sattelzeit at the turn from the eighteenth century to the nineteenth, present intriguing parallels. Much like the present, the Sattelzeit was a period of upheaval, a time when the legal, social, cultural, and knowledge orders that had structured people's lives for many generations rapidly lost meaning. Hitherto stable institutions and frames of reference such as religion and estate (Stand) lost their allencompassing and obligatory character. Seemingly eternal truths became subject to critical scrutiny in light of reason; established cultural hegemonies began to unravel; long important transregional networks were collapsing. The dissolution of the network of religious learning, trade, and elite exchange that had connected Yiddish-speaking Jewry in Central and Eastern Europe for centuries is just one of many examples during the Sattelzeit of the unraveling of once strong social bonds. Making these parallels clear and vivid to our colleagues and students is crucial if we historians of the nineteenth century want to put to rest the notion that the period is of little interest in trying to make sense of the present. As a religiously defined group, European Jews were particularly affected by the upheavals of the Sattelzeit, but their experience was also paradigmatic in many respects. ${ }^{3}$ Thus, early nineteenth-century

\footnotetext{
${ }^{3}$ David Sorkin, The Transformation of German Jewry, 1780-1840 (Oxford: Oxford University Press, 1987); Simone Lässig, Jüdische Wege ins Bürgertum: Kulturelles Kapital und sozialer Aufstieg im 19. Jahrhundert (Göttingen: Vandenhoeck \& Ruprecht, 2004).
} 
Jewish history can be used as an interpretive lens for exploring historical experiences of contingency, as well as the coping strategies social groups develop when confronted with profound social change and a devaluation of traditional cultures.

To flesh out that argument, I will explain, first, why the advent of modernity was a significant challenge for European Jewry and, second, why the experiences of the Jews are relevant to writing the history of that remarkable period of transition. I will then outline the reasons why a relational history that entangles Jewish history with other histories and that moves beyond the Leitkultur paradigm might help us recognize phenomena that get overlooked when we rely on analytical models that reinforce the idea that German Jews adapted to a "majority culture."

Although early modern Jewry had repeatedly experienced moments of cultural transfer, the Ashkenazi world nonetheless remained into the eighteenth century a comparatively autonomous and stable structure. ${ }^{4}$ Neither the autonomy of Jewish communities nor the all-encompassing reach of religion within them was entirely an anomaly in Europe's corporate societies, but the Lebenswelt that European Jews had formed around the Halakah was nonetheless unique. ${ }^{5}$ The challenges that came with the advent of modernity were thus particularly formidable for Central European Jewry, and they posed a deep threat to their continued existence as a distinctive and cohesive social group. The rationalism of the Enlightenment and the process of functional differentiation between the religious and the secular called into question the foundations of Jewish life. What it meant to be Jewish was no longer defined by religious law. Being Jewish became a matter of discussion, decision, and individual choice. And discussion about that choice was influenced by ideas developed outside the Jewish community-ideas, for example, about citizenship and nationhood, as well as about civilizing internal and external Others.

At a time when familiar structures of social order, religion, and culture were unraveling for many contemporaries, and when Jews and enlightened representatives of German states were addressing the question of what it meant to be citizens, Jews were also asking themselves what it meant to be Jewish in the emerging new sociopolitical order. The Reform movement and Orthodoxy were two of the responses to that question. The analysis of the coping strategies that took shape through a process of give-and-take between rural Jews and their "up-todate" (zeitgemäß) urban brethren can shed new light on processes of transformation in general, and on the role played by religion in particular. This seems especially compelling when considering that these coping strategies eventually facilitated, or at least contributed to, a remarkable social mobility over the course of two or three generations and, at the same time, fostered new forms of belonging and Jewishness. Using Jewish coping strategies and experiences of upheaval as a prism to analyze how people managed to navigate rupture and drastic change might also illuminate how discourses within and between social groups are shaped or influenced by external forces.

Scholars in the field of Jewish history have all too often neglected the fact that, as the old corporate society gave way to a new social order, Jews and gentiles in German-speaking

\footnotetext{
${ }^{4}$ Feiner, Origins.

${ }^{5}$ David B. Ruderman, Early Modern Jewry: A New Cultural History (Princeton, NJ: Princeton University Press, 2010).
} 
Europe found themselves confronted with the challenge of coming to terms with diversity. ${ }^{6}$ The search for norms and values that might provide a measure of social cohesion gave rise to a wide-ranging discussion of the civic position and "civil improvement" of the Jews after 1780. That discussion centered on the question of how to reshape the habits, attitudes, beliefs, and occupational structures of the Jewish "nation," which, at the time, was widely depicted as morally depraved, uncultivated, and unproductive. In many German (and other European) states, government officials initially developed a conditional and collective approach. They saw the Jews as an ideal test case for their concepts of citizenship and civility: if such a "nation" resistant to change could be refined and morally regenerated, they argued, almost any group could. ${ }^{7}$ This universal credo was closely connected to a belief that enlightened European bureaucrats shared with new social elites, including Jewish ones, namely, the belief that "cultivated," presumably morally superior individuals had a duty to educate and "civilize" groups at a supposedly lower level of cultural development. ${ }^{8}$ This outlook was patronizing but also pathbreaking. It rested on the completely novel assumption that Jews, Central Europe's most significant internal Other, had the potential to advance socially and to participate in the emerging civil society. That assumption went hand-in-hand with opposition to all manifestations of social particularism, the preeminent example of which was premodern Jewry. For the Jews of German-speaking Central Europe, in other words, accepting the state's offer of civic enfranchisement and emancipation also meant accepting the expectation and de facto requirement that they give up the familiar, clearly defined position they had held in the premodern corporate social order. This chapter of German-Jewish history thus points to a challenge all modern and postmodern societies have been facing ever since: navigating between the universal and the particular to define the bases of inclusion and exclusion.

How the Jews of German-speaking Europe were able to transform fundamentally their social profile and self-definition as a group in the course of only three generations remains an intriguing question. Although scholars in the field of Jewish history have started to reevaluate critically concepts such as assimilation, acculturation, and integration, the dominant line of scholarly interpretation still contends that they adapted to the expectations and norms of nonJews. Societies and social milieus do not, however, transform themselves simply by adopting alien practices and norms. ${ }^{9}$ They also make use of established frames of reference to assess and adapt new values or ways in light of cultural knowledge already at their disposal. Recent research on German-Jewish history that underscores Jewish agency suggests that religion provided such a frame, and thus allowed for innovation while preserving a meaningful sense of belonging. ${ }^{10}$ Many European gentiles, as well as many Jews, saw premodern/rabbinic

\footnotetext{
${ }^{6}$ See the following forum: Till van Rahden, Anthony Steinhoff, and Richard F. Wetzell, eds., "Diversity in German History," Bulletin of the German Historical Institute 61 (2017): 25-134.

${ }^{7}$ Ronald Schechter, Obstinate Hebrews: Representations of Jews in France, 1715-1815 (Berkeley: University of California Press, 2003).

${ }^{8}$ Jonathan M. Hess, Germans, Jews, and the Claims of Modernity (New Haven, CT: Yale University Press, 2002).

${ }^{9}$ See, e.g., Steven Aschheim, “German History and German Jewry," Leo Beck Institute Yearbook 43 (1998): 315-22; Jeremy Cohen and Moshe Rosman, eds., Rethinking European Jewish History (Oxford: Littman Library of Jewish Civilization, 2009); Till van Rahden, "Jews and the Ambivalences of German Civil Society, 1800-1933," Journal of Modern History 77, no. 4 (2005): 1024-47.

${ }^{10}$ Benjamin M. Baader, Gender, Judaism, and Bourgeois Culture in Germany, 1800-1870 (Bloomington: Indiana University Press, 2006); Lässig, Jüdische Wege, 2004.
} 
Judaism as hostile to progress, but it nevertheless became a decisive cultural resource for facilitating social change and even advancement, while providing stability during the Sattelzeit. ${ }^{11}$ Forward-looking Jewish thinkers made it a means for culturally translating novel frames of orientation, such as the concept of Bildung, and new bürgerliche patterns of conduct. The remarkable social advancement of nineteenth-century German Jews suggests, in short, that further research into the transformative potential of religion could be a fruitful line of inquiry beyond Jewish history. The bodies of knowledge that various Jewish, Catholic, and Protestant religious actors drew upon in grappling with crisis and in adapting to a new social reality could be an intriguing subject for a relational history of the Sattelzeit in Central Europe.

"Adapting" in this instance did not mean simply copying. It was often a process of creative participation in knowledge production and cultural translation. Even if they had wanted to, Jewish thinkers could not simply take their cue from "German society" or the Bürgertum, as is still often assumed in the scholarly literature. There was no Leitkultur for Jews to follow when they began to move across corporate and religious boundaries. The Sattelzeit was a period of cultural (re-)formation, and neither a clearly identifiable majority society nor a clearly defined notion of "Germanness" existed at the opening of the nineteenth century. The cultivated middle class had only just begun to take shape, and Jews - so far as their limited numbers and the constraints of social hierarchy allowed-were soon actively contributing to the formation of a middle-class culture and society. A crucial element of that contribution was the creation or reshaping of genuinely Jewish spaces, like religious societies (hevrot) and synagogues. Here we can observe fascinating parallels to the values, knowledge orders, and aesthetics (for instance, of listening) that were shaping profane spheres of middle-class life.

It should be obvious that we will not fully grasp the complexity and the contentious character of these processes until we move beyond applying concepts that presuppose dichotomies between putative majority and minority groups. Because such concepts tend to essentialize cultural differences, they obscure rather than illuminate the emergent character of cultures and, in the case of the early nineteenth century, the challenges with which many social groups had to cope during the Sattelzeit. When the old social order started to crumble in the late eighteenth century, there were many relatively autonomous and separate cultures. Far-reaching political, economic, and social change increased contacts and competition among those cultures, but it also opened the way for reciprocal influence and cultural exchange. ${ }^{12}$ Social upheaval and structural transformation created opportunities for formerly underprivileged and excluded groups to participate in forming new cultures, and to make their way up the social ladder. From this perspective, the example of the Jews suggests a promising line of inquiry for analyzing how other social and cultural groups in Central Europe responded to the challenges of nascent modernity.

More generally, the "Jewish Sattelzeit" offers a promising point of departure for studying strategies that enable individuals and groups to make sense of a rapidly changing world and to develop new concepts of the future. Analysis of the interplay of innovation and tradition

\footnotetext{
${ }^{11}$ Steven Aschheim, The Modern Jewish Experience and the Entangled Web of Orientalism (Amsterdam: Amsterdam University Press, 2010); Simone Lässig, "Als der Talmud peinlich wurde ... Über die Bildung der Sinne im Judentum des 19. Jahrhunderts," in Sinngeschichten. Kulturgeschichtliche Beiträge für Ute Daniel, ed. Christian Frey et al. (Cologne: Böhlau 2013), 139-51.

${ }^{12}$ Sorkin, Religious Enlightenment.
} 
during periods of uncertainty is a line of inquiry that might be worth pursuing when studying other groups. A related set of questions centers on the transformation of traditional knowledge orders and the sociocultural consequences of such transformations. Debates on the meaning and relevance of religious law (Halacha), for instance, had direct bearing on competing claims to leadership and authority within Jewish communities. The example of Central European Jewry suggests that religious groups and denominations that contemporaries deemed to be "old fashioned" and opposed to modernity were, in fact, as actively involved in creating transformative knowledge as their more "progressive" counterparts. The rivalry between self-styled advocates of progress and defenders of tradition draws our attention to the forms of populism, populist arguments, and populist mobilization-a subject of obvious present-day interest. These examples only hint at the rich potential this dynamic era, which was shaped as much by contingency and anxiety as by vitality and optimism, offers to us and our students if we want to think historically about very urgent contemporary issues. 


\title{
Celebrating "Boring" Ideas in the Age of Impatience: The Nineteenth Century in Intellectual and Cultural History
}

\author{
Suzanne Marchand (Louisiana State University)
}

$\mathrm{I}$ F Eric Hobsbawn had lived long enough to write a survey of the early twenty-first century, he might well have titled it "the age of impatience." ${ }^{1}$ We (and even more so our students) want immediate responses to our text messages and emails, and brief, punchy answers to our questions. Presses want shorter books; the "news" has been reduced to tweets. We do not want to wait six hours for a proper stew to cook; we do not like Max Weber's advice that politics is a process of boring hard boards. Nor are we comfortable with in-betweens: legislation that goes halfway toward the solutions we advocate, people who are free of some but not all prejudices, starting salaries that are not sufficient to satisfy all our desires. Too often we tend to criticize without putting our own shoulders to the wheel, or simply despair rather than hope. We do not inhabit an age conducive to admiring, or perhaps even taking seriously, the doggedly diligent, long-winded, semi-progressive, naively confident nineteenth century. It has acquired what is, in our "age of impatience," a lethal epitaph: it has become boring.

Why this holds true today for intellectual and cultural historians-especially those of the younger generation - is strongly related to what others in this forum have said about each of the national traditions. Right or wrong, we no longer believe in some of the "big picture" narratives that once made the nineteenth century so resonant: the possibility of reaching full equality through revolution, the Sonderweg, the inevitable evolution of democratic nationstates, the "Western tradition." We are thus embarrassed by a century frequently summed up by a panoply of boring "isms" - imperialism, nationalism, capitalism-none of which seems to have gotten us anywhere, not even into the "interesting" disasters of the twentieth century. This embarrassment might be understandable, but it has also become corrosive. ${ }^{2}$ It has contributed to the sense that only extremes are interesting, that only the impeccably pure of heart are worthy of praise, that only in the last ten to fifteen years has anyone really achieved moral rectitude. We need not, and should not, airbrush the nineteenth century, but we need to counter embarrassment with passionate teaching and scholarly advocacy, and use our humanistic tools - critical reading, careful contextualization, empathy - to recover some of the deep appreciation, positive or negative, that my generation's teachers felt for this world of incomplete, "boring" moderns.

How and when did this "embarrassment" begin? In retrospect, 1989 seems to be the proper starting point, as I can adduce directly from my own experience. It was in that year, with a series of fantastically rich undergraduate and graduate courses in

\footnotetext{
${ }^{1}$ See Eric Hobsbawm, The Age of Revolution (New York: New American Library, 1962); idem, The Age of Capital, 1848-1875 (New York: Scribner, 1975); idem, The Age of Empire, 1875-1914 (New York: Pantheon Books, 1987); idem, The Age of Extremes: The Short Twentieth Century, 1914-1991 (London: Michael Joseph, 1994).

${ }^{2}$ Cf. Suzanne Marchand, "Embarrassed by the Nineteenth Century," in Consortium on Revolutionary Europe, 1750-1850: Selected Papers, 2002, ed. Bernard Cook et al. (Tallahassee, FL: Consortium on Revolutionary Europe, 2004), 1-16.
} 
nineteenth-century intellectual history, philosophy, literature, and art behind me, that I went to Berlin to do my dissertation research and saw the Wall fall. I did not realize at the time that this was not only the beginning of the end of the Cold War but also the beginning of a shift in historical focus, away from the narratives mentioned above, and toward new passions, evident in magnificent new explorations of the nuanced non-teleologies of the early modern era, the diverse interactions between Europe and Asia, and the peculiar intellectual formations of the twentieth century. ${ }^{3}$ One could perhaps say that, while modernism lasted, with all its abstract utopias, we could not yet achieve critical distance from it, but when the fall of the Berlin Wall finally crushed it, younger scholars in particular felt driven to study its prehistories or its twentieth-century unfolding. New narratives that did not culminate in 1641, or in 1789, or that crossed 1933 or 1945, could now be imagined, new post- or transnational stories told, discursive formations rather than class societies scrutinized. None of this was bad or wrong; but it did make those left in the older paradigms seem a bit fusty, politically naïve, or just plain dull.

I saw the shift happen as a junior professor at Princeton (beginning in 1992), as many former nineteenth-century experts shifted to the twentieth century, and the field of early modern history blossomed. It would be wrong to say that these scholars no longer cared about the nineteenth century - for a long time after 1989, it remained crucial to reading lists and curricula. But especially with postmodernism's sidelining of Karl Marx in favor of, above all, Michel Foucault and Edward Said, it clearly had lost its salience and sex appeal. Both senior scholars and younger researchers wanted to do something new, to take advantage of the new insights and access to sources permitted by decolonization, poststructuralism, and the Cold War's end. That so many chose to take up later twentieth century history cannot be censured: every generation needs to seize the opportunities that come with its unique place in time, and to explore in detail the prehistories of its more immediate present. Despite being neither intriguingly close nor comfortably far away, the nineteenth century is still, to some extent, holding its own. A count of articles in the two major English-language journals for intellectual history, The Journal of the History of Ideas and Modern Intellectual History, for 2015 through the first two issues of 2018, reveals fifty essays on periods before 1800 (about half of which treat the eighteenth century), thirty-nine essays on the nineteenth century, and sixty-three on the twentieth century. ${ }^{4}$ This is not a dire situation, then, though I have the impression that senior scholars contributed many of the nineteenth-century pieces. Yet, like David Blackbourn, I am a bit concerned about

\footnotetext{
${ }^{3}$ See, e.g., Anthony Grafton, The Footnote: A Curious History (Cambridge, MA: Harvard University Press, 1997); David Sorkin, The Religious Enlightenment: Protestants, Jews, and Catholics from London to Vienna (Princeton, NJ: Princeton University Press, 2008); Steven Shapin, A Social History of Truth: Civility and Science in Seventeenth-Century England (Chicago, IL: University of Chicago Press, 1994); Caroline Winterer, American Enlightenments: Pursuing Happiness in the Age of Reason (New Haven, CT: Yale University Press, 2016); Jürgen Osterhammel, Die Entzauberung Asiens: Europa und die asiatischen Reiche im 18. Jahrhundert (Munich: C. H. Beck, 1998), now available in English translation: Unfabling the East: The Enlightenment's Encounter with Asia, trans. Robert Savage (Princeton, NJ: Princeton University Press, 2018); Emily J. Levine, Dreamland of Humanists: Warburg, Cassirer, Panofsky, and the Hamburg School (Chicago, IL: University of Chicago Press, 2015); Anne Harrington, Reenchanted Science: Holism in German Culture from Wilhelm II to Hitler (Princeton, NJ: Princeton University Press, 1996).

${ }^{4}$ Such a count is hardly statistically scientific, especially because it includes several "theme" issues that skewed the count in various ways.
} 
the extent to which recent $\mathrm{PhDs}$ have focused on very recent historical eras. ${ }^{5}$ It is challenging to historicize eras so close to our own, and hard to learn the research skills necessary to dive backward into earlier eras later in one's career. What is truly worrisome, however, is the way in which too many students and younger colleagues describe the eventful and complex nineteenth century - in which works of philosophical brilliance, immense scholarly significance, and artistic and literary beauty were also created—as "boring," "irrelevant," or, perhaps worst, politically incorrect. ${ }^{6}$ The spread of these descriptors may represent the most serious threat to the nineteenth century's vitality for future students as well as scholars.

How did the nineteenth century come to be boring? This is partly the product of wider pressures in our culture, and partly the result of technological modernization, new emphases placed on visual rather than print culture, the impatience with which we now treat slow travel, long courtships, lyric poets, amateur scientists, and intellectual invalids. How dull to wade through all of Anna Karenina when you can read a summary on Wikipedia or watch the movie(s)? We might not be surprised that our undergraduates say this, but I have also heard it from graduate students and some colleagues. ${ }^{7}$ When forced to trim my Western Civ course, I also tend to condense the nineteenth-century lectures rather than those on earlier or later periods. Why? Certainly, impatience plays a role; even I grow weary at the prospect of long discussions of Benjamin Disraeli and bourgeois culturelet's get on to the big wars, which is about all the students care about anyway. Thus do modern impatience and market forces, in the form of students' bottoms in chairs, gradually, unbidden, work their magic even on this hidebound believer in the wonderful world of Balzac, Cavour, and Dorian Gray.

But as long-winded and moderate as nineteenth-century politicians, scholars, and writers may have been-and unquestionably we could do a much better job in underlining the immoderate nature of nineteenth-century wars, class struggles, and familial conflicts - they would not be half so "boring" if they were thought to be relevant. ${ }^{8}$ And there, too, our culture and perhaps our own teaching have cut us off from this world, foreshortening our ancestries and, worse, making us forget that, as Steven Pinker has polemically pronounced, human societies have actually greatly improved their material conditions and perhaps even

\footnotetext{
${ }^{5}$ The resulting focus on the post-1945 era is illustrated in David Blackbourn, "Honey, I Shrunk German History," German Studies Association Newsletter 38, no. 2 (2013-2014): 44-53.

${ }^{6}$ The classic instances here come from critiques of nineteenth-century "orientalism" in art, literature, and scholarship. This was an important and necessary critique when it first began, but it became increasingly wearying in its predictability.

${ }^{7}$ I have not heard this from the participants in a summer 2018 Cambridge CRASSH (Centre for Research in the Arts, Social Sciences, and Humanities) seminar, which focused on the origins of the secular university in the nineteenth century; this highly diverse group of postdocs, many of whom focus on earlier or later periods, exhibited great interest in the nineteenth century's complex and ambivalent intellectual trajectories.

${ }^{8}$ For such material, see, e.g., Karen Hagemann, Revisiting Prussia's Wars Against Napoleon: History, Culture and Memory, trans. Pamela Selwyn (Cambridge: Cambridge University Press, 2015); V. G. Kiernan, Colonial Empires and Armies (Leicester: Leicester University Presss, 1982), and other recent work on the Indian Rebellion and other imperial wars; Simon Goldhill, A Very Queer Family Indeed: Sex, Religion, and the Bensons in Victorian Britain (Chicago, IL: University of Chicago Press, 2017); Todd Weir, Secularism and Religion in Nineteenth-Century Germany: The Rise of the Fourth Confession (Cambridge: Cambridge University Press, 2014); Walter Johnson, River of Dark Dreams: Slavery and Empire in the Cotton Kingdom (Cambridge, MA: Belknap Press, 2017).
} 
ethical states in the last 250 years. ${ }^{9}$ I do not worry about this greatly for those outside the intellectual elite; they have always been focused on making a living and enjoying the here and now. Inside academia, however, I believe our failure to emphasize and appreciate the relevance of the nineteenth century is strongly related to our recent infatuation with postcolonial and poststructuralist thinking. Both schools of thought emphasized what I will call the "glass-half-empty" view of modernization, in which the Enlightenment simply created hypocritical institutions and disciplines that enslaved us in discourses, "projects," and identities; both taught us to keep our critical distance from triumphalist narratives produced by post1945 politicians, scientists, and social activists. That, too, was useful and necessary; but I think we have reached the end of the usefulness of the work of Michel Foucault, Jacques Derrida, Edward Said, and Frederick Jameson, to name just a few.

In academia today, we have become so accustomed to being negative or even dismissive of "the modernization project" that we tend to forget the extent to which modernization also liberated us from evils such as legal inequality (including slavery and serfdom), religious discrimination, and subsistence agriculture - this is where Pinker has found room to criticize postmodernist pessimism, using, too, the statistical evidence we have too long disdained. In fact, Pinker, like the poststructuralists, gives insufficient agency and credit to the nineteenth century, treating "modernity" as the Enlightenment's inevitable end station once its wheels began to turn; his approach is simply the turning right-side up again the declensionist narrative epitomized by Foucault's Discipline and Punish, a narrative that almost makes one pine for the days of public torture. ${ }^{10}$ Both of these longue durée accounts obscure the partial successes and frequent reversals that our forerunners experienced on their way to achieving women's rights, antibiotics, and amazon.com — all of which fully deserve to be celebrated, but with the important proviso that none of them would exist today without the suffragettes, penny post, and experimental chemistry of the nineteenth century.

The foregoing paragraph hints clearly, too, at how the nineteenth century has become, among many historians, objectionable because politically incorrect. It is unquestionably so in our terms. But what happened to our commitment to understanding the past as "a foreign country"? We encourage students to understand seventeenth-century witches or alchemists in their own terms, but when it comes to nineteenth-century missionaries or "orientalists," we feel we must condemn rather than comprehend. To some extent, it was always so: Marx specialists of the 1970s and 1980s were eager to bash incompletely radical socialists or irredeemably religious peasants. But now that we do have distance, we should be able to do a better job of explicating popular science, protocapitalism, or post-Napoleonic monarchism. And to be clear: many historians have done a terrific job of this. ${ }^{11}$ It just does not seem to have taken strong hold in the imaginations of our students or in our teaching, textbooks, or casual

\footnotetext{
${ }^{9}$ Steven Pinker, Enlightenment Now: The Case for Reason, Science, Humanism, and Progress (New York: Viking Press, 2018); see also the critical reviews by David Bell in The Nation, April 2, 2018, and by David Wootton in The Times Literary Supplement, Feb. 14, 2018.

${ }^{10}$ See Michel Foucault, Discipline and Punish: The Birth of the Prison, trans. Alan Sheridan (New York: Vintage Books, 1995).

${ }^{11}$ See, e.g., James Secord, Victorian Sensation: The Extraordinary Publication, Reception, and Secret Authorship of the Vestiges of the Natural History of Creation (Chicago, IL: University of Chicago Press, 2001); Andreas Daum, Wissenschaftspopularisierung im 19. Jahrhundert (Munich: Oldenbourg Verlag, 1998); James Brophy, Capitalism, Politics, and Railroads in Prussia, 1830-1870 (Columbus: Ohio University Press, 1998); Abigail Green, Fatherlands: State-Building and Nationhood in Nineteenth-Century Germany (Cambridge: Cambridge University Press, 2004).
} 
discourse. Our convention is simply to denounce the nineteenth century as a fall into hardened racism, capitalism, or imperialism (if one is an early modernist), or to treat it as a trivial prelude to the manifold horrors of the more recent past. Constrained within a chronology that leaps from the Enlightenment to the Holocaust, its inhabitants have almost lost their own agency and individuality — and with that, their interest for us.

So, what is to be done? We need to combat with all our strength and imagination the lines of thought that label the nineteenth century as boring, irrelevant, and political incorrect. We need to do this, in part, by emphasizing that the nineteenth century gave birth to strange and wonderful creatures such as Arminius Vambéry (b. Hermann Wamberger), the penniless Hungarian Jew who taught himself myriad Asian languages and roamed across the Ottoman Empire pretending to be a dervish, as well as the Bohemian novelist Franziska ("Fanny") von Reventlow, who advocated free love rather than female suffrage and was welcomed into the most rarified and often bizarre German modernist circles. We need to draw students' attention to and celebrate the brilliance of the painting of J. M. W. Turner, Adolph Menzel, Edward Burne-Jones, and Arnold Böcklin; the architectural marvels of Karl Friedrich Schinkel, Otto Wagner, and Charles Barry; the decorative imaginations of Owen Jones, William Morris, and the Wiener Werkstätte. By the same token, we should expose the power of structural inequalities: that of Dutch colonial officials, for example, or of Belgian industrial employers and greedy Anglo-Irish and Spanish landowners, whose terrible exactions we too often elide. We need to emphasize contingencies, the long battles for constitutions, secret ballots, secular schooling, workers' rights, universal literacy, safe and affordable travel, and so much more, not all of which was accomplished in the nineteenth century (and much of which was impeded or destroyed by the catastrophes of the twentieth), but which many courageous and hardworking "bores" believed in so ardently. Boring people make history, too, in their everyday lives and works, and it is a risky business to teach our students that patient effort and dedication to making the world a better place are futile, that only heroes and martyrs are worthy of praise. ${ }^{12}$

For the sake of our students and our children, we need to make it safe to believe that flawed and moderate people can make a difference, and that incremental change does make peoples' lives better. It is not wise or helpful to stoke our students' appetites for apocalypse, or our culture's impatience with such nineteenth-century concepts as "science," "loyal opposition," and "the public good." Instead, we should look our embarrassment in the eye and not blink. We need to exhibit our passionate interest in the magnificent achievements, as well as the dismal failures, of these hundred years, and to explain to our impatient age why they should care about a more patient one. We need to show that we love what we study, and why we believe in its importance. Our ancestors, the Renaissance humanists, devoted themselves to ancient texts because they loved them and eagerly sought to find human truths in them. We need to do the same.

\footnotetext{
${ }^{12}$ We are fortunate that we can now access much more easily the ideas of "boring," or at least less exceptional, persons. Most of the parliamentary debates of major European countries, as well as many newspapers and nineteenth-century journals, can now be found online. The proceedings of the Old Bailey (England's chief criminal court), which offer fascinating insight into legal ideas and realities, have all been digitized (https://www.oldbaileyonline.org/); many museums-including the Victoria and Albert Museum (https://collections.vam.ac.uk/) — have also made large quantities of their collections accessible and thus a great resource for teaching.
} 


\title{
Gender and the Rewriting of Nineteenth-Century History
}

\author{
Karen Hagemann (University of North Carolina at Chapel Hill)
}

$\mathrm{F}$ OR European women's and gender history, the long nineteenth century is of crucial importance. In the period between 1750 and 1850, the so-called Sattelzeit of the transition to modernity, core ideas of the Western gender order were formed, which, in the following decades of the nineteenth century, increasingly spread through the state, economy, society, and culture. ${ }^{1}$ Because of its relevance for European women's and gender history, the nineteenth century was already one main focus of the early research of feminist historians, who also contributed in important ways to the development of the concept of gender. ${ }^{2}$ Most influential was Joan W. Scott, who suggested in her pathbreaking article, "Gender: A Useful Category of Historical Analysis," which appeared in 1986 in the American Historical Review, understanding gender as a subject and as an analytical category. She proposed conceptualizing gender as a constitutive element of social relationships based on perceived differences between the sexes, and as a primary way of constituting and signifying relationships of power, asymmetry, and hierarchy that create meaning in social and political life. Gender thus informs discourses and representations, laws and regulations, institutions and organizations, movements and practices, as well as individual and collective identities. ${ }^{3}$ Conceptualized in this way, gender is of pivotal importance for our understanding of the long nineteenth century in European history, because all central processes of transformation during that century - including industrialization, urbanization, and the democratization of politics - were, in one way or another, gendered. Accordingly, a systematic inclusion of both the subjects of women and gender, and the methodology of women's and gender history, is necessary for the study of the nineteenth century.

The majority of historians of the nineteenth century (whom I will henceforth refer to as "mainstream") nevertheless tend to ignore not only the importance of gender for the study of nineteenth-century European history, but also the research performed by women's and

\footnotetext{
${ }^{1}$ For more on this concept, see Reinhart Koselleck, "Einleitung," in Geschichtliche Grundbegriffe. Historisches Lexikon zur politisch-sozialen Sprache in Deutschland, vol. 1, ed. Otto Brunner, Werner Conze, and Reinhart Koselleck (Stuttgart: Ernst Klett, 1972), xiii-xxviii.

${ }^{2}$ For an overview of the early research, see Karen M. Offen, Ruth Roach Pierson, and Jane Rendall, eds., Writing Women's History: International Perspectives (Basingstoke: Macmillan, 1991). On the current state of European women's and gender history, see Ida Blom, Mineke Bosch, Anna Clark, Karen Hagemann, Laura E. Nym Mayhall, Karen Offen, and Mary Louise Roberts, "The Past and Present of European Women's and Gender History: A Transatlantic Conversation," Journal of Women's History 25, no. 4 (2013): 288-308; Anna Bellavitis and Nicole Edelman, eds., Genre, femmes, histoire en Europe: France, Italie, Espagne, Autriche (Nanterre: Presses Universitaires de Paris Ouest, 2014); Karen Hagemann and Jean H. Quataert, eds., Gendering Modern German History: Rewriting Historiography (Oxford: Berghahn Books, 2007).

3Joan W. Scott, “Gender: A Useful Category of Historical Analysis," American Historical Review (AHR) 98, no. 4 (1986): 1053-75; idem, Gender and the Politics of History (New York: Columbia University Press, 1999). For further discussion of the concept, see, e.g., the $A H R$ forum "Revisiting 'Gender: A Useful Category of Historical Analysis," AHR 113, no. 5 (2008): 1344-1430; Alexandra Shepard and Garthine Walker, eds., Gender and Change: Agency, Chronology and Periodisation (Oxford: Wiley-Blackwell, 2009); Laura Lee Downs, Writing Gender History (London: Bloomsbury, 2010).
} 
gender historians on that century. ${ }^{4}$ Feminist research on the development of the historical profession has identified, as one important reason for this tendency, the quest of mainstream historiography to produce a unifying "general" or "universal" history, which, since the professionalization of history during the nineteenth century, generated the white, male-elite, national master narratives of the historiography of Europe. Such master narratives served nation-state- and empire-building and legitimated the rule of the men in power. ${ }^{5}$ Feminist historians suggested instead an emphasis on the "non-unity of history" and a multiplicity of approaches. ${ }^{6}$

The research by women's and gender historians in the last four decades shows clearly that the roots of several current social, political, and cultural issues reach back to the long nineteenth century. Many of the gendered developments that characterized this age in European history laid the groundwork for today's challenges: industrialization and the rise of capitalism; demographic explosion (including large-scale migration); urbanization; the rise of the nation-state and its slow democratization, as well as the parallel growth of national chauvinism and racism; the beginning of the welfare state; and, last but not least, the assertion and globalization of colonialism and imperialism. ${ }^{7}$ These large-scale transformations went hand in hand, against a backdrop of continuities, with dramatic changes in the social and gender order, social relations, and culture, including everyday life. We can thus observe in the nineteenth century and its aftermath in the twentieth an often paradoxical intersection of change and continuity. ${ }^{8}$ One example is the continuing power of gender hierarchies, despite all the changes in law and norms, gendered representation, and gender relations, as the following cursory look at some of the pathbreaking research by women and gender historians on nineteenth-century, German-speaking Central Europe demonstrates.

Through their work, they critically deconstructed the basic ideas of the bourgeois gender order centered on the concept of separated spheres for men and women. This powerful construct emerged in the Enlightenment and has exerted a long-lasting influence over Western thought. Women's and gender historians have also challenged thinking about femininity, masculinity, and sexuality. Since the 1980s, they have emphasized that "gender" works only in interplay with other intersectional categories like "class," "race," "ethnicity," or "sexuality," and that the specific meanings and entanglements of these concepts depend on historical context and thus are constantly contested and changing. ${ }^{9}$ Furthermore, family

\footnotetext{
${ }^{4}$ For the scholarship on Central European history, see the critique by Isabel V. Hull, "Feminist and Gender History through the Literary Looking Glass: German Historiography in Postmodern Times," in the special issue "German Histories: Challenges in Theory, Practice, Technique," Central European History 22, no. 3-4 (1989): 279-300; Hagemann and Quataert, eds., Gendering Modern German History.

${ }^{5}$ See Bonnie Smith, The Gender of History: Men, Women, and Historical Practice (Cambridge, MA: Harvard University Press, 1998); Angelika Epple, Empfindsame Geschichtsschreibung. Eine Geschlechtergeschichte der Historiographie zwischen Aufklärung und Historismus (Cologne: Böhlau, 2003); Falko Schnicke, Die männliche Disziplin. Zur Vergeschlechtlichung der deutschen Geschichtswissenschaft 1780-1900 (Göttingen: Wallstein, 2015).

${ }^{6}$ See Karin Hausen, "Die Nicht-Einheit der Geschichte als historiographische Herausforderung. Zur historischen Relevanz und Anstößigkeit der Geschlechtergeschichte," in Geschlechtergeschichte und Allgemeine Geschichte. Herausforderungen und Perspektiven, ed. Hans Medick and Anne-Charlott Trepp (Göttingen: Wallstein, 1998), 17-55.

${ }^{7}$ For more on this argument, see the introduction to this forum.

${ }^{8}$ See David Armitage and Jo Guldi, The History Manifesto (Cambridge: Cambridge University Press, 2014).

${ }^{9}$ See, e.g., Karin Hausen, "Family and Role Division: The Polarisation of Sexual Stereotype in the Nineteenth Century-An Aspect of the Dissociation of Work and Family," in The German Family: Essays
} 
historians have explored the multiple realities of families occupying different social strata during the long nineteenth century, and thereby questioned the alleged "traditional dominance" of the nuclear, male-breadwinner family. ${ }^{10}$

Women's and gender historians have also made important contributions to the history of religion and religious milieus. They have studied the German-Jewish culture of the long nineteenth century by exploring the Jewish family and its gender relations, conversion, mixed marriages, gendered religious practices, and associational life. ${ }^{11}$ More generally, they examined early on the role of religion, Judaism as well as Christianity, in women's lives, as well as the room for maneuver that religion provided women to secure agency in private life and the public sphere. Pioneering studies explored women in German Catholicism and in the free religious communities of the 1840s and 1850 s, the religious dimensions of the mid-nineteenth-century women's movement, as well as Protestant and Catholic women's organizations in the late German Empire. ${ }^{12}$

Other works have demonstrated that the major economic and social transformations that shaped nineteenth-century Central Europe, like industrialization and urbanization, were likewise highly gendered. This research helped us to understand the development and power structures of the industrial workforce, and its gender-hierarchical division of labor. Early inquiries explored female factory work, the life course of French and German workers, and the everyday life and working conditions of urban domestic servants. ${ }^{13}$ Later studies analyzed the development of higher education for women, their entrance into professions such as law and medicine, and their attempts to create professional organizations. ${ }^{14}$

on the Social History of the Family in Nineteenth-and Twentieth-Century Germany, ed. Richard J. Evans and W. Robert Lee (London: Routledge, 1981), 51-83; Isabel V. Hull, Sexuality, State, and Civil Society in Germany, 1700-1815 (Ithaca, NY: Cornell University Press, 1996); Marion W. Gray, Productive Men, Reproductive Women: The Agrarian Household and the Emergence of Separate Spheres in the German Enlightenment (New York: Berghahn, 2000).

${ }^{10}$ See, e.g., Anne-Charlott Trepp, Sanfte Männlichkeit und selbständige Weiblichkeit. Frauen und Männer im Hamburger Bürgertum zwischen 1770 und 1840 (Göttingen: Vandenhoeck \& Ruprecht, 1996); Rebekka Habermas, Frauen und Männer des Bürgertums. Eine Familiengeschichte (1750-1850) (Göttingen: Vandenhoeck \& Ruprecht, 2000).

${ }^{11}$ Pathbreaking studies include Deborah Hertz, Jewish High Society in Old Regime (New Haven, CT: Yale University Press, 1988); Marion A. Kaplan, The Making of the Jewish Middle Class: Women, Family, and Identity in Imperial Germany (New York: Oxford University Press, 1991). For an overview of this research, see Benjamin Maria Baader, "Jews, Women, and Germans: Jewish and German Historiographies in a Transatlantic Perspective," in Hagemann and Quataert, Gendering, 169-89.

${ }^{12}$ Among the early studies were Catherine M. Prelinger, Charity, Challenge, and Change: Religious Dimensions of the Mid-Nineteenth-Century Women's Movement in Germany (New York: Greenwood Press, 1987); Sylvia Paletschek, Frauen und Dissens. Frauen im Deutschkatholizismus und in den freien Gemeinden 1841-1852 (Göttingen: Vandenhoeck \& Ruprecht, 1990); Dagmar Herzog, Intimacy and Exclusion: Religious Politics in Pre-Revolutionary Baden (Princeton, NJ: Princeton University Press, 1996). For an overview of this research, see Ann Taylor Allen, "Religion and Gender in Modern German History: A Historiographical Perspective," in Hagemann and Quataert, Gendering, 190-207.

${ }^{13}$ For an overview of this extensively researched field, see Kathleen Canning, "The Order of Terms: Class, Citizenship, and Welfare State in German Gender History," in Hagemann and Quataert, Gendering, 128-46.

${ }^{14}$ See, e.g., Brigitte Kerchner, Beruf und Geschlecht. Frauenberufsverbände in Deutschland 1848-1908 (Göttingen: Vandenhoeck \& Ruprecht, 1992); Harriet Pass Freidenreich, Female, Jewish, and Educated: The Lives of Central European University Women (Bloomington: Indiana University Press, 2002); Patricia M. Mazón, Gender and the Modern Research University: The Admission of Women to German Higher Education, 1865-1914 (Stanford, CA: Stanford University Press, 2003). 
Feminist scholarship also changed our understanding of the relationship between gender, the state, and politics in nineteenth-century Central Europe by extending the definitions of politics and citizenship and by demonstrating that the putatively private was highly political. Family, marriage, and reproduction were an important theme of political discourse, and they were subject to state regulation long before the twentieth century. Scholars have explored municipal poor relief and its gendered policies; the charity and welfare work of middleand upper-class women in the second half of the nineteenth century; the emerging middle-class women's movement and its maternalist approach to women's emancipation; the ideas of socialist feminism and the attempts at bringing working-class women into the labor movement; as well as the antifeminist backlash against the first women's movement. ${ }^{15}$

Women's and gender historians have, finally, contributed to our understanding of nation and empire by showing the ways in which both were, from the outset, informed by the intersectionality of gender, class, and race. They have demonstrated not only that national and imperial identities were created against internal and external others defined by hierarchical constructions of gender, class, and race, but also that collective memories played a crucial role in these constructions. These contested memories were gendered, too, as were national and imperial movements, associations, and cultures. ${ }^{16}$ Last but not least, these historians have broadened our comprehension of the interrelatedness of the military, war, and society by emphasizing the necessity of mobilizing both armed forces and civilian populations for war-long before the age of the world wars and the invention of the term home front during World War I. They have also demonstrated the importance of constructions of masculinity for military and imperial mobilization. ${ }^{17}$

Through their research, women's and gender historians who have worked on nineteenth-century Central Europe have contributed to and transformed our understanding of the era in multiple ways. They have often been at the forefront of historiographical innovation, including the linguistic, cultural, and postcolonial turns. Given this achievement, it is astonishing, on the one hand, how little of their work has entered mainstream scholarship and, on the other, that interest in the nineteenth century seems to have declined-also in women's and gender history in recent years, at least in the United States.

An analysis of the titles of research articles focusing on women' and gender history published in the American journal Central European History (CEH) illustrates this situation. During the 1980s, only 7 percent focused on themes in women's and gender history; in the 1990s and the first decade after the millennium, 12 percent; and, since 2010, not

\footnotetext{
${ }^{15}$ Important early studies include Jean H. Quataert, Reluctant Feminists in German Social Democracy, 1885-1917 (Princeton, NJ: Princeton University Press, 1979); Herrad-Ulrike Bussemer, Frauenemanzipation und Bildungsbürgertum. Sozialgeschichte der Frauenbewegung in der Reichsgründungszeit (Weinheim: Beltz, 1985); Ann Taylor Allen, Feminism and Motherhood in Germany, 1800-1914 (New Brunswick, NJ: Rutgers University Press, 1991); Ute Planert, Antifeminismus im Kaiserreich. Diskurs, Soziale Formation und Politische Mentalität (Göttingen: Vandenhoeck \& Ruprecht, 1998). For an overview of the research, see Belinda Davis, "The Personal is Political: Gender, Politics, and Political Activism in Modern German History," in Hagemann and Quataert, Gendering, 107-27.

${ }^{16}$ For overviews of these fields of research, see Angelika Schaser, "The Challenge of Gender: National Historiography, Nationalism, and National Identities," and Birthe Kundrus, "Blind Spots: Empire, Colonies, and Ethnic Identities in Modern German History," in Hagemann and Quataert, Gendering, 39-62, 86-106.

${ }^{17}$ For an overview of the research, see Karen Hagemann, "Military, War, and the Mainstreams: Gendering Modern German Military History,” in Hagemann and Quataert, Gendering, 63-85.
} 
more than 16 percent. The nineteenth century originally had a strong place in research published in CEH by women's and gender historians. ${ }^{18}$ In the 1980s, 42 percent of CEH articles on women's and gender history focused on the nineteenth century. That figure fell to 24 percent in the 1990s; in the first decade of the new millennium, it stood at 36 percent, but since 2010 it has declined to 14 percent. Since 2000, most articles on women's and gender history in the journal have focused on the twentieth century and, within that field, increasingly on the post-1945 period. A similar trend can be observed in the British journal German History, as well as at the annual meetings of the German Studies Association (GSA). ${ }^{19}$ Only six panels at the GSA's 2017 annual conference contained the word women in the title, three gender, and one masculinity. All ten of these panels-3 percent of the 306 panels in toto-focused on the twentieth century. Issues of women and gender were noticeably absent from most of the other panels, as was the nineteenth century.

In Germany, the situation is more complex. A look at the two German-language journals L'Homme. Europäische Zeitschrift für feministische Geschichtswissenschaft and Geschichte und Gesellschaft (GG) is illustrative in this respect. L'Homme has regularly published articles on the nineteenth century and earlier periods since its founding in 1990, and there has been no clear shift toward the twentieth century or the post- 1945 period..$^{20}$ By contrast, the temporal focus of the articles published in GG has taken a presentist turn. The number of articles on the nineteenth century has declined significantly since 2000 , and the focus is increasingly on post-1945 history. The decrease in the number of articles on women's and gender history in GG is even more marked. In the 1990s, twenty articles focused on this subject, i.e., 13 percent of all articles published in GG that decade; they were fairly evenly distributed among the time periods that the journal covers. During the period 2000 to 2009, by contrast, only five articles, i.e., 3 percent of all articles published in GG, dealt with women's and gender history, and, since 2010, only one article, i.e., less than 1 percent of all GG articles. All six of these articles focus on the twentieth century. ${ }^{21}$ The 2018 program of the 52nd German Historikertag, the biennial meeting of the Verband der Historiker und Historikerinnen Deutschlands, presents a similar picture. Only fourteen of all papers in the 102 sections (each with three to four presentations) examined subjects in women's and gender history; two of them focused on the nineteenth century, and most of the others covered the twentieth century. Only two sections were dedicated to issues of gender history, and only six of the other hundred sections included papers on women's and gender history. ${ }^{22}$

How can we explain this situation? Many of the general causes of the decline in importance of the nineteenth century in Central European history are discussed at length elsewhere in this forum. Instead of rehashing them here, I wish to point to some specific reasons for the field of women's and gender history. Clearly, younger women and gender historians are

\footnotetext{
${ }^{18}$ See Karen Hagemann and Donna Harsch, "Gendering Central European History: Changing Representations of Women and Gender in Comparison, 1968-2017," Central European History 51, no. 1 (2018): 114-27.

${ }^{19}$ Ibid.

${ }^{20}$ This is the finding of a content analysis of all regular articles published in L'Homme since 1990.

${ }^{21} \mathrm{This}$ is the finding of a content analysis of all regular articles published in Geschichte und Gesellschaft since 1990.

${ }^{22}$ See the program of the 52nd Historikertag (https://www.historikertag.de/Muenster2018/programmuebersicht.html).
} 
increasingly focusing on more recent historical periods because they want to explore a period they perceive as relevant and themes that seem to be fresh. But they often make this decision without knowing much about earlier scholarship on nineteenth-century women's and gender history, because they are rarely exposed to it in their undergraduate courses and graduate seminars. Graduate students interested in writing dissertations on topics in nineteenthcentury women's and gender history often say-but only in private conversations - that they received advice from more established scholars not to work in this "dual professional dead end": if they want to have a career, they need to choose fresh subjects and approaches that are in demand on the academic market.

The joint forces of generational change; the market-driven need for constant innovation in scholarship; the pressure of presentism; as well as the power of fashion in academic publishing, in the conference carousel, on the job market, and often in research funding — all are spuring the shift in attention away from the nineteenth century in women's and gender history, despite the century's importance for understanding the modern Western gender order. As a result, many important subjects of nineteenth-century women's and gender history remain to be explored. Examples from my current field of research, the history of the military, gender, and war, include the aftermath of war in European postwar societies and their gender order; gendered participation in the European revolutions of 1848/1849 and the ensuing civil wars; the effects of revolution and war upon politics, society, and culture in the 1850s and 1860s; gendered participation in, and experience of, the German and Italian wars of unification and the gendering of the memories of those wars. Other important subjects include the impact of imperialism, nationalism, and militarism on representations of gender; and, in particular for German history, gendered participation in the colonial and imperial project. The fact that these subjects have not yet been sufficiently explored makes it challenging, if not impossible, to understand the central place of the nineteenth century in the professionalization of the military, the modernization of warfare, or the molding of national and imperial politics - all three of which were highly gendered processes. In general, we lack comparative and transnational studies in nineteenth-century European women's and gender history that focus on specific topics. Instead, we mainly have general overviews for the purpose of teaching. ${ }^{23}$

The declining importance of the nineteenth century in the field of women's gender history is problematic for the reasons discussed earlier. If women's and gender historians, like their colleagues in other areas of European history, give in to the pressures described, they will undermine the relevance of their field. Instead, they need to demonstrate that

\footnotetext{
${ }^{23}$ One superb exception is Karen Offen, European Feminisms: A Political History, 1700-1950 (Stanford, CA: Stanford University Press, 2000). The overviews include Bonnie G. Smith, Changing Lives: Women in European History Since 1700 (Lexington, KY: D. C. Heath and Company, 1989); Geneviève Fraisse and Michelle Perrot, eds., A History of Women in the West, vol. 4: Emerging Feminism from Revolution to World War (Cambridge, MA: Belknap Press, 1993): Renate Bridenthal, Susan Mosher Stuard, and Merry E. Wiesner, eds., Becoming Visible: Women in European History (Boston: Houghton Mifflin, 1998); Marilyn J. Boxer and Jean H. Quataert, eds., Connecting Spheres: European Women in a Globalizing World, 1600 to the present, 2nd ed. (New York: Oxford University Press, 2000); Glenda Sluga and Barbara Caine, eds., Gendering European History, 1780-1920 (London: Leicester University Press, 2000); Lynn Abrams, The Making of Modern Woman: Europe 1789-1918 (London: Pearson, 2002); Gisela Bock, Women in European History, trans. Allison Brown (Oxford: Blackwell, 2002); Rachel G. Fuchs and Victoria Thomsen, Women in Nineteenth-Century Europe (Basingstoke: Palgrave MacMillan, 2005); Deborah Simonton, ed., The Routledge History of Women in Europe since 1700 (London: Routledge, 2007).
} 
there is no way that one can understand the present and the recent past by reducing gender history to the short twentieth century, much less the last fifty years. As gender historians, we have to insist on the importance of complex and entangled histories that include not only regional comparison and transnational and global perspectives, but also a longue-durée approach that allows for the study of continuity and change over one or more centuries. Both are still rare in women's and gender history of nineteenth-century Europe. 


\title{
Colonizing the Nineteenth Century: Implications of a Paradigm Shift
}

\author{
Sebastian Conrad (Free University of Berlin)
}

RE we losing the nineteenth century? Is it disappearing as an object of study? Does it
no longer serve as a reference point for genealogies of the present and for a broader
historical consciousness? At first sight, and speaking from the vantage point of German history, such an assessment seems hard to deny. It is corroborated by numbers and statistics; it is ascertained by the experts. ${ }^{1}$ Also, for many students-on a more impressionistic note- everything that happened before the twentieth century seems to fuse into a long, undefined antiquity.

To be sure, there is an element of trompe l'oeil in this, as historians of the twentieth century have recently nipped away at the preceding decades, incorporating the 1880s and 1890s into their interpretation of the twentieth century. Formerly the very model of a short century, extending from 1914 through 1989, the twentieth century has itself expanded at both ends. Influential readings have now posited the 1880s as the new Sattelzeit of high modernity and as the real origin of our present. The imposing image of the twentieth century, and the corresponding decline of the nineteenth, are thus partly the result of such expansionist moves. $^{2}$

But what matters is not simply the balance sheet between one decade and the next. In fact, the real significance of the vanishing of the 1900s lies elsewhere. What we are witnessing at this moment is not only, and not primarily, a shift of quantities. At stake, instead, is a much more profound transformation in our understanding of what counts as the prehistory of the present. The crucial issue is not the gradual waning of a period, but what I would call its colonization: the take-over and monopolization of the nineteenth century by colonial history.

Unlike many other fields, the history of pre-World War I colonialism is what the Germans call a Krisengewinnler: not only alive and kicking, but thriving and blossoming from a crisis. The classical and canonized fields may be languishing, but colonialism certainly is not. In Germany, the subject was close to nonexistent a mere two decades ago. ${ }^{3}$ Now it seems to be everybody's darling. There is hardly a history department in Germany that does not offer courses on Germany's colonial past. An avalanche of dissertations has turned German colonialism into a vibrant field. The German Historical Museum in Berlin, having largely avoided the topic for many years, put on a large (and critical) exhibition about German colonialism in 2016 that attracted huge crowds. In public debates, and in public memory, too, the colonial experience is highly visible and present.

\footnotetext{
${ }^{1}$ David Blackbourn, "Honey, I Shrunk German History," German Studies Association Newsletter 38, no. 2 (2013-2014): 44-53.

${ }^{2}$ Ulrich Herbert, Geschichte Deutschlands im 20. Jahrhundert (Munich: C. H. Beck, 2014); Jürgen Osterhammel, The Transformation of the World: A Global History of the Nineteenth Century, trans. Patrick Camiller (Princeton, NJ: Princeton University Press, 2014).

${ }^{3}$ Sebastian Conrad, "Doppelte Marginalisierung: Plädoyer für eine transnationale Perspektive auf die deutsche Geschichte," Geschichte \& Gesellschaft 28, no. 1 (2002): 145-69.
} 
The change in status, compared with twenty years ago, is indeed mind-boggling. In 1998, Sara Friedrichsmeyer, Sara Lennox, and Susanne Zantop still observed that the shadow of National Socialism hung heavy over German historians, and that the "focus on the Holocaust as the central and unavoidable fact of German history" was instrumental in occluding the country's colonial past. ${ }^{4}$ In fact, historians had to smuggle colonial themes in through the back door, feeling the need to prove the relevance of colonialism via its impact on the Third Reich. For example, racism in the colonies became a topic-but primarily as a prelude to the racial laws of the Nazis. The "Herero uprising" was renamed, first as a massacre and then as a genocide, but the importance of the event hinged on the purported continuity between the genocide of the Herero and the Holocaust. ${ }^{5}$ This was colonial history by invitation: colonial themes were admitted to mainstream historiography only if they could be read as contributions to the canon, to the standard narrative of German history. Today, the situation is almost the reverse: colonialism has emerged as the master trope. German expansion in the 1940s is now subsumed under the larger heading of imperialism, and the insights of colonial history are mobilized to make sense of what is increasingly called the "Nazi empire."6

To be sure, colonial history has not escaped the pull of the twentieth century either. The long aftermath of colonialism is increasingly catching the attention of historians: colonial revisionism during the Weimar Republic; 1968 in the context of decolonization; colonial memory, atonement, and compensation. But one can still safely say that, in the field of colonial history, the nineteenth century remains at the core-which is unsurprising, given that colonial rule largely came to an end in 1914 in the German case. But this is not solely a German story, for the nineteenth century remains at the heart of imperial histories elsewhere, not least in Britain.

What does this mean? What does it signify that large swaths of German history are "colonized," made relevant by linking them to a colonial problematic? The main take-away is that the nineteenth century no longer performs the functions that historians had ascribed to it for so long. The major narratives of postwar (West) Germany-the emergence of the nation-state, the birth of German democracy, the roots of modern social movements and revolution, the origins of National Socialism-had all pointed to the nineteenth century. But many of the central events in these stories - the Prussian reforms, the revolution of 1848, unification in 1871, Imperial Germany's social hierarchies - ring strangely hollow in today's world.

Instead, the nineteenth century is now mined for a genealogy of globalization. The dramatic increase in cross-border traffic, trade, capital investment, and mobility that characterized the 1990s (and gave rise to the discourse of "globalization" in the first place) has led

\footnotetext{
${ }^{4}$ Sara Friedrichsmeyer, Sara Lennox, and Susanne Zantop, eds., The Imperialist Imagination: German Colonialism and its Legacy (Ann Arbor: University of Michigan Press, 1998): 3-4.

${ }^{5}$ See, e.g., Jürgen Zimmerer, Von Windhoek nach Auschwitz: Beiträge zum Verhältnis von Kolonialismus und Holocaust (Münster: LIT, 2011). For a critical perspective on the continutity thesis, see Robert Gerwarth and Stephan Malinowski, "Hannah Arendt's Ghosts: Reflections on the Disputable Path from Windhoek to Auschwitz," Central European History 42, no. 2 (2009): 279-300; Matthew P. Fitzpatrick, "The PreHistory of the Holocaust? The Sonderweg and Historikerstreit Debates and the Abject Colonial Past," Central European History 41, no. 3 (2008): 477-503.

${ }^{6}$ Among many examples, see Mark Mazower, Hitler's Empire: Nazi Rule in Occupied Europe (London: Penguin, 2008); Shelley Baranowski, Nazi Empire: German Colonialism and Imperialism from Bismarck to Hitler (Cambridge: Cambridge University Press, 2010).
} 
historians to delve into the past and to search for the prehistory of the phenomenon. Globalization is now traced back to the 1880s, the 1780s, the 1600s, and even to the third millennium BCE. More characteristically, national histories have been retold, now placed-and resignified, even revalued - in their transnational and global contexts. ${ }^{7}$ There is something to Arjun Appadurai's intuition that this "rush to history," and the attempt to create long genealogies of the global, were an attempt to salvage national moorings in the midst of volatility and shifting grounds. ${ }^{8}$

Such perspectives jibed well with the larger transformation of public debate. In the wake of the Cold War and, in particular, after September 11, 2001, the broader public discussion also shifted from Germany's role in history to Germany's role in the world. This was a time when Germany's security began to be defended even "at the Hindukush," as the Social Democratic minister of defense Peter Struck famously put it in 2004. At the current conjuncture, the discussion about the Humboldt Forum - a central exhibition space in the center of the German capital, now revamped from being a Prussian castle into a space designed to showcase German worldliness - succinctly captures the mood of the times. How did all these objects end up in Berlin in the first place? Is the cosmopolitan refashioning of the new Germany made possible by and built upon colonial violence and outright looting?

In an age of frenzied conflicts over immigration and the nationalist-populist challenge, historical reference points have changed, too: from the Paulskirche and the Hall of Mirrors at the Palace of Versailles to the Berlin-Baghdad railway and the Omaheke desert. In German historiography, colonialism has emerged as the crucial site where these questions are discussed: the empire as the new lieu de mémoire. As before, the 1880s are seen as standing at the threshold of the present, but now they mark the initial stage of global modernity.

There can be no doubt that, in important ways, this new enthusiasm for things colonial comes at a cost and amounts to a narrowing of historical consciousness, as a whole range of themes and topics have passed to the historiographical dustbin. In similar ways, of course, earlier trends and conjunctures produced their own tunnel visions - of which, notably, the colonial past had been one of the casualties. Each new narrative succumbs to its own myopia. Instead of deploring the loss, it is therefore more productive to ask what kind of colonial history is in vogue today and what the implications of this specific approach might be. Colonial history is not simply colonial history, after all: it comes in a variety of forms. So what kind of vision of colonialism is it that the most recent scholarship is offering?

When colonial history experienced its first heyday in the 1970s, triggered by the violent struggles over decolonization (and, in the German case, by the critical reexamination of German history, spurred by the Fritz Fischer controversy), social history was the major

\footnotetext{
${ }^{7}$ Sebastian Conrad and Jürgen Osterhammel, eds., Das Kaiserreich transnational: Deutschland in der Welt 1871-1914 (Göttingen: Vandenhoeck \& Ruprecht, 2004); Georgii Kasianov and Philipp Ther, eds., $A$ Laboratory of Transnational History: Ukraine and Ukrainian Historiography since 1991 (Budapest: CEU Press, 2008); Vesna Drapac, Constructing Yugoslavia: A Transnational History (New York: Palgrave Macmillan, 2010); Niall Whelehan, ed., Transnational Perspectives on Modern Irish History (London: Routledge, 2014); Tyler Stovall, Transnational France: The Modern History of a Universal Nation (New York: Routledge, 2015); Patrick Boucheron, ed., Histoire mondiale de la France (Paris: Seuil, 2017); Andrea Giardina, ed., Storia Mondiale dell'Italia (Rome: Editori Laterza, 2017); Jorge Luengo and Pol Dalmau, "Writing Spanish History in the Global Age: Connections and Entanglements in the Nineteenth Century," Journal of Global History 13, no. 3 (2018): 425-55.

${ }^{8}$ Arjun Appadurai, "Globalization and the Rush to History," paper presented at Sawyer Seminar, Columbia University, New York, Oct. 28, 1999.
} 
paradigm. The focus was on colonial suppression, colonial wars, and exploitation-but, even more important, it was on Germany itself: colonial expansion in the service of class interests, and social imperialism as a variant of the German Sonderweg. At the turn of the millennium, the rise of postcolonial studies triggered a second explosion of scholarship, this time in a cultural history vein: discourse and representation, colonial knowledge, and memory, but also a renewed interest in subaltern agency. ${ }^{9}$

In many ways, recent work has not abandoned these trends, as some of the earlier debates remain on the agenda of a new generation of historians. Then as now, the Herero wars of 1904-1908 and the system of concentration camps that was part of colonial warfare are crucial sites, both of archival exploration and political mobilization. The nature of the colonial state-weak or strong? - and the role of local actors remain among the most productive fields of inquiry. We should also not forget that cultural history continues to be highly influential- even if much of the recent output, given the long periods of gestation, is partly the after-image of an earlier fascination. ${ }^{10}$

The most conspicuous change in the field, however, is its transnational and global turn. Until very recently, colonial empires were studied essentially in isolation, as national affairs. The postcolonial approach helped bring together metropole and colony, and enabled historians to look at repercussions and interferences, but the optic nevertheless remained national and within individual empires: the Belgian, the French, the Japanese. Only in the past few years have scholars seriously taken up the challenge of recreating a fuller, more comprehensive picture of the transborder interactions and global structures that shaped the colonial era.

Such a perspective has opened up a host of fascinating and innovative avenues of research. Some of the most promising approaches have looked at historical actors and at social practices that were not confined by national or imperial borders. For example, historians have looked at the protagonists of the colonial project: both state officials and "private" actors, such as merchants, traders, and missionaries. They have shown that the age of empire was not compartmentalized nationally; many of the underlying assumptions and agendas were shared, and inter-imperial contact was a constant reality, whether as collaboration, negotiation, or struggle. ${ }^{11}$ The same is true, on the other side of the colonial divide, for resistance movements and anticolonial activists. As recent scholarship has pointed out, transregional coalitions of antiimperial nationalists were not a product of the Bandung era, but had formed much earlier. Ironically, not only imperial centers such as London, Paris, and Istanbul but also New York, Geneva, Shanghai, and Berlin served as important nodal points where protagonists from different colonized countries interacted, and where surveillance was strict but not

\footnotetext{
${ }^{9}$ For a brief summary of this earlier scholarship, see Sebastian Conrad, "German Colonial History: New Trends and Perspectives," Mondo Contemporaneo. Rivista di Storia 3, no. 3 (2007): 105-15.

${ }^{10}$ For good summaries of recent scholarship on German colonialism, see Minu Haschemi Yekani and Ulrike Schaper, "Pictures, Postcards, Points of Contact: New Approaches to Cultural Histories of German Colonialism," German History 35, no. 4 (2017): 602-23; Matthew P. Fitzpatrick, "Colonialism, Postcolonialism, and Decolonization," Central European History 51, no. 1 (2018): 83-89.

${ }^{11}$ Jonas Kreienbaum and Christoph Kamissek, eds., "An Imperial Cloud," special issue of Journal of Modern European History, vol. 14, no. 2 (2016); Ulrike Lindner, Koloniale Begegnungen: Deutschland und Großbritannien als Imperialmächte in Afrika 1880-1914 (Frankfurt/Main: Campus, 2011). See also Marilyn Lake and Henry Reynolds, Drawing the Global Color Line: White Men's Countries and the International Challenge of Racial Equality (Cambridge: Cambridge University Press, 2008).
} 
as harsh as at home. ${ }^{12}$ In turn, these multifarious interactions were made possible, and deeply shaped, by a set of structural constraints, of which capitalism and imperialism were only the most conspicuous. ${ }^{13}$

Much of this recent scholarship is fresh and exciting, and it opens up vistas on connectivity that an earlier obsession with national narratives had largely foreclosed. But, as always, the new focus has engendered its own biases and exclusions. One of them is the way in which new global histories have emphasized the almost transhistorical nature of empire. As a result, empires appear as the quasi-natural state of affairs, and one of the historian's tasks is to explain its longevity. "Empire," writes John Darwin, "has been the default mode of political organization throughout most of history. Imperial power has usually been the rule of the road." 14 Such a perspective does not, in principle, stand in opposition to a critical, postcolonial view that sees empire as "a non-consensual regime of exploitation, where the application of force to bodies to extract information, to spread terror, to break the will to resist, is fundamental." 15 But the emphasis and the major concerns of the two perspectives are certainly not identical.

In such a post-postcolonial framework, concern with the casualties of foreign rule and exploitation may easily give way to more functionalist considerations: empires as managers of diversity, as experiments with layered and gradated sovereignty, as stepping stones in the history of globalization. Again, there is no necessary connection between global perspectives and depoliticized narratives. Quite the contrary: most historians of colonialism are driven to their subjects by their criticism of the manifold and sometimes hidden forms that empire takes in the present. But it should give us pause that strongly revisionist positions, which see empire as a healthy ingredient of "Anglobalization" and that call for a reevaluation (and even continuation) of colonialism, have surfaced at the same moment. ${ }^{16}$ They are not of the same stock, but they are the product of the same historical conjuncture.

\footnotetext{
${ }^{12}$ Michael Goebel, Anti-Imperial Metropolis: Interwar Paris and the Seeds of Third World Nationalism (Cambridge: Cambridge University Press, 2015). See also Jennifer Anne Boittin, Colonial Metropolis: The Urban Grounds of Anti-Imperialism and Feminism in Interwar Paris (Lincoln: University of Nebraska Press, 2010); Noor-Aiman I. Khan, Egyptian-Indian Nationalist Collaboration and the British Empire (New York: Palgrave Macmillan, 2011); Nathanael Kuck, “Anticolonialism in a Post-Imperial Environment: The Case of Berlin, 1914-1933," Journal of Contemporary History 49, no. 1 (2014): 134-59; Marc Matera, Black London: The Imperial Metropolis and Decolonization in the Twentieth Century (Berkeley: University of California Press, 2015); Daniel Brückenhaus, Policing Transnational Protest: Liberal Imperialism and the Surveillance of Anticolonialists in Europe, 1905-1945 (New York: Oxford University Press, 2017).

${ }^{13}$ Sebastian Conrad, "Rethinking German Colonialism in a Global Age," Journal of Imperial and Commonwealth History 41, no. 4 (2013): 543-66. See also Minu Haschemi Yekani, Koloniale Arbeit: Rassismus, Migration und Herrschaft in Tansania (1885-1914) (Frankfurt/Main: Campus, 2019).

${ }^{14}$ John Darwin, After Tamerlane: The Global History of Empire (London: Penguin, 2007), 23.

${ }^{15}$ Richard Drayton, "Where Does the World Historian Write From? Objectivity, Moral Conscience and the Past and Present of Imperialism," Journal of Contemporary History 46, no. 3 (2011): 671-85.

${ }^{16}$ Niall Ferguson, Empire: How Britain Made the Modern World (London: Penguin, 2004), xxii; Bruce Gilley, "The Case for Colonialism," Third World Quarterly (published online, 2017) [the article has since been removed from the journal].
} 


\section{Comments}

\section{Birgit Aschmann (Humboldt University Berlin)}

I the nineteenth century "vanishing" or even "dying"? This was the key question that the historians participating in this forum were supposed to answer. The result is much less worrying than the editors' introduction suggests. There are no reports of death throes; instead, our colleagues are almost optimistic. Everyone agrees on the century's relevance, which is hardly surprising when historians weigh in on an era that is close to their own hearts. Their position is supported by various statistics, which are not nearly as bad as had apparently been feared. Even if the share of published articles or monographs counted in leading academic journals declined noticeably in relation to publications on the twentieth century, the contributors praise the high quality of publications on the nineteenth century. A crisis this certainly is not.

Alexander M. Martin diagnoses an "encouraging picture" with regard to Russian history; Lloyd S. Kramer posits that the nineteenth century will remain "an essential century" for French history, and Alex Chase-Levenson finds that it is "of sustained relevance" for British history. It seems that the most dramatic caesura occurred in the historiography of Germany. As early as 2006, Paul Nolte noticed a "leave-taking from the nineteenth century." "That impression was confirmed by David Blackbourn's 2013 assessment of the situation in (primarily) the American historical profession. ${ }^{2}$ Yet, Blackbourn's contribution to this forum is less a description of a crisis than a highlighting of optimistic prospects for the future. Perhaps the low point of dwindling interest has already passed. But what caused this (temporary) lack of interest in the nineteenth century in the first place?

General methodological and national developments clearly play a significant role in shaping historiographic trends. First, all the contributors point to the simple yet important fact that time goes on and that the temporal distance between the nineteenth century and the present is therefore growing. If the focus of historiography always depends on the subject's relevance for the researcher and the central questions of his or her own time, it is significant if neither individual nor collective biographical experience still has anything to do with the nineteenth century. Second, we need to consider pragmatic aspects of research, such as the sudden opening of the archives of the German Democratic Republic and the Soviet Union after 1989. Third, the relevance of nation-state master narratives plays a role. The nineteenth century is prominent in France, not least because of the revolutions that are so important for its national self-image. In Britain, the nineteenth century remains important as the era of its global expansion. In the historiography of the Federal Republic of Germany, by contrast, the significance of the nineteenth century rested on its potential for helping to explain National Socialism. As the Sonderweg thesis gradually collapsed, the focus of historical research on German fascism shifted from the nineteenth to the twentieth century — and the nineteenth century fell out of sight. It was not forgotten; rather, it seemed

\footnotetext{
${ }^{1}$ Paul Nolte, "Abschied vom 19. Jahrhundert oder Auf der Suche nach einer anderen Moderne," Geschichte und Gesellschaft Sonderheft 22 (2006): 103-32.

${ }^{2}$ David Blackbourn, "Honey, I Shrunk German History," German Studies Association Newsletter 38, no. 2 (2013-2014): 44-53.
} 
"played out" because the various Sonderforschungsbereiche (collaborative research projects) on the nineteenth century had already filled shelf after shelf with doctoral dissertations and Habilitationsschriften. Given the flow of publications from these and other collaborative projects between the 1970s and the 1990s, it is not surprising that the number of books and articles on the nineteenth century decreased in the following decades.

Methodological shifts within the discipline contributed further to the decline in interest in the nineteenth century. Whereas social history continued to highlight fundamental processes that shaped the structures of the nineteenth and twentieth centuries - such as nationalization, industrialization, and urbanization — cultural history began in the 1980s to focus on shorter time periods. Instead of analyzing structures, cultural history underscored the significance of contingency in history. Moreover, poststructuralism contributed to the deconstruction of all master narratives and, with them, theories of modernization, thereby shattering the foundations upon which research on the nineteenth century had once securely rested. That the nineteenth century nevertheless did not disappear from view was a result, as a number of the contributors to this forum note, of shifts in the topics of research.

In the same year that Paul Nolte diagnosed the "leave-taking from the nineteenth century," a German translation of Christopher Bayly's The Birth of the Modern World was published. ${ }^{3}$ Three years later, Jürgen Osterhammel published his opus magnum, Die Verwandlung der Welt. Eine Geschichte des 19. Jahrhunderts. ${ }^{4}$ Both works are ambitious global histories and, at the same time, impressive reevaluations of the nineteenth century. The publication of these two books coincided with the triumph of a mode of historical writing that left the "national" behind in favor of the transnational, the imperial, the colonial, and the global. Research on the nineteenth-century histories of the Habsburg and Russian empires profited from the "imperial turn," as Pieter M. Judson and Alexander Martin note in this forum, and that explains why neither of them sees a historiographic crisis for the nineteenth century. With their multinational make-ups, both empires were predestined for transnational research and comparison.

European historiography on the nineteenth century has benefitted from the "colonial turn." A large part of research on the century has dealt, in recent years, with colonial history. In view of the dominance of colonial history, Sebastian Conrad even speaks of a "colonization of the nineteenth century." The history of nineteenth-century Europe stood to benefit from this trend because much of the research on colonial history increased our knowledge about the actors and societies of the colonizing countries. Even a colonial history that highlights the agency of those in colonized regions, or the transnational or transcontinental connections that developed as a result of colonization, is nonetheless a history that deepens our knowledge about nineteenth-century European history. After all, that century played a key role in colonial and global history-certainly in German colonial history.

It remains to be seen when and to what extent interest global history will wane in the years ahead, and whether increasing criticism of globalization will have repercussions for the global

\footnotetext{
${ }^{3}$ Christopher Bayly, Die Geburt der modernen Welt. Eine Globalgeschichte 1780-1914, trans. Thomas Bertram and Martin Klaus (Frankfurt/Main: Campus, 2006); orig. published as The Birth of the Modern World, 1780-1914: Global Connections and Comparisons (Oxford: Blackwell-Wiley, 2004).

${ }^{4}$ Jürgen Osterhammel, Die Verwandlung der Welt. Eine Geschichte des 19. Jahrhunderts (Munich: C. H. Beck, 2009); published in English translation as The Transformation of the World: A Global History of the Nineteenth Century, trans. Patrick Camiller (Princeton, NJ: Princeton University Press, 2014).
} 
history boom. Global historians point out as a precaution that global history is not identical to the history of globalization. ${ }^{5}$ Given the speed with which methodical shifts and the prioritization of new subject areas have taken place in the past twenty years, it is not likely that global history will remain unaffected by changing research trends. As of yet, it is impossible, of course, to tell what course new trends will take. New developments now under discussion, such as the material turn, are not covered in this forum. It would be interesting to consider the extent to which that concept, which has been taken up mainly in early modern history, might be developed for application to the nineteenth century.

Military history and the history of war have managed skillfully to integrate developments in fields ranging from social history to cultural, global, and colonial history—as, for example, comparative studies on bellicism demonstrate. Nineteenth-century military history "remains ... vibrant," according to Roger Chickering. Meanwhile women's and gender history, which have played a decisive part in pushing the "cultural turn" on both sides of the Atlantic since the 1980s, seem to be among the losers of this thematic shift, as Karen Hagemann notes in her contribution. Although the gender concepts established in the nineteenth century remain influential today, relatively few historians are currently interested in this topic.

Likewise, intellectual history has not benefited from the global and colonial turns. Suzanne Marchand observes that the intellectual history of the nineteenth century is simply "boring" to students. In our "age of impatience," she reports, long-winded letters or rambling parliamentary debates can no longer be used as sources in teaching. The critical theories advanced by social reformers of the period have lost their traction, and the great literary figures of the nineteenth century stand accused of being privileged, old, politically incorrect, white middle-class men-as Lloyd S. Kramer notes as well. Interest in the bürgerliche movements and achievements of the nineteenth century has obviously flagged. Neither the mid-century revolution nor the path towards parlamentarization rouses much enthusiasm today. One reason for this is that scholarship currently focuses on the years at either end of the nineteenth century. Those decades, in any event, demonstrate that the nineteenth century is anything but boring.

Not only are there historians of the nineteenth century with an interest in the twentieth century, but there are also scholars of the twentieth century who have discovered the $1880 \mathrm{~s}$ and 1890s for themselves. When this period is interpreted as the prelude to the twentieth century, there is suddenly talk of the "short nineteenth century" - not least because scholars of the early modern period have laid claim to the early years of the nineteenth century for their narratives. This raises the question of the duration, unity, and internal divisions of the nineteenth century. That is a tricky question because we obviously cannot simply go by the calendar in designating historical epochs.

It is difficult to pinpoint the beginning and the end of the nineteenth century. All the contributions to this forum assume periods of transition at the century's start and close, rather than specifying particular years. There is, however, no consensus on how long these transitions lasted. Many of the contributors employ Reinhart Koselleck's concept of the Sattelzeit, using it, however, primarily to designate a period of fundamental social and

\footnotetext{
${ }^{5}$ See Andreas Eckert, "Die Globalgeschichte wirft den Anker aus," Frankfurter Allgemeine Zeitung, May 16, 2017. "As national consciousness has grown stronger, global history has come under criticism," he writes at the outset of his article. "Has it indulged too heavily in the global?"
} 
political transformation rather than of change in the way certain basic concepts were understood. In this context, it matters greatly whether the Sattelzeit is understood to last until 1830 or 1850. If we opt for the latter and then take the 1880s as the start of the transition to the twentieth century, there is not much left of the "actual" nineteenth century. It is precisely these years that have fallen into a sort of historiographic vacuum. Even the Sattelzeit must be reassessed, David Blackbourn, James M. Brophy, and others stress. Yet, that is the era of the French Revolution, Napoleon, and the anti-Napoleonic wars-all topics of a steady stream of new publications. Writing of the years that follow, Judson emphasizes that this is, in fact, "a period about which we know shocking little" for the Habsburg realm. There is therefore an urgent need to approach the 1830s to 1880s from a fresh perspective. At present, the scholarship, concepts, and terminology for analyzing this period mostly date from the 1960s, when Werner Conze located the origins of the modern age in the Vormärz. ${ }^{6}$ It is particularly with regard to this period that the nineteenth century needs to be analyzed, in local, regional, transnational, and global contexts, as a transitional epoch with hybrid forms of diversity and homogeneity, universal phenomena and national particularism, mechanisms of inclusion and exclusion, as well as an alliance or competition between the secular and religious spheres.

Despite the broad range of topics covered in this forum, some gaps remain. The topics one misses inevitably relate to one's own interests, but it is nevertheless important to ask whether the situation is any different in the historiography of northern or southern Europe. For example, when it is suggested that liberal democracy might possibly be a northwest European Sonderweg, a glance at Spain's constitution of 1812 suffices to cast doubt on that hypothesis. Spain would, in fact, have provided an additional interesting case study. Scholarship on the nineteenth century, after long neglect during the Franco era, got off to a late start in Spain, but it is now well developed there institutionally. Excellent research networks have been established, particularly on the transnational level. Studying the Spanish case could contribute significantly to our understanding of the role of war and violence in the nineteenth century, as well as of the relationship between church and state. ${ }^{7}$

Religion is another topic that might have received more attention in this forum, though it is, of course, touched upon in Simone Lässig's contribution on Jewish history. In noting that religion has the capacity to strengthen social resilience in times of transition, Lässig points to new avenues for research. The study of religion is not relevant solely for church history or cultural history: it is also of interest to anyone studying the stability of states. Most of the other contributions touch upon the topic of religion, which suggests its general importance in the nineteenth century. Moreover, there has been considerable research, much of it innovative, on this topic in recent years. It would thus have been easy to justify a contribution to the forum focusing specifically on the history of religion.

\footnotetext{
${ }^{6}$ Werner Conze, ed., Staat und Gesellschaft im deutschen Vormärz 1815-1848 (Stuttgart: Ernst Klett, 1962). For one of the more recent studies, see Adam Zamoyski, Phantom Terror: The Threat of Revolution and the Repression of Liberty 1789-1848 (London: William Collins, 2014).

${ }^{7}$ See, e.g., Gregorio Alonso, La nación en capilla. Ciudadanía católica y cuestión religiosa en España (1793-1874) (Granada: Editorial Comares, 2014); Charles Esdaile, Peninsular Eyewitnesses: The Experience of War in Spain and Portugal 1808-1813 (Barnsley: Pen and Sword, 2008); Julio Aróstegui, Jordi Canal, and Eduardo González Calleja, El carlismo y las guerras carlistas. Hechos, hombres e ideas (Madrid: La Esfera de los Libros, 2003).
} 
The same holds for the history of emotions. Brophy, for example, suggests that we look at the "longest hatred" as a structural element explaining the Holocaust, and Kramer points out the relevance of "anger or fear" in response to the transformations that were underway during the Sattelzeit. Fear played a key role during the transitional phases at the beginning and end of the nineteenth century, and it deserves closer study. That emotions have a history in the nineteenth century is documented in handbooks, such as the second volume of the Histoire des Émotions, which covers the period from the Enlightenment to $1880 .{ }^{8}$ At the same time, the interplay of emotions with culture and politics is undeniable. Richard J. Evans has described the nineteenth century as the "Age of Emotion," and he dedicates one of the eight chapters of his impressive survey of the century to that subject. ${ }^{9}$ It is significant that religion, gender issues, and assassination attempts all fall under this heading. In fact, the history of assassination attempts as a particularity of the nineteenth-century history of violence-which mainstream military history has yet to consider-is the subject of several recent and forthcoming studies. ${ }^{10}$

Having surveyed new approaches and trends, I want to comment briefly on the question of new perspectives on the nineteenth century. First, following the poststructuralist deconstruction of master narratives, the desire for broader lines of interpretation is suddenly growing again. The pendulum seems to be swinging back from micro- to mega-history. More attention to the longue durée does not necessarily have to lead to "deep history" spanning several millennia. ${ }^{11}$ There nevertheless seems to be a trend toward historical studies that span several centuries. But the longer the period under consideration, the weaker the source material's veto power over the scholar's interpretive omnipotence. Studies that range over multiple centuries consequently tend to draw bold conclusions. The centuries-long sweep of Niall Ferguson's book on British colonial history largely disregards the dark side of the subject. Much the same applies to Steven Pinker's Enlightenment Now, which Suzanne Marchand cites. Viewed from a bird's eye perspective, the history of the past 250 years becomes an indisputable success story. Clearly, theories of modernization are making a comeback.

To counter all too simple interpretations, we need historical studies of the nineteenth century that leave the reader with an ambivalent impression of the century and that make clear the impossibility of reducing the century to the lowest common denominator. Serious engagement with the nineteenth century will yield paradoxical, contradictory findings, and it is precisely such findings that point to three dimensions of the century that historians find so exciting. First, we can emphasize the exotic. Many aspects of the nineteenth century - its verbose culture of letter writing, for example, or the religious ecstasy of stigmatized women - appear absolutely alien to us today and thus remind us that writing history is indeed a journey to a foreign country. Second, in analyzing the nineteenth century, we come across phenomena that had their origins there but that still have consequences for the present.

\footnotetext{
${ }^{8}$ Alain Corbin, ed., Histoire des Émotions, vol. 2: Des Lumières à la fin du XIXe siècle (Paris: Seuil, 2016).

${ }^{9}$ Richard J. Evans, The Pursuit of Power: Europe 1815-1914 (London: Allen Lane, 2016), 444-536.

${ }^{10}$ See, e.g., Carola Dietze, Die Erfindung des Terrorismus in Europa, Russland und den USA 1858-1866 (Hamburg: Hamburger Edition, 2016); Heinz-Gerhard Haupt and Daniel Schönpflug are each working on books dealing with terrorism in the nineteenth century.

${ }^{11}$ This desire is expressed in Jo Guldi and David Armitage, The History Manifesto (Cambridge: Cambridge University Press, 2014); for a justifiably critical appreciation, see Stefan Jordan's review (https://www.hsozkult.de/publicationreview/id/rezbuecher-24896).
} 
These include gender concepts, as well as democracy-with its successes and crises. These lines of development invite us to consider the nineteenth and twentieth centuries together as the epoch of modernity. Third - and this is one of the most disturbing, yet also most stimulating phenomena-we see striking parallels. ${ }^{12}$ It is not only a case of similarities between the periods of radical change at the beginning and the end of the nineteenth century, but also of similarities between those two periods and our present situation. The political, social, and cultural (read: digital) transformations of recent decades suggest that we are in the midst of a third Sattelzeit that bears a striking resemblance to its predecessors. Quite suddenly and unexpectedly, the nineteenth century has become very relevant.

Almost all the contributors to this forum thus highlight "striking parallels" between our twenty-first century and phases of the nineteenth. Issues such as migration, populism, capitalism, and nationalism are far from new. Studying the nineteenth century affords us the opportunity to explore strategies for responding to crises arising from wide-reaching fundamental change, for instance, or the ways in which times of uncertainty can open the way for authoritarian regimes. To those examining the current crisis of transformative change, the nineteenth century no longer seems so foreign. "In our age of anxiety," Martin writes, "it feels more present than ever." Brophy confirms that "time has indeed moved on, but many subjects draw the nineteenth century closer." It is unclear, as yet, what it means for our thinking about the past when history seems to be moving forward and backwards at the same time, when fundamental crises seem to occur at intervals of about a hundred years. The contributions to this forum do make one thing clear, though: the nineteenth century is increasingly relevant for the present. For the time being, that in itself should guarantee that the nineteenth century is anything but a "vanishing century."

Translated by Insa Kummer

\footnotetext{
${ }^{12} \mathrm{On}$ this phenomenon, see the introduction and essay in Birgit Aschmann, ed., Das 19. Jahrhundert: Durchbruch der Moderne? (Frankfurt/Main: Campus, 2019).
} 


\section{Jürgen Osterhammel (University of Konstanz)}

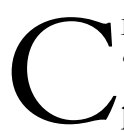

ENTURIES rarely get lost forever, though they may pass out of fashion. Max Weber's "light of the great cultural problems" moves on to illuminate other ages. ${ }^{1}$ After periods of intense scholarly endeavor, a period is exhausted like overexploited soil. Few stones have been left unturned. The marginal utility of the latest book or article added to a bibliography declines. Laurels beckon elsewhere. Enthusiastic and ambitious young scholars flock to the frontiers of research, as they should.

Yet, there is no reason to worry too much. When a century's reputation hits rock bottom, along comes a gifted historian to the rescue. Who cared for the seemingly dismal fourteenth century - after the glory of great monarchs, great architects, and great thinkers, but with pestilence and war everywhere-before Johan Huizinga revealed its dark wonders in 1919? ${ }^{2}$ Who would have thought that the prerevolutionary eighteenth century - a dry-as-dust "age of reason"-could ever recover from the aspersions of Romantic historians? One might respond to such an attitude of relaxed contemplation by quoting John Maynard Keynes: "In the long run we are all dead." To be sure, in an "age of impatience" (Suzanne Marchand), we have no time to oscillate leisurely with the long cycles of waxing and waning interest. And bending those cycles to one's will—through splashy revisionism or, more precisely, asserting with good reason the opposite of what is believed to be true-is a hazardous strategy that a conscientious professor should not recommend to $\mathrm{PhD}$ candidates. It might lead to stardom, but it could also end in a crash landing. A well-tempered fatalism, or market conformity, seem to be the safer bet.

Tenured professors, especially those who do not lead from the front as managers of a new field, can better afford the luxury of countercyclical behavior. Because I am not an "insider," not a proper dix-neuvièmiste, I am in a semi-detached position from which to contribute this comment on the preceding contributions to this forum. My research monographs have dealt with topics from the twentieth and eighteenth centuries, and the Enlightenment remains my principal comfort zone. When, for reasons difficult to explain, I decided to take a closer look at the nineteenth century and write an interpretative essay about it, friends and colleagues advised against such suicidal recklessness. ${ }^{3}$ There did not seem to be an alternative to trotting out the same "well-worn" stories (James Brophy) or "teleological master narratives" (David Blackbourn) - thus a recipe for ruining whatever modest reputation one may have had.

Yet, scavenging through the "historiographical dustbin" and reexamining topics that, to many nowadays "ring hollow" (Sebastian Conrad), had its own morbid pleasures. To turn the argument upside down: the incredible richness of international research on the nineteenth century - by no means on Europe and North America alone-makes gliding like Minerva's owl over the dusky landscapes of scholarly achievement such a rewarding

\footnotetext{
${ }^{1}$ Max Weber, "Das Licht der großen Kulturprobleme ist weiter gezogen," in Gesammelte Aufsätze zur Wissenschaftslehre, 3rd ed., ed. Johannes Winckelmann (Tübingen: Mohr-Siebeck, 1968), 214.

${ }^{2}$ Johan Huizinga, The Autumn of the Middle Ages, trans. Rodney J. Payton and Ulrich Mammitzsch (Chicago, IL: University of Chicago Press, 1996); the original Dutch edition appeared in 1919.

${ }^{3}$ Jürgen Osterhammel, The Transformation of the World: A Global History of the Nineteenth Century, trans. Patrick Camiller (Princeton, NJ: Princeton University Press, 2014). For an introduction intended for a general public, which discusses the nineteenth century at three distinct levels (Germany-Europeworld), see also idem, Das 19. Jahrhundert (Bonn: Bundeszentrale für politische Bildung, 2012).
} 
experience. A feeling of immense admiration and gratitude for what thousands of scholars around the world have accomplished should outweigh any anxiety that a century, admired by some and reviled by others, may be slipping from our grasp. The view from the rear reveals other things — and perhaps even more - than what one perceives through the gun smoke on the front lines of pioneering historiographical research.

The contributions to this forum come as a great relief. The participants do not gather tearfully at the bedside of a moribund century. They register an unavoidable and entirely unsurprising - even welcome - shift of interests and resources toward more recent periods. Their concern about a certain loss of the century's erstwhile sparkle, especially in the eyes of younger generations of scholars, never amounts here to panic and alarm. More than one author assures us that the field is "vibrant" - a potent consolation for those who prefer high-energy hustle to the long-wave calm that, to overstate a bit Suzanne Marchand's memorable argument, was a token of the nineteenth century's inner strength. The contributors spot minor deficiencies and suggest sensible and practical remedies. None of them despairs. They all behave extremely civilly. There seems to be widespread agreement that the nineteenth century can make better claims on our attention, even with regard to staff positions and funding, than earlier epochs. It seems to be more of a "prehistory of the present" than the eighteenth century was: a fountainhead of legacies ranging from social theory (Lloyd Kramer) to the toxic delusions of ethnic nationalism (Pieter Judson). Even so, none of the contributors suggests that resources might be rechanneled to the nineteenth century from fields of history that are less relevant and innovative; in the German context, medieval studies, traditionally pampered and untouchable, comes to mind.

Finally, all the essays assure us that the field is basically on the right track. Only Sebastian Conrad adopts a welcome polemical fervor and conjures up a new vision of the nineteenth century centered on the "master trope" of colonialism. Scholars dizzy from the serpentine succession of paradigms and "turns" need not have to be persuaded at first sight by his "post-postcolonial framework" to find such boldness welcome and helpful. The debate only progresses when truly new ideas are being suggested that go beyond the pious commitment to take on board global approaches. Who would object to that nowadays? ${ }^{4}$

Before moving on to some more specific thoughts inspired by the essays, let me briefly say a few words about external pressures and constraints. Karen Hagemann rightly urges us not to "follow the power of the market and every fashion in the discipline." Pressures to do so are different in each national academic arena, and I can only speak from my limited German experience. The great majority of our $\mathrm{PhD}$ students do not pursue university careers. Some try to do so after completion of their doctorate and fail. Many others never aim for academic advancement. For them, there is no question of a Habilitation, or a second book, and their choice of topic for the doctoral dissertation is not governed primarily by strategic calculations. The job market is simply too large and too fragmented to be predictable. If one wants to work in a museum, in the media, or in academic and cultural management, the topic of one's dissertation is of secondary importance. Nothing militates against working on a nineteenth-century subject.

For the more adventurous, or perhaps the more bookish, who see their future inside the academy, it is next to impossible to establish themselves as experts on the nineteenth century.

\footnotetext{
${ }^{4}$ On the strange lack of resistance to global studies, see Jürgen Osterhammel, "Global History," in Debating New Approaches to History, ed. Peter Burke and Marek Tamm (London: Bloomsbury, 2018), 21-47.
} 
Only the biggest history departments offer specialized chairs in the history of the nineteenth century-German, European, or global. The safest strategy continues to be not to put all one's eggs into one basket and thus to demonstrate competence in both the nineteenth and twentieth centuries by writing a monograph on each. The mysterious label Neuere and Neueste Geschichte (modern and contemporary History) is still commonly attached to professorships at German universities, especially in small departments, and it is only slowly fading from use. It is usually taken to mean "history since c. 1800." The popularity and institutional proliferation of Zeitgeschichte (contemporary history) notwithstanding, the incumbent of the chair in Neuere and Neueste Geschichte usually contributes to the teaching of twentieth-century history, especially if the occupant of the chair in Zeitgeschichte defines her or his responsibility as beginning in 1945. Surveying the German academic scene leads to the conclusion that nineteenth-century history is not losing senior positions because it never had them. At the same time, the reluctance of mainstream early modern historians, often firmly anchored in the sixteenth and seventeenth centuries, to transcend the conventional caesura of 1800 , leaves ample room for historians of "high" or "late" modernity.

The danger of pitiful nineteenth-century studies being crushed between adjacent subdisciplinary imperialisms is fairly remote, unless a dramatic contraction of the academic labor market triggers a struggle for survival. The nineteenth century will always figure, to some extent, in teaching transepochal longue-durée or comparative topics, even if only in masters' programs. This comes at the expense of many canonical topics of old. Still, one can fit the revolutions of 1848/1849 into a course on modern political breakdowns, see the French Revolution in a transatlantic or "Imperial Meridian" perspective, or place industrialization within a "Great Divergence" framework - while aware of the last's theoretical and empirical shortcomings.

Losing a century does not necessarily mean that it drifts away unmoored on the ocean of history. More pragmatically, it means that its shape becomes ever more difficult to determine. This is true, first of all, of its temporal shape. My own outsider's (or "ethnographic") inspection of the nineteenth century baffled a few readers and reviewers because I refused to place demarcating dates on the century. When, people wondered, did it "really" begin and end? The starkly nominalist answer was not to everyone's taste. Sometimes it is convenient to begin a story in the 1760s with the "age of revolutions" and to bring it to a close somewhere in the 1920s. Sometimes a very short rump century (c. 1830 to 1880), as mentioned by David Blackbourn, is preferable; Richard Evans's superb new history of Europe is anchored in this kind of "Victorian" core. ${ }^{5}$ Such a century with frayed and amoeba-like elastic boundaries undermines the very idea of a parade of equally extensive slices of time. That is precisely the intention.

Two other issues are much more interesting: the internal structure of a chronological century, and its place within the longue durée. On both issues, the forum provides helpful insights. Alexander Martin points out that, for Russia and the tsarist empire, 1861 was a much more important turning point than any date around the calendric end of centuries; it even resulted in two different historiographies. ${ }^{6}$ Closer inspection will yield similar

\footnotetext{
${ }^{5}$ Richard J. Evans, The Pursuit of Power: Europe 1815-1914 (London: Allen Lane, 2016).

${ }^{6}$ The turning point has lately been somewhat neglected in debates about periodization. By contrast, see Andrew Abbott, Time Matters: On Theory and Method (Chicago, IL: University of Chicago Press, 2001), 240-60; Dieter Langewiesche, “'Zeitwende'-Eine Grundfigur neuzeitlichen Geschichtsdenkens:
} 
results for other European — and, even more so, for extra-European-countries. In large parts of the world, the onset of colonial conquest cut the century into two halves. Debates about periodization are rarely a waste of time, as some scholars maintain. But one should not get bogged down in fixing centuries temporally. Shorter periods, if flexibly handled, can be more sensible. A recent model of a virtuoso use of overlapping periods — of vastly differing lengths - is Anthony Reid's magisterial A History of Southeast Asia, which is not just useful for historians of Asia. ${ }^{7}$

The question of how the conventional nineteenth century fits into longer rhythms and sequences is addressed, more or less explicitly, in all the contributions. They do not recommend that we all now rush into macrohistory and try to impress those in the lay public who constantly expect big answers to purportedly big questions. Those infatuated with fashionable "Big History" should not lose sight of the truisms and banalities that its protagonists routinely utter about the nineteenth century. ${ }^{8}$ But we should feel encouraged to adopt a broader view by taking the example, for instance, of the British political scientists, Barry Buzan and George Lawson, who, with the innocent exuberance of lay connoisseurs of historical literature, rediscovered the nineteenth century as the site of a bundle of world historical transformations. ${ }^{9}$ To take the measure of such profound changes requires harking back to the early modern period - something that comes naturally to Pieter Judson in a Habsburg framework and that is a matter of course, to cite just one other example, for historians of (European) empire. Provincializing the French Revolution and being less dazzled by Napoleon's mega-show-which will be exhaustively commemorated in his anniversary year, 2019might help to flatten a threshold that still keeps many early modernists and nineteenthcentury specialists in separate camps. Overarching concepts such the Anthropocene (mentioned by Brophy) bridge the ages. They deserve serious consideration, especially when they encompass the environment, a vital topic missing from the contributions to this forum. In fact, the most glaring absence among the general surveys of Europe in the nineteenth century is a comprehensive work on environmental history. ${ }^{10}$

The contributors to this forum highlight different levels of analysis that are equally relevant and legitimate. Simone Lässig shows how a seemingly narrow and peripheral field can illuminate a far larger canvas. Others reflect briefly on devising new national histories as histories of entanglement. As a global historian, I welcome this tendency, while sympathizing with Alex Chase-Levenson's admonition that we not forget those who remained "relatively

\footnotetext{
Richard Koebner im Vergleich mit Francis Fukuyama und Eric Hobsbawm," in Zeitwende: Geschichtsdenken heute, ed. Dieter Langewiesche (Göttingen: Vandenhoeck \& Ruprecht, 2008), 41-55; Karsten Fischer, ed., Neustart des Weltlaufs? Fiktion und Faszination der Zeitenwende (Frankfurt/Main: Suhrkamp, 1999).

${ }^{7}$ Anthony Reid, A History of Southeast Asia: Critical Crossroads (Chichester: Wiley-Blackwell, 2015).

${ }^{8}$ See, e.g., David Christian, Maps of Time: An Introduction to Big History (Berkeley: University of California Press, 2004), 406-39.

${ }^{9}$ Barry Buzan and George Lawson, The Global Transformation: History, Modernity and the Making of International Relations (Cambridge: Cambridge University Press, 2015). See also Bo Stråth and Peter Wagner, European Modernity: A Global Approach (London: Bloomsbury, 2017). For a completely different historical sociology of Europe, see Michael Mann, The Sources of Social Power, vol. 2: The Rise of Classes and Nation-States, 1760-1914 (Cambridge: Cambridge University Press, 1993).

${ }^{10}$ I am thinking of a counterpart, largely limited to Europe, to John R. McNeill, Something New under the Sun: An Environmental History of the Twentieth-Century World (New York: Norton, 2000). For a brief introduction, see Franz-Josef Brüggemeier, Schranken der Natur: Umwelt, Gesellschaft, Experimente. 1750 bis heute (Essen: Klartext, 2014), 19-163.
} 
untouched by global connections." Relative is the crucial word here, because globality is always a matter of degree. Perhaps wisely, none of the Forum contributors discusses ways in which nineteenth-century European history as a whole has been, and can be, conceptualized and narrated — wisely, because general histories, often written for the textbook market, tend to disappoint. ${ }^{11}$ Many years ago, a distinguished British reviewer had this to say about John M. Merriman's bulky History of Modern Europe: From the Renaissance to the Present (1996): "There is nothing in this book to cause offence, but there is nothing to generate excitement either." 12 When Marchand meets people who find the nineteenth century boring, they might have been sent to sleep by the tepid encyclopaedism of this kind of literature. ${ }^{13}$

What might characterize exciting histories of Europe in the nineteenth century? They should be topical histories of something rather than inventories of everything-for example, histories of military affairs, here elegantly discussed by Roger Chickering, whose essay is a model for still unwritten essays on a number of similar topics. ${ }^{14}$ They should be unobtrusively comparativist - despite the fact that comparison seems to be out of favor nowadays, for no other reason than the myth that it is irreconcilable with the analysis of connectivity. They would and should not allow human beings to vanish behind big structures and large processes; at the same time, they should not be content with mere pointillism and the telling of anecdotes. In geographic terms, exciting histories of Europe should cover more than the triangle formed by Edinburgh, Toulouse, and Vienna. They should not neglect "lost corners" and lost causes, and they must not shirk the issue of relative backwardness, often considered taboo by critics of modernization theory. In temporal terms, a short cross section will do, perhaps nothing longer than a decade. ${ }^{15}$

Did I have models in mind while drawing up this laundry list? Yes, but let me conclude by mentioning just one: Richard Stites's The Four Horsemen, a narrative history of revolutions in Spain, Naples, Greece, and Russia during the 1820 s — and much more. ${ }^{16}$

\footnotetext{
${ }^{11}$ See Jürgen Osterhammel, "Europamodelle und imperiale Kontexte," Journal of Modern European History 2, no. 2 (2004): 157-81.

${ }^{12}$ Tim Blanning, "Gibbon Goes East: Three Contrasting Approaches to the History of Europe," Times Literary Supplement (Dec. 20, 1996), 4. Blanning did, in fact, take offense at Norman Davies's Europe: A History (Oxford: Oxford University Press 1996). For an even stronger opinion on that widely read book, see Tony Judt, When the Facts Change: Essays 1995-2010 (New York: Penguin, 2015), 47-64.

${ }^{13}$ Of course, a few works are exempt from such a harsh verdict. See, among more recent syntheses, Evans, Pursuit of Power; Robert Gildea, Barricades and Borders: Europe 1800-1914, 3rd ed. (Oxford: Oxford University Press, 2003); for an excellent study that deals with only one half of the century, see Jonathan Sperber, Revolutionary Europe, 1780-1850, 2nd ed. (Harlow: Longman, 2017).

${ }^{14}$ For a list of possible topics, see the chapter headings in Stefan Berger, ed., A Companion to NineteenthCentury Europe, 1789-1914 (Malden, MA: Blackwell, 2006).

${ }^{15}$ Jan Vansina, "Towards a History of Lost Corners in the World," Economic History Review 35, no. 2 (1982): 165-78.

${ }^{16}$ Richard Stites, The Four Horsemen: Riding to Liberty in Post-Napoleonic Europe (Oxford: Oxford University Press, 2014).
} 


\section{Andrew Zimmerman (George Washington University)}

$\mathrm{T}$ HE participants in this forum identify a number of themes that our present moment shares with the nineteenth century - partly to highlight the relevance of that century for our own century, partly to decry what some of them see as an insufficient interest in that century on the part of university students and academic specialists in European history. Most broadly, as James Brophy writes, the nineteenth century was a "conceptual crucible of political modernity." The problem, though, is that the things we understand by conceptual, crucible, and modernity continue to change, as they always have. Like a few of the participants, I remain skeptical that there is, in fact, a crisis in nineteenth-century European history, but I am convinced of the value of thinking as if there were such a crisis. In what follows, I discuss the themes raised by the individual contributors and offer a few additional themes that I think also deserve consideration. My aim is to redirect a discussion that verges, in some of the contributions, on a jeremiad into a consideration of how we doctors might heal ourselves.

Karen Hagemann reminds us that the structures of gender and sexuality within and against which we struggle today gained something like their present form in the nineteenth century. We might also connect present-day feminist politics to those of the nineteenth century. With the \#metoo movement, feminists have won major victories through militant, "unruly" action, braving the condemnation of many to strike a major blow against sexual harassment and the pervasive forms of patriarchy that both enable it and thrive on it. Feminists are out on the streets again, more Emmeline Pankhurst than "leaning in." Also fundamental to our moment is the courageous work of trans people and their allies. These movements against heteronormativity hark back to many moments, and some of them are in the nineteenth century.

Hagemann argues persuasively that we can have little hope for expanding interest in the study of the nineteenth century if mainstream historians continue to dismiss the study of categories of difference, including gender, as something for specialists. The "prominent stories of prominent men," to borrow a phrase from the Velvet Underground, will always attract some students, but they have limited scholarly value and are seriously out of touch with the concerns of an ever more diverse student body and profession. To reject all this as "postmodernism" or as "political correctness" indicates, in this very terminology, not sage disapproval but uninformed disregard. Such a dismissive attitude toward the most innovative scholarly and political tendencies of our time is unlikely to draw new scholars to the study of the nineteenth, or any other, century.

Simone Lässig, in her contribution, makes clear how revelatory the study of so-called minority populations - in her case Jews, but we might say the same of Afro Europeans and many other groups - are for the study of the nineteenth century precisely when we liberate them from narratives of assimilation to a majority culture. She expresses forcefully an argument that Hagemann also makes about the marginalization of gender in mainstream history, nineteenth-century and otherwise: "The problem ... is not that a particular century is disappearing but rather that a boundary between a subfield of European history and the field of European history in general is not disappearing ...."

Military history is not, Roger Chickering demonstrates, suffering a decline of interest in the nineteenth century, although it is worth recalling that military history, as a whole, understands itself to be in crisis. I work on what could be defined as nineteenth-century military 
history, and, based on that experience, I think it would be worth treating revolutions as being of equal importance with war in the field that we now call military history. The nineteenth century was, after all, a century of revolutions. Nineteenth-century militaries certainly recognized domestic revolution as one of their enemies, and tactical manuals often reflected this. The death toll of the Paris Commune matches that of the bloodiest battles of the American Civil War. Carl von Clausewitz's theory of war develops a theory of absolute war less fully than it does a theory of Volkskrieg, a blending of war and revolution that emerged from the French Revolution and that continues to this day. This was a strand of Clausewitz's theory that leftist readers, from German American Civil War General Franz Sigel to Leon Trotsky to Guy Debord, have highlighted. Leftists were the earliest and, according to Hew Strachan's insightful account, best readers of Clausewitz, before Helmut von Moltke repurposed On War as a theory more flattering to state militaries than to revolutionaries. ${ }^{1}$

We live in an era again obsessed with political and social revolution, from Tahrir Square to the direct confrontations with the state and capital in the Dakota Access Pipeline protests, to the film $V$ is for Vendetta and the television series Mr. Robot. It is thus surprising that there is so little discussion of revolution in the contributions to this forum. Alexander Martin suggests that we explore nineteenth-century Russia to understand the pathologies of political violence. We should also follow the lead of Claudia Verhoeven, who seeks to understand the often arcane and violent movements of the nineteenth-century Russian underground in their own terms, as they sought - fabulous and imperfect like everybody - to transform the world around them. ${ }^{2}$ Lloyd Kramer suggests that 1848 and the Commune receive less interest because "nobody believes that such revolutions are possible in modern societies." But such universal proclamations are always suspect, and my name would be just one on a long list of scholars whose own existence demonstrates the empirical weakness of Kramer's assertion. There is no lack of intellectual interest in revolution. Kristen Ross's recent book on the Commune highlighted the importance of that nineteenth-century event to our day, as did, in its own way, Peter Watkins's splendid film La Commune (Paris, 1871) (2000). These works suggest approaches to revolution that academic historians of the nineteenth century would do well to follow. ${ }^{3}$

Globalization looms large, of course, in topics of present-day relevance on which we nineteenth-centuryists have much to offer. David Blackbourn, both in his piece for this forum and in his current research, makes a very strong case for the related theme of migration as a central theme of nineteenth-century history that is of tremendous relevance to our present moment. Pieter Judson and Alex Chase-Levenson both point out that the study of the global can often make arbitrary distinctions between the local and the global, making

\footnotetext{
${ }^{1}$ Carl von Clausewitz, Vom Kriege, 5th ed. (Berlin: Ferdinand Dümmler, 1905); Hew Strachan, Clausewitz's On War: A Biography (New York: Atlantic Monthly Press, 2007).

${ }^{2}$ See Claudia Verhoeven, The Odd Man Karakozov: Imperial Russia, Modernity, and the Birth of Terrorism (Ithaca, NY: Cornell University Press, 2009); idem, "Time of Terror, Terror of Time: On the Impatience of Russian Revolutionary Terrorism (Early 1860s_Early 1880s)," Jahrbücher für Geschichte Osteuropas 58, no. 2 (2010): 254-73; idem, "Wormholes in Russian History: Events 'Outside of Time' (Featuring Malevich, Morozov, and Mayakovsky)," in Breaking up Time: Negotiating the Borders between Present, Past and Future, ed. Chris Lorenz and Berber Bevernage (Göttingen: Vandenhoeck \& Ruprecht, 2013), 109-23.

${ }^{3}$ Kristin Ross, Communal Luxury: The Political Imaginary of the Paris Commune (London: Verso, 2015); La Commune (Paris, 1871), directed by Peter Watkins, 2000. See also John Merriman, Massacre: The Life and Death of the Paris Commune (New York: Basic Books, 2014).
} 
that which is local suddenly uninteresting or passé. I would add that these global histories too often reproduce the local/global distinction, so that they remain histories of a particular nation-just abroad. And if this global turn means, as Judson points out, that there will fewer positions in European history, so be it. Provincializing Europe, to speak in shorthand, has been the most important, most welcome, and most refreshing development in European history since, perhaps, the emergence of social history.

Sebastian Conrad alerts us to a real problem in conceiving of transnational studies as the study of globalization rather than of imperialism and colonialism. He points to the apologetic, ideological function that certain conceptions of globalization play, most prominently in the work of Niall Ferguson. ${ }^{4}$ Conrad's point also applies to the breezy litany of things that are always getting "connected," sometimes "entangled," in our favorite century. The house of history has many rooms, and it should be ruled by no political orthodoxy. But since we are talking about which rooms are likely to appeal to new scholars in the present moment, we should note that those who came of age after the 1999 Battle of Seattle are likely to have less interest in Fergusonian celebrations of "Anglobalization" than in the kind of critical imperial and colonial history that Conrad and others pursue. It is no wonder that, as Conrad notes, the histories of imperialism and colonialism have not experienced the kind of decline that other subfields of nineteenth-century European history have. They are, on the contrary, flourishing, and they have been for decades.

I agree with James Brophy that it is very odd indeed that academic scholars of the nineteenth century do not give more attention to the variety of democratic socialisms that flourished in the nineteenth century, although much of Geoff Eley's work and Jens-Uwe Guettel's current research are just two exceptions that should be mentioned in this context. ${ }^{5}$ Socialism is once again a popular movement in the United States and Europe. As in the nineteenth century, it raises a specific set of demands and keeps talk of systemic change in the background. In the United States today, these demands include the fifteendollar minimum wage, single-payer health care, and free college tuition; in nineteenthcentury Europe, these demands similarly did not call for state planning and control but rather for a series of measures to free working people from the economic and political control of the wealthy. ${ }^{6}$ Neoliberal "third-way" parties in Europe and the United States find themselves facing leftist rebellions. Most recently, the leftwing Momentum movement has braved scurrilous accusations to challenge the Blairism of the Parliamentary Labour Party, and a similar movement challenges the old guard of the Democratic Party in the United States. Like revolution, socialism is a topic that appeals to undergraduate and graduate students.

The old "totalitarian" model, revived in the 1990s, still lingers in our academic groves and stymies the ability of many scholars to study socialism or revolution as anything but a

\footnotetext{
${ }^{4}$ Niall Ferguson, Empire: The Rise and Demise of the British World Order and the Lessons for Global Power (New York: Basic Books, 2003).

${ }^{5}$ Geoff Eley, Forging Democracy: The History of the Left in Europe, 1850-2000 (New York: Oxford University Press, 2002); Jens-Uwe Guettel, "The Myth of the Pro-Colonialist SPD: German Social Democracy and Imperialism before World War I," Central European History 45, no. 3 (2012): 452-84; idem, "Radical Democracy in the German Empire, 1871-1918" (work in progress).

${ }^{6}$ The most famous list is that given at the end of the second section of Karl Marx and Friedrich Engels's Communist Manifesto of 1848. For these demands in action, see, e.g., Johann Philipp Becker and Christian Essellen, Geschichte der süddeutschen Mai-Revolution (Geneva: Gottfried Becker, 1849).
} 
deviation from a normative and idealized liberalism. Now as then, writers within this hegemonic paradigm lump together left and right to present themselves as representatives of a sensible middle. Today the term populism is more common than totalitarianism. "Populism" has allowed commentators in major US newspapers, for example, to lump Mexican President Andrés Manuel López Obrador with US President Donald Trump-the better to demonize left deviations from a liberalism that flatters itself as a virtuous middle, even while sharing far more with the right than it cares to admit. ${ }^{7}$

An odd absence from the forum, and perhaps an odd absence from much of the field of nineteenth-century European history, is the topic of slavery and emancipation. After all, the shift from bonded to wage and contract labor has long been recognized as one of the most fundamental events in human history, and its peak moments were in the nineteenth century. For historians of the Americas, there is no question more central today than that nineteenthcentury question. We ask about how slavery functioned as part of capitalist relations of production; about how enslaved people created lives, communities, and polities; about how they overthrew slavery; about the various post-emancipation labor coercive regimes that emerged in the wake of enslavement. Alison Frank Johnson's recent work provides a good example to nineteenth-century Europeanists interested in tackling this question, and the literature on British abolitionism remains, of course, robust. ${ }^{8}$

Even more surprising by its near absence, especially among scholars of Central and Eastern Europe, is the question of serfdom, that other form of unfree labor whose histories of resistance, emancipation, and post-emancipation labor coercive regimes are as relevant to our own present moment. The history of bondage and emancipation is also central to the political lives of many of our students and thus of potential nineteenth-century scholars. The Black Lives Matter movement has made slavery and emancipation central, not as phenomena of the past but rather as struggles of our present moment. Black Lives Matter has highlighted how slavery lingers on, with law enforcement as an extension of the slave patrol, and slavery itself moved from the plantation to the prison. Meantime, activists in Jamaica and in the United States call for reparations for enslavement. Confederate statues are coming down. Emancipation can no longer be celebrated as a past achievement: it must be fought for in the present so that it might be achieved in the future. That is to say: slavery and emancipation are living history. Yet, there is little mention of either in the forum. Similarly, none of the contributions gives extended attention to race as a topic of critical analysis.

Another missing topic that might draw new generations of scholars into nineteenthcentury European history is liberalism-not triumphalist histories of liberalism, but critical ones. In our era, liberalism has doffed its silk hat again, screwed in its monocle, and learned to harrumph. Its hatred for the mob, its faith in rule by upstanding property

\footnotetext{
${ }^{7}$ See, e.g., Azam Ahmed, "The Firebrand Leftist Far Ahead in Mexico's Presidential Polls," New York Times, June 29, 2018; “Mexico's Could-be President is a lot like Trump. That doesn't mean they'd get along" (editorial), Washington Post, June 17, 2018.

${ }^{8}$ Alison Frank, "The Children of the Desert and the Laws of the Sea: Austria, Great Britain, the Ottoman Empire, and the Mediterranean Slave Trade in the Nineteenth Century," American Historical Review 117, no. 2 (2012): 410-44. Two of the many recent important works on British anti-slavery are Christopher Leslie Brown, Moral Capital: Foundations of British Abolitionism (Chapel Hill: University of North Carolina Press, 2006); Julie L. Holcomb, Moral Commerce: Quakers and the Transatlantic Boycott of the Slave Labor Economy (Ithaca, NY: Cornell University Press, 2016).
} 
owners, have returned in all their gilded, nineteenth-century splendor. One manifestation of this is the common belief, easily disprovable by exit polls, that Donald Trump was elected by the mob, the Pöbel. "Deserving" no longer, the poor are now a legitimate object of liberal contempt. We also see this liberal hatred of the poor in invocations of the "creative class" to mask the injustices of gentrification and displacement, as well as in the common refrain that impoverished workers need to "adapt" to new "realities." The economics of all this has roots in the 1990s and even earlier. It was then that liberalism abandoned the welfare capitalism it had advocated during the short twentieth century and began trumpeting what it euphemizes as "the market." Most call that neoliberalism, but we nineteenth-century specialists must surely recognize this as paleoliberalism, the liberalism of Samuel Smiles and the workhouse.

Nineteenth-century Europe was, of course, home to one of the great critical students of liberalism, Karl Marx. Jonathan Sperber's marvelous biography recently returned him to the nineteenth century and, in doing so, also made him newly relevant to our own century. ${ }^{9}$ We see Marx as one of Sperber's Rhineland radicals, then as a London exile, as marked by error and vanity as any thinking creature, working out sophisticated analyses and savvy political strategies on a changing social and political terrain. He is no dispenser of abstract formulae, no dogmatic seer, but a flesh-and-blood human being living in, and against, an unjust world. What better model for students and scholars in the twenty-first century, and who more rooted in the nineteenth century?

The critical history of liberalism was the central project of Michel Foucault, the scholar whose work on nineteenth-century Europe continues to inform and inspire like no other specialist of the era. His work on discipline and on sexuality, on power and knowledge, has enlivened not just academic nineteenth-century European history but our entire intellectual environment. It was surprising to find only a single mention of Foucault in this forum, and even more surprising that it was a pronouncement, in Suzanne Marchand's contribution, that his work has reached "the end of [its] usefulness." One can legitimately disagree about any author, but I wonder if Marchand's own essay does not make very clear the ongoing, maybe even increasing, importance of precisely Foucault. To take just one example: Marchand tells us that amazon.com, like many other phenomena, authors, and inventions, should be "celebrated." But it is hard to imagine the laudatio as a likely genre for new academic knowledge. Indeed, a Foucauldian analysis of surveillance and discipline in amazon.com's infamous warehouses strikes me as a far more likely avenue for nineteenth-century inspired scholarship than a celebration of this company as, we are told, a child of the nineteenth-century penny post. Meanwhile, scholars in other fieldsWendy Brown and Domenico Losurdo, for example - are producing important and critical studies of liberalism (neo- and paleo-); too few historians, to our discredit, have engaged with this work. ${ }^{10}$

The numbers may not look so good. But I do not think it is the students, with their supposed naiveté, impatient minds, Twitter, etc., who are to blame. It never is, of course; it

9Jonathan Sperber, Karl Marx: A Nineteenth-Century Life (New York: Liveright, 2013); idem, Rhineland Radicals: The Democratic Movement and the Revolution of 1848-1849 (Princeton, NJ: Princeton University Press, 1991).

${ }^{10}$ Wendy Brown, Undoing the Demos: Neoliberalism's Stealth Revolution (New York: Zone Books, 2015); Domenico Losurdo, Liberalism: A Counter-History (London: Verso Books, 2011). 
never is the rising generation that is responsible for the wrecked world they inherit. The discipline of history always, necessarily, reflects its own intellectual and political conjuncture. David Blackbourn makes this point eloquently in his contribution to this forum. We are seeing a shift from a neoliberal conjuncture to a revolutionary one. I have cited \#metoo, transpositive feminism, Black Lives Matter, and the rapid growth of democratic socialism, and there are also many other movements. They are shaking our windows and rattling our walls, all for the good. I would encourage historians of nineteenth-century Europe not to get stuck in the past-in our case, buried in the rubble of the collapsing edifices of neoliberalism. We should replace the aestheticizing "the past is a foreign country" with William Faulkner's politicizing “The past is never dead. It's not even past."11

${ }^{11}$ William Faulkner, Requiem for a Nun (New York: Vintage International, 2012), 69. 